Portland State University

PDXScholar

1972

\title{
The women's liberation movement and identity change : an urban pilot study
}

Molly M. Doeneka

Portland State University

Follow this and additional works at: https://pdxscholar.library.pdx.edu/open_access_etds

Part of the Other Anthropology Commons, Social and Cultural Anthropology Commons, and the Sociology of Culture Commons

Let us know how access to this document benefits you.

\section{Recommended Citation}

Doeneka, Molly M., "The women's liberation movement and identity change : an urban pilot study" (1972). Dissertations and Theses. Paper 957.

https://doi.org/10.15760/etd.957

This Thesis is brought to you for free and open access. It has been accepted for inclusion in Dissertations and Theses by an authorized administrator of PDXScholar. Please contact us if we can make this document more accessible: pdxscholar@pdx.edu. 
AN ABSTRACT OF THE THESIS OF Molly M. Doenska for the Master of Arts in Anthropology presented November 22, 1972.

Title: The Women's Liberation Movement and Identify Chance: An Urban Filot Stuajy.

APPROVED BY MEMBERS OF THE THESIS COMMTTREE:

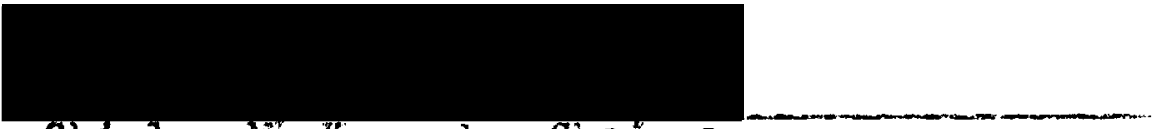

Shirley W. Kennedy, Chajrman

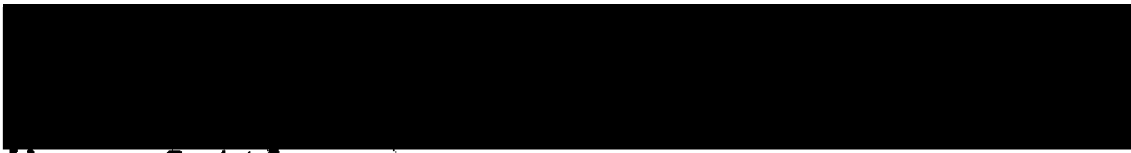

Wayne Suttien

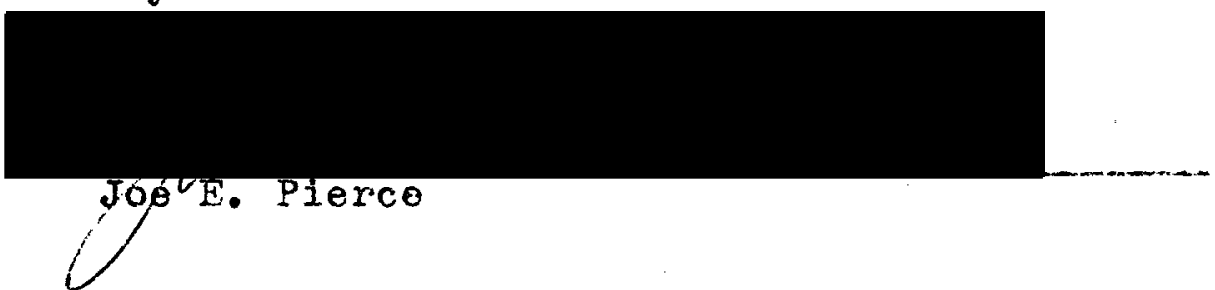

Ths purpose of this study was to cotermine if partici. pation in women's Liberation results in identity change in the individugl proticipants. As a pilot study, fi exarires the characteristic exporiences of a study group of ententyo six local participants and compares the fifects of thoir participation with a treosetical rodol of dentity change process ploposed by bard H. Coodenowg In Cooveratior in Change. Accoraing to this model tino process of iaentiry

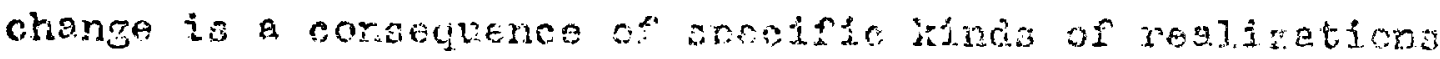


fostered by a series of definable stages winich aro: 1) achieving a desire for identity change, 2) making a comitment to change, 3) attaining an understanding of what needs to be charged (which involves regognizing the problems and solutions to achleving change), and 4 ) having the new ldentity accepted by others.

The research included an examination of avallable materials on Women's Liberation, the consultation of $\operatorname{son} \theta$ general literature on the status of women, personel participation in various Women's Movement activities, observam tion of individual participants and groups in action, the collection of in-depth interviow statements and blographles from a study group of twenty-six women who are Wonen's Liberation participants, and finally, a comparative study of the findings.

The comparative study involved an analysis of the interview information in light of the theoretteal model of idantity change. Spocifically analyzed were tho procoss Involved in facilitating identity change, and the actual. effects of participation on the women in the study group (as this relatod to iciontity chenge). A discussion is. presonted of the impomants' experiences axd how thay soe themseives since perticipation, and a dibcussion of somo of the aspects of public response to women's participation In Women's Liberetion activities.

The findings show that all of the women studiar $6 x-$. 
perionced identity chango in varying degrees; all have been subjected to new self-confrontation experiences; all made physical and/or psychological behavioral nodifications; all expertenced chenges in their categories of perception and their critais for evaluating their changed perceptions; and, all heve some understanding of what they want changed and how to achieve 1t. Tho most extensive identity changes occur in those who are most actively involved, in those who have had the most exposure to radical political activitios and those whose social circumstances are most favorably receptive to Women's Liberation. Individuals who are not extensively involved, who have conservative political and/or religious beckgrounds, and who are exposed to continued hostile or negative reception on the part of others to their activitios are blocked from achleving extensive identity change. In general, the experiences and behavior of the women in this study conforms to what is now known about women's participation in the movement and the genersl public's response to Women's Libarationiats.

The stuciy presentis a brtef history of the baciground of the movenert, a discussion of the theoretical model used, an account of the research mothodology, a series of sample portraits of women in the study, the data analysis, an application of the theoretical fromework to the dats, and a brief discussion of some genoral implications of the Women's Movemont as whole. This thesis shows that participation in the movemst produces identity change winich conformg to an anth- 
ropological model of 1dentity change process. 
THE WOHEN'S LIBERATION MOVENENT AND IDENIIIY CHANGE:

AN URBAN PILOT STUIY

by

MOLIY M. DOENEKA

A thosis submitted in partial fulfillmont of the requirements for the degree of

MASTER OF ARTS

in

ANTHROPOLOGY 
TO THE OFFICE OF GRADUATE STUDIES AND RESEARCH:

The members of the Committee approve the thesis of Molly Mo Doeneka presented November 22, 1972.
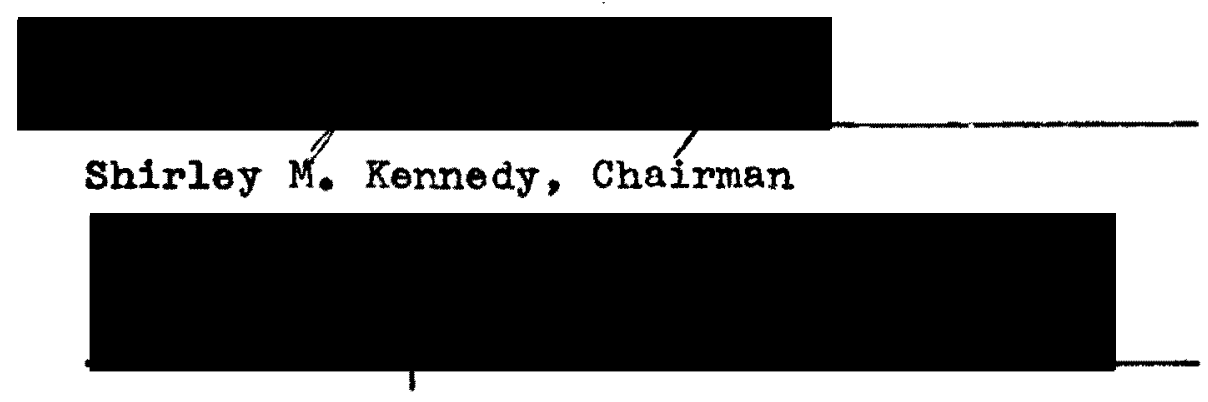

Varne Suttles

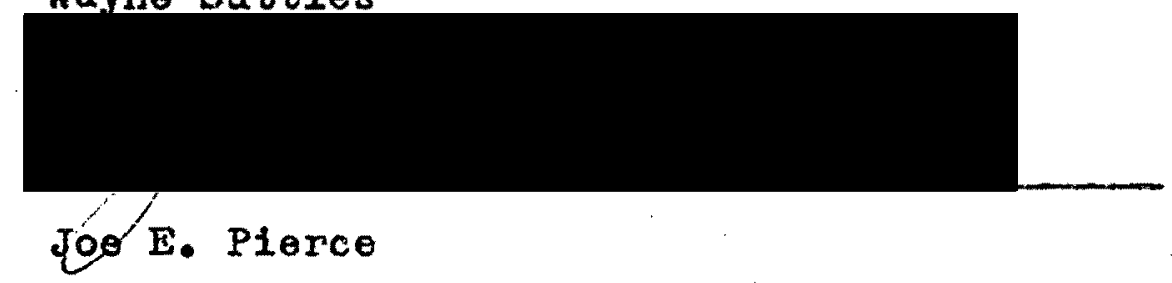

APPROVED:

Thomes Herman, Dopartmont of Anthropology

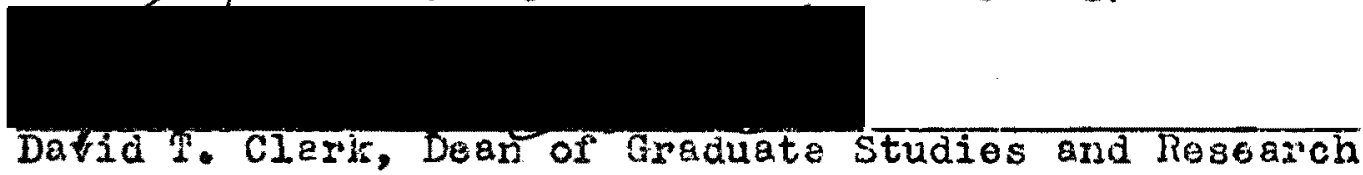




\section{PREFACE AND ACKNONLEDGEMENTS}

In the course of deliberation about the selection of Women's Liberation as a subject for research I became an active participant in the movement. As a participant observer I was not only an active member of the movement, but also what Ward Goodenough refers to as an "agent of change" (seo Chapter II). I do not foel that my boing a partic1pant and an organizer limited or hampered my ability to deal with the subject, but rather doepened my perception of the movement and enabled me to deal with the subject with a much more profound understanding. It remains for my department and for my readers to pass on mig objectivity of the subject.

In sddition, I wish to note there is no single Women's Liberation Movement as such. For every woman in the movement there exists a different idea of what the movement 1s. In spite of this it is possibla to form a composite of Ideas and find a body of adherents and label them "Women!s Liberationists," and to know further that they would concur" with the findings and agrea to beling part of this composite group.

It is nocossary to boar this in mind when considoring the movement as a whole in order not to be confused by the 
variations which occur within the movement.

Finally, I would like to say that the whole exper-

Lence of doing research on the topic of Women's Liberation has profoundly changed my life, if not in its external circumstances certain].y in my hoad. I have come to know many lovely women whom I would not otherwise had an opportunity to meet. Some of these women and I have worked together to develop snd teach a college course on the Women's Movement and in the process I had further opportunity to meet women as students who have contributed much to my understanding and development as a teacher.

I would ilke to give speclal thanks to Kathy, my daughters, and the other women with whom I live, who have held my hand during crisis periods and managed our household so I could work; to Ann Clarkson, Kathy West, and Barbara Vatter, with whom I worked to develop an introductory course on Women's Liberation and who helped team teach the first offering; to all of the women who agreed to be interviewed and share with me part of their 1:ves; to the members of my department who took the time to plow through all of my first proposals and endure my harassment; and especialiy to my for thesia advisor, Dr. Shirley M. Kenngdy, for hor time, patience, endurance, and help with whet has proven to bo most rewajding task. 
TABLE OF CONTENTS

PAGE

PREFACE AND ACKIYNLEDGEMENTS. . . . . . . . . 111

LIST OF TABLES. . . . . . . . . . . . . vili

INTRODUCTION. . . . . . . . . . . . . 1

CHA PTER

I THE WOMEN'S LIBERATION MOVEMENT . . . . . 8

Some Historical Antecedents. . . . 10

The Rise of Noo-Feminism . . . . 22

Footnotes. ........ 33

II TYEOFEICAL . . . . . . . . . 38

Identity Change. . . . . . . 39

Tho Essentials of Identity Change

The Desire for Identity Chango ... . 40

Reappraisal of Self

Evaluative Reappraisal

Cognitive Keappraisal.

Learning Ney Criterie for SelfReappraisal

Commitment to Change ....... 46

Undorstanding What Noods to be

Ghangad. .................. 48

Problems in Achlovemont,

Solutions to Problems of Achiovement 
Possession of the New Identity ... 54

Summary. . . . . . . . 55

Footnotes. ........... 57

III RESEARCH METHODOLOGY. . . . . . . . 59

Proliminary Study. . . . . . . 59

Secondary study. . . . . . . . 63

Research Data Acquisition. . . . . 65

Analysis Procedures. ....... 68

Sumnary . . . . . . . . 72

Footnotes........... 74

IV SELECTED INTEFVIEW REFORTS ....... 76

Tho Sample........... 76

Portraits From the Sample...... 83

Footnotes. ......... 107

v DATA ANALYSIS. ................... 108

Reasons for Participation...... 109

Specific Aspects of Chango . . . . 113

Degree of Personal Involvement . . . 117

Understanding of Changes: Problems and solutions............ i21

Professed Degree of Understanding About Content of New Roles...... 125

Perception of the Acceptance of Others ............ 129

Perception of Self Since Participation 131 
VI APPLICATION OF THEORETICAL FRAMEWORK TO DATA ................. 133

Informants' Desire for Identity Change 134

Informants' Commitment to Change . . 138

Informants' Understanding of What

Needs to be Changed. ........ 141

Informants' Participation Acceptance . 147

Summarization of Conciusions from the Study.............. 148

Discussion of the Implications of Women's Liberation........ 153

Footnotes............ 161

A LIST OF WORKS CONSULTED . . . . . . . . . 163 APPENDIX. . . . . . . . . . . . 173 
LIST OF TABLES

TABLE

PAGE

I Informants' (1-9) Statistical Character-

istics. . . . . . . . . . 79

II Informants' (10-18) Statistical Characteristics........... 80

III Informants' (19-26) Statistical

Characteriatics............ 81 


\section{INTRODUCTION}

During the past century the lives of women have undergone some profound changes which have been accompanied by various and numerable inconsistencies and contradictions. Modern industrial society, constantly undergoing rapid changes, has produced a multi-faceted culture, with constant and varied inter-culture contacts, consequently increasing the possibilities for cultural dizorientation. Traditional cultural values are frequently unsuited to changing social situations and they often prevent or deter individuals from pursuing courses of action which would be to their own or to society's best interests. On the other hand, if behaviors contrary to the traditional norms gre pursued, the individuals may be made to suffer guilt over violaticn of cultaral mores that no ronger serve any socially useful function. Then too, culturally defined behaviors are sometimes adhered to in the face of changing conditions without any necessarily conseious awareness of the discrepancies involved. The roles which cultural tradition dictates individuals play are sometimes $a_{i}$ odds with the reality of their actual situations and, as a result, frequentig produce either frustration in the pursuit of basic interests or an imbalance of privileges and obligations, or both. Furthar, charges in 
traditional cultural forms produce new situations and often create problems if they are not defined and accepted by the society. 1

The lives of women in today's world reflect all of these conditions, and one of the consequences of the cultural contradictions is the emergence of the Women's Liberation Movement.

All across the country women are coming together to participate in a variety of activities and to form groups which they label "Women's Liberation." These women seom to feel they need a new identity as women, an identity which will "liberate" them from their traditional roles as Adam's helpmate, Adam's wife, Adam's rib or whatever position puts them in a subordinate role to that of men. ${ }^{2}$

The most common theme which appears in the stated aims of the participants is the demand for equal opportunity of lifo chances and a change in the traditionsl status of women. 3 This idea appears to unify Women's Liberation groups throughout the country regardless of what their organizational work consists or what their specific. goals or purpose may be. These groups, both large and smail, are attempting to gain a new identity for women which some hope will provide them with the same rights and privileges that are enjojed by male members of this society, and which some hope will produce an Endrogenous society (that is, one in which the usual distinctions between men 
and women produced by their sex-role stereotyping are eliminated or blended) thus allowing both men and women to participate in a broader range of behaviors and roles. 4

Although there exists at present voluminous materials of recent publication on the subject of women and the Women's Liberation Movement in the United States (and elsewhere), there is no specific anthropological study as yet on the characteristic features of Movement participants. The present interest displayed on the part of the gensral public and in the nows media, as well as the proliferation of college courses dealing with the subject seems to warrant an extensive study of women's participation in Women's Liberation. In addition, the movement, as a current cultural phenomenon, cuts across class groupings to encompass women from a variety of socio-economic and ethnic sub-groups, consequently a study of their participation seems to be of special interest to anthropology. Moreover, a study of the movement suens important because its aims appear directed towards total cultural change and if completely realized would affect the lives of everyone.

The following is a study of the Women's Liberation Movement from the perspective of identity change, with the hope of making a contribution to anthropological studies relating to the dynamics of social change. 5 This is a pilot study of the characteriatic experiences of local participarts in the movement to determine if participation results 
in identity change, that is, if the activities of the movement participants are consonant with anthropological models of identity change process.

The particular model of identity change process, that is, the theoretical framework adopted, is taken from Ward Goodenough's model of directed identity change suggested for use by applied anthropologists in working with community development. 6 Goodenough maintains that individual lifehistories are marked by a series of identity chenges and these identity changes involve a number of necessary conditions: 1) achieving a desire for identity change; 2) making a comitment to change; 3) attaining an understanding of what needs to be changed (that is, what specific aspects of their lives they think should be changed), as well as recognizing the problems of achieving change and the solutions to these problems; and 4) having the new identity accepted by others.?

In this study I utilize Goodenough's theoretical framework to examine the features of participation among movement women and the kinds of experiences involved in their participation as they relate to Goodenough's variables. That is, I analyze the process involved in facilitating identity charige in participants of the movement in terms of their commitment and their understanding of what they want changed, as well as how they seo themselves in their present roles. There is also an examination of some 
of the characteristic features of the general public's response to women's participation in the movement.

The following chapters contain a short general history of the Women's Liberation Movement as necessary background information to the study, an extended discussion of the theoretical framework, an account of the research done and the methodology used, a description of the informants statistical characteristics and some sample protraits, the detailed rese日rch findings, and finally, an analys is and discussion of the findings in light of the thooretical framework and the conclusions drawn from the study presented in summary. Footnotes to each section are to be found following the individual sections. 


\section{FOOTNOTES}

\section{INTRODUCTION}

${ }^{1}$ For further elaboration of the cultural contradictions and its effects on sex-roles see Mirra Komarovsky, "Cultural Contradictions and Sex Roles," in American Journal of Sociology, Vol. 52, No. 3 (Nov. 1946), 184-189.

2An interesting commentary on the "Adam" positions as sumed by women can be found in an article by David $C$. McClelland, "Wanted: a New Self-Image for Women," in The Woman in America, edited by $R$. J. Iifton, (Boston: Be acon Pross, 1964), 173-192.

3Equal opportunity of $11 \mathrm{fe}$ chances is considered here as the public domain. Women do not enjoy the same "life chances" that men do in this regard in that they do not have equal access to the same economic opportunities as do men. For example, woman, es well as other minorities, congtitute the majority of wage-earners in this society; college educated women earn on the average only half as much as men with eighth grado educations; positions of power are held, in the main, by men; and positions of high status are dominated by men. All of these situations are not only related to the fact that traditionally the "woman's place" hes been in the home, but also because as women's treditional social role in the home becomes less fulfilling or socially significant their participation in the public domain increases in importance as a means to self-fulfillment. However, the public domain is "masculinized;" that is, employment patterns of hiring ard advancement are derived from mesculine life styles and masculine qualities (0.8., aggressiveness, dominance, competitiveness) are those things moat highly rewarded. Tho socially approved characteristics for women, on the other hana, (such as nurturance, passivity, concern for Interpersonal relations, interest in maintsining order and stabjitity) are devalued in the public sphere and this restricts women's opportunity for self-itulfjilment. Consequently women do not enfoy (as a general situation) equal opportunity of life chances with men.

Further studies on the economic as well as the behavioral aspects of women's social situation can be found in articles by the following writers in the biblography: Judith Bardwick, Bom and Bom, David Maclelland, Mart la M. Hughes, Joan Jordan, Gunnar Fyrdal. Alice Fossi, and Esther peterson, arone others. 
4According to Carolyn Heilbrun's definftion of androgenous, in "The Masculine Wilderness of the American Novel," in Saturday Review, Jan. 29, 1972, p. 41, "It is an ideal which allows full humanity to a human being without confining him within the conventional expectations for his sex."

5According to Homer Barnett, Innovation: The Basis of Cultural Change, (Now York: MeGraw-Hill, 1953), "a stuay of culture change takes us beyond the appearance of a now idea into a consideration of its acceptance and rejection, $(p$. 291), and further, "all cultural changes are initiated by individuals" (p.39), therefore on understanding of the offects of the Women's Iiberation Novement in terms of the dynamics of social change must begin with an analysis of the motivation of its individual participants.

6Ward Hunt Goodenough, Cooperation in Change, (New York: Russell Sage Foundation, 1963), 215-25I. Materials detailing the various aspects of identity change process are dealt with by a number of psychologists, sociologists, and anthropologists. The following authors may be referred to if the reader wishes to explore different presentations and perspectives in identity change process: 1) H. S. Becker and A. L. Strauss, "Eareers Personality, and Adult Socialization," The American Journal of Sociology, Vol. IXII, Nov., 1956: 253-263: 2) E. H. Erikson, "The Problem of Ego Identity," Psychological Issues, Identity and the Life Cycle, 1:101-66; 3) W. J. Goode, IA Theory of Fole Strain, "American Sociological Roview, Vol. 25, No. 4. Aug. $1960,483-496 ; 4)$ Talcott Parsons, "The Position of Identity in the General Theory of Action," The Self ir Social Interaction, edited by, C. Goudon \& R. Vorgen (New York: John Wiled \& Sons, 1968), 1:11-23.

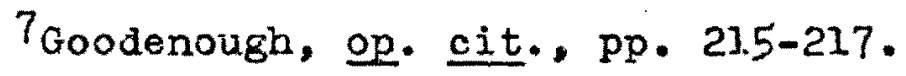




\section{CHAPTER I}

\section{THE WOMEN'S LIBERATION MOVEMENT}

"Women's Iiberation" is a term applied to a current social movement which manifests thelf in a variety of forms and group activities. 1 It is not, as popular misconception sometimes has it, a single body or formal organization, rather, it is a general term used to designate extensive types of independent groups of women who are seemingly united as a whole by a common body of ideas and goals.

This movement is founded upon the increased awareness of some women of the fact that aspects of the woman's position are, according to the ideals and goals for individuals in this society, unequal to those of men; that, in fact, the general social condition of women is unequal to that of men? Women Iabeled "Women's Liberationists" seemingly share this awareness of their social condition. In addition, this awaraness provides the impetus to various current movement activities, and 1t also provided the impotus to the earlier women's ights movement as well.

In terms of numbers, women in today's movement seem to consticute a relatively small minority of the total. population of women : Due to the axorphous structure of the movement, accurate statistics aro difiledit if not impossible to 
obtain. However, if it is possible to judge on the basis of the available literature pertaining to the movement, on the sudden proliferation of college courses dealing with the condition of women, and on the responses to the movement in the mass media, it is widespread and growing rapidly. 3

The specific stated aims of individual Women's Liber. ation organizations within the movement are numerous. They range from demands for equality of educational opportunities with men to equal pay and equal job opportunities for womer. In addition, various groups are seeking free day-care conters and legalized abortions for women all across the country. The aims of some groups concern elimination of the double standard as regards sexual behavior for men and women, while other groups, sometimes labeled extremist or "the enfants terribles of the movement"4 seek total segregation of the sexes and complete social revolution. 5

Variation in the specific aims of individual groups has resulted in a split of goal orientation between reformist and revolutionist approaches, and whether the movement should be reform oriented or revolution oriented remains a nuch disputed and unresolved issue for many groups. Kyriakos M. Kontopoulos says that:

There is, however, some evidence that the radical [e.g., revolutionary7 groups are gaining in importance. On the other hand, one sriould not beliave that there is unity among the many radical groups of Women's Liberation, and this in spite of the fact that there is an apparent coalition and fairiy well oxpressed coactivation vis-a-vis specific 
issues, like abortion.7

Regardess of the general lack of positive unity and specific policy orientation, Women's Liberation groups seok to achieve the general liberation of women in terms of economic, social, and political equality with men. Moreover, the Women's Movement of today has its antecedents in the recent historical past, and this should be examined in order to view the current Women's Movement in its proper perspective, and in order to understand and appreciate current Women's Liberation activities.

\section{SOME HISTORICAL ANTECEDENTS}

Wonen's Liberation groups are not new phenomena in American society, nor are they restricted to the activities of the suffragists familiar to most Americans from a paragraph or two in their elementary history books. 8 viewed in its early development as the "Women's Rights Movement," and currently as the "Women's Liberation Movement," tho whole might be more properly degignatea the "Feminist Movement." The origins of the earliest feminist movement appear to be related to a number of factors which include changes in the form or the family over time which directly affected the lives of women, 9 the esrly industrial revolution which produced social changes in women's lives, 10 the abolitionist movement which drew women into publjc political activity, and the rise in opportuntities for higher education for wo- 
men. ${ }^{11}$ Although it is difficult to establish a positive cause and offect relationship it seems that all of these conditions contributed to the development and growth of the feminist movement.

Tho most significant of the contributing factors to the rise of the first feminist movement appears to be the abolitionist activities of the nineteenth century. Howerer, the groundwork for the rise of feminism agd been laid prior to this and is reflected in the historical writings of the times. Mary Wollstonecraft's work, A Vindication of the Rights of Women, appeared in England in 1792; Abigail Adams was complaining ajout the position of women, in writing, in 1777; and, number of Now Fngland women around the turn of the eighteenth century were writing about the social and legal position of women. 12

The writings of these women, and others like them were ahead of their time, but they holped to lay the foundation for iater feminist activitios. The great humanist philosopher John Stuart Mill later published an essay (in 1869) entitled "The Subfection of Women," which was in- . fluenced by Mary Wollstcnecraft's work, but by the time Nill's essay was putlished the feminist movement had gainod extensively in adherents and strength and had taken on a definite "movement" quality. $\$ 3$

In the late 1620 's and esrly $1830^{\prime} \mathrm{s}$ Northern women of middle and upper class backgrounds, generaliy with some 
higher education, were becoming active in the movement to abolish slavery. Working as abolitionists many of these women were immediately faced with the restrictions placed on their own persons; and, in addition, it became quite difficult to avoid the parallels in the social condition of women and that of slaves. Women at this time were under the immediate legal and economic jurisdiction of men, either thelr father's, their husband's, or some male relative. Women in groups found they had difficulty meeting in puolic, and special difficulty in being heard or listened to in mixed publis meetings. They discovered that being an abolitionist meant dealing first with the authority of white males; it also meant dealing with the issue of "whose rights should be obtained first." Black abolitionist and white women working together often found themselves debating the issues of "Women's Rights versus Black Rights" (Black males) and the moderates among them chose to put aside the question of "women's Rights" until the abolition movement could be achieved and suffrage obtained for Black men.

The Society of Friends played an interesting and significant role in the feminist movement, toc. The first $a b-$ olition societs was formed by the society of Friends (in 1783 in Britein), and the Society of Friends was alone among the major religious institutions to permit women a voice in religious affairs. Women in the Guaker church were allowed to speak at meetings and often ordained as rinisters. More- 
over, the Soclety belleved women should be educated and instructed in "whatsoever things wore civil and useful in creation."14 The opportunity which the Quaker church provided its women members was inestimable and reflected repeatedly in the fact that the majority of women prominent in the abolition movement and active in forming the women's rights movement and later suffrage movement were Quakers, women like Ilizabeth Cady Stanton, Susan B. Anthony, and Lucretia Mott. But there were other women who contributed their efforts and talents to all of these activities as well. In 1840 an ant1-slavery convention was held in London and abolition societies from all over the interested and participating Western World sent delegates. Included among these were three women delegates from the United States, Iucretia Mott, Ann Green Phillips, and Elizabeth Cady Stanton. The first issue the convention raised was the seating of these delegates. The traditions of the time did not readily permit women to engage in public political activity, and moreover, the convention had not invited women, and it was not considered proper for women of the Victorian era to appear in public especially to discuss political issues with men in public meetings. 15

At this point, the World Anti-Slavery Convention came to a stand still while the issue of seating the women as legal, voting delegates was debated. Some felt that the entire convention should be dissolved rather than admit 
women delegates on an equal basis with men. The convention, held to discuss the issue of equal rights for Black people, would permit these women delegates frors Massachusetts and Pennsylvania to attend the convention only if they were seated behind a curtained enclosure and remained silent. 16 The women delegates adjourned to a near-by hotel to discuss the absurdity of the situation and decided that they must hold a convention of their own. In 1848 Blizaboth Cady Stanton and Lucretia Mott called the first women's rights convention which met in Seneca Falls, New York. ${ }^{17}$

To make the situation additionally poignant the women who called the first Women's Rights Convention had to "break and enter" in order to use the hall they had previously arranged for because a group of men locked the doors feeling that such a convention was not "proper" for women. 18

It was because of their active participation in the abolition movement that the women who held the first Women's Rights Convention had learned to organize, to hold public meetings, and to conduct public petition campaigns. Moreover, as active abolitionists they first won the right to. speak publicly and, in addition, they began to develop a philosophy of their basic rightes and their place in society. All of this political experience went into the making of a successful convention at Seneca Falls.19

At this convention, generally regarded as the birth of the movement for women's rights, the women in attendance 
drew up the first public declaration of rights for women. Modeled after the American Declaration of Independence, their declaration was addressed to "Man" and listed a long set of women's grievances. The only resolution the women failed to pass unanimously had to do with women's enfranchisement and although it ultimately passed it did so by a very small margin. Many of the women in attendance had been working long and hard for the abolition of slavery and in their views that issue took precedence over suffrage for women in general. The ideas expressed at the Seneca Falls Convention spread rapidly and there followed more meetings so that by 1850 the effects of this first women's rights convention were felt as far west as Kansas and Wisconsin.20

With the exception of the year 1857 national women's rights conventions were held every year from 1850 to 1860. However, no permanent women's rights organization emergod during this time, only a loosely formed steering committee, referred to as the Central Committee, was active and this was composed of one or more women from any state having any women's rights activity. 21

Although the women at that time ware denied suffrage, the early women's rights movement displayed little interest in obtaining the vote, with perhaps the exception of Elizabeth cady stanton. The most immediate iasues on which the women focused their attention had to do with control of their own property, control over thejr own earnings (at that 
time both were prohibited by law), divorce, guardianship of their children, opportunities for employment and oducation, their lack of legal status (women could not bear witnoss or sue), and the entire concept of female inferiority which was perpetuated by established social and religious traditions. In fact, one of the early protestors of the ideas of women's intellectual inferiority was Mary Wollstonecraft, and the essay on "The Subjection of Women," by Mill dealt extensiveIy with the contradictions in this idea. His argument is an interesting and amusing one, and incldently depicts the subservient role of women:

... that women are considered fit to heve such a cholce $\overline{2}$ s to who governs them7, may be presumed from the fact, that the law aIready gives it to women in the most important of all cases to themselves: for the choice of the man who is to govern a woman to the ond of life, is always supposed to be voluntarily made by herself.

Mill argued for woman suffrage also. 22

Religious tradition strongly affected the status of women and the argument against the Biblical justification for the inferior position of women was dealt with very eariy in the feminist movement by Sarah Moore Grimke, in an. article called "The Equality of the Seres and The Condition of Women" (1838). Miss Grimke was also instrumental in opening the way for women to spoak publicly, and she, along with her sister Angelina, was active in both the abolition movemert and the feminist movement. Sarah is 
frequently cited in today's feminist literature for the following statement:

I ask no favors of my sex...All I ask of our brethren is that they take their feet from off our necks.23

Women who were active in the feminist movement during the nineteenth century came largely from upper and middlocless backgrounds. These were the women who could have household help, who were able to obtain a higher education, whose labor was not drawn into factory work, and who could afford to participate in social reform movements. They became active and gained political experience not only in the abolition movement, but prison reform, mental cere reforms, schooling for women, and education for Black poople as well; and they were systematically moving into occupations formerly held exclusively by men. In 1848 Maria Mitchell, the astronomer and a feminist, was the first woman to be elected to both the American Academy of Arts and Sciences and the American Association for the Advancement of Science, Sho was incidently a Quaker. In 1849 Elizabeth Blackwoll bocame the first American woman to be certified as a medic al doctor. Her personal struggle to gain admission to medical school and to be permitted to attend all her classes is an interesting example of the barriers women faced in obtaining entry to men's professions. The first woman to be admitted to the bar was Belva Lockwood. This event did not 
take place until 1879. Although she could, in theory, practice law, she did not have the right to vote, a right women were not to obtain until 1920, after a very long period of struggle.24

In Century of Struggle, Eleanor Flexner explains the situation women faced this way:

Bocause it took so long for women to be admitted on a basis of equality to existing professional organizations, they were compelled to establish their own, in medicine, law, and other fields. These orgamizations continue to exist today as evidence thet professional women still encounter prejudice and special difficulties in carryling on the work of their choice. 25

As the women of the nineteenth century woriked to be permitted a place in public life they founded women's colleges in increasing numbers making it possible for larger numbers of woren to get educations and become eligible to participate in public activities on professional levels. However, such educational opportunities remained largely the privilege of the well-to-do. Nevertheless, such opportunities holped reduce social resistence to having women participate ir public roles and also produced the women who were to make the women's suffrage movement successful. .

In the history of the struggle for women's rights the suffrage movement remains the longest and most hard-won of all the issues nineteenth century women struggled to obtain. The struggle for enfranchisement began with Elizabeth Cady Stanton at the Seneca Falls Convention in 1848 . It grew more important as a public issue arter the Civil War and the 
passing of the fifteenth amendment granting suffrage to Black males. The majority of the women who deroted their lives to the cause of woman's suffrage died before it bocame a reality, Mrs. Stanton, Susan Anthony, Lucy Stone, Anna Howard Shaw, among some of the more prominent, but they had worked with the suffrage movement while generations of women came and went in their organizations. The following statement from Flexnor's history of the woman's rights movement explains in part why obtaining the vote was so difficult.

It cannot be repeated too often that for women working a ten or twelve hour day, whose earnings were almost half those of men, whose lives were often bounded by the sweatshop, and whose relation to their employer lacked any safe-guards to porsonal dignity or job tenure, "equal rights" was a question of more than education or getting the vote. For them equality also meant bettor pay for their labor, security from fire and machine hazards or the unwanted attentions of a foreman... Until more of them could work for these goals through a trade union, other issues were remote and unreal, a fact partially attested to by the relatively small degreo of participation by such women in the suffrage movement. 26

Opposition on the part of the rallroad companies, liquor distributors, and manufacturing corporations also. holped to delay the passing of the ninetoenth amendment which gave women the rote. Then too, resistence on the part of women themselves was a factor. Women felt then, as some do now, that status and security in being a woman resided in having husbands "to look after their interests, and they noeded no new laws to protect their rights."27 
There are some additional situations of note in the nineteenth century feminist movement which repeat themselves in the noo-feminist morement in the 1960's, and these are the opposition on the part of the press to women's activities, and the question of costume.

In general during the early years of women's rights organization, $1840^{\prime} \mathrm{s}$ to $1860^{\prime} \mathrm{s}$, the press did very little to further the women's cause. Their reporting was elther ab. sent or unfavorable, they were intent upon ridiculing women's efforts in their own behalf and consequently women had to rely on either the abolitionist papers to report their meetings or publish fournals of their own. The masthead on Susan Anthong's early journal read "Men, their rights and nothing more; Nomen, their rights and nothing less." This publication, entitled The Revolution, came out on January 8 , 1868, and was the first woman's newspaper, to be followed by numerous others. 28

As to the is sue of costume, in the latter half of the nineteenth century feminists staged a clothing style revolt rosulting in the "Bloomer costume" and suffragists were. known as "BJoomer ginls." However, the immediate consequence of this has public ridicule.

If the women wore physically noro comfortablo, they suffered untold mental tortures. The $\mathrm{g}$ wore tho butt of unceasing ridicule, from newspaper editors to corner logiers and sinall boys.

Eventualiy the costume was discarded with the justification that the women could then better utilize their energy in 
more productive purguits.

This first feminist movement came to an end with the winning of the vote. Most authors of women's history generally concluded that the women had worked so long and so hard in the cause of women's suffrage that their energy was spent and the organizations the had created for this purpose were no longer needed and eventually disappeared. 31 The exrly feminists did more, however, than win the vote, they won the right of women to inherit and hold legal title to property, to legal possession of their own earnings, to obtain divorce, to have legal guardianship over their children, to testify in courts of law, to sue, to sign contracts, to becomo doctors, lawyors, scientists, or whatever, and to a place in public life.

Since the early feminist movement was so successful in winning rights for women one could ask the question of today's movement, "what do these women want?" To answer this question it is necessary to examine the current Women's Liboration Wovement and the ovents which produced this neofominist resurgence. 
THE RISE OF NEO-FEMINISM

The 1920's onded with the stock market crash of 1929 , then came the depression years of the $1930^{\prime} \mathrm{s}$, and World War II. World War II dramatically affected the lives of Amer1can woman but it did not directly give rige to any noofeminist movements. Women were recruited into the labor force in large numbers to meet war production needs while men were going overseas. The ability of these women to qualify for jobs was nover an issue. They became truck drivers, welders, technicians, and in general met the domands of industrial production wherever they were employed. Moreover, no one claimed they were "unfeminine" nor that they were neglecting their children and their homes by taking such jobs.

In 1944 and 1945 women were slowly let out of their war production jobs and returned to the private sector of American society, while men returning from the service went to college in increasing numbers on the G.I. Bill and replaced women in available jobs in business and industry. The disappearance of large numbers of women from the labor force is repcrted by the Bureau of Labor and news media as a "withdrawing from" or "dropping out of" the labor force. It occurred, interestingly enough, at a time when it was convenient for American business and industry. 31 Anajysis of statistics and various mageino and nows 
publications for the fifteen years following the end of World War II shows that women were being encouraged to stay home and be housewives and mothers. The "baby boom" reflects the fact that this was exactly what the majority of these women were doing. 32

It would be contrary to fact, however, to say that a conscious effort was being made at this time to keep women in the home, more likely women's magazine editors felt it necessary to write about and reflect what the majority of women were actually doing. The scarclty of the depression years was being compensated for in the affluence following World War II. Moreover, the cultural ideal for women has been that they be wives and mothers as their major occupation; and, when circumstances permit, this is what the majority of women do.

Then in the 1950 's women again began questioning the "role of woman," the traditional concept that "woman's place was in the home." Simone De Beauvoir's classic work the Second Sex, was printed in this country in 1953, and The Feminine Mystique, by Betty Friedan, came out in 1963 and. was immediately a best seller. These were the first of the neo-feminist publications to stir the imaginations of women in large numbers. Both books dealt with the concept of the inferior status of women and its causes. 33

In spite of these two early major puclications, the noo-feminist movement was still slow to cetch on. Women 
read these books in the privacy of their homes, but they did not rush out to form any organizations. The dovelopment of orfanizations came again in the wake of civil rights activitios.

During the $1950^{\prime}$ 's more women than ever before were attending colleges and universities and they were becoming more publically involved. At the same time large numbers of Black veterans were returning to school on the G.I. Bill following the Korean war, and the contradiction the Blacks felt between American ideals and racial discrimination gave renowed impetus to the civil rights movement, a movement participated in by white malo and female students all over the country.

Participation in civil rights activities again provided women with the opportunity to develop some political skills and it gave them the political experience to understand the conditions of their own lives. Women went South in large numbers to help register Black people at the polls. Working with young male students in the same kinds of activity the women found themselves assigned to tasks normally. assigned to them, making coffee, fetching food, cleaning up, typing, and routine of rice work. They were systematically excluded from activities which would permit them to make decisions or develop leadership silils. These areas of activity the men reserved for themselves. In addition, out of civil rights activities engaged in by students came the so- 
called radical student organizations, the S.D.S., S.R.I.C.K., and the Berkeley Free Speech Movement, student strikes, the Pesce rovement with its anti-war demonstrations, and the "drop-out" counter-culture movement with its so-called "hippie" communes.

During this time women began to translate their political experience in these activities into political theory and to develop new women's rights groups. Initially, the frustration experienced by women in dealing with men in various civil rights organizations was simply that, individually felt frustration. However, the frustration led to the formation of "rap" groups in which women got together, without the men, to discuss their individual problems and the experiences they were having. These rap groups became the heart of the neo-feminist revival in the early 1960's. By mid-1960 rap groups were forming throughout the country and their purpose was clearly "Women's Liberation."

The basic aim of the rap groups become "consciousnessraising"; that is, to develop in the participating women an awareness of their situation as women, a "consciousness" of the social condition of being female with its resultant discrimination. Moreover, the iap groups aimed, not at group therapy, but at the formulation of political theory, the idea that women should transiate their personal experiences into political theory and action. 34

At this same time women began to publish. There were 
widespread activities and groups formed during this time. organizations like the National Organization for Women (NOW), Redstockings, the Radical Feminists, SCUM (Society for Cutting Up Men), and WITCH (Women's International Terrorist Conspiracy From Hell), came into being. When feminist groups picketed the Miss America contest in Atlantic City in 1968 the Women's Liberation Movement drew national attention. 35

Thus, during the $1960 \mathrm{~s}$ a new impetus in the direction of emancipation and self-actualization of women manifested itself. This impetus was expressed in a number of ways: first, in a radical search for iajentity; second, in the literary articulation by numerous women writers; and, finalis, in the creation of noo-feminist groups. 36

The new burst of feminist activity differs from the earlier feminist movement in the fact that its focus appears to be on "personal liberation" as opposed to "group liberation" (e.g., obtaining legal status for women as a whole). Women who are drawn to today's moverent appear to be seaking individual liboration, and they express the fact that they feel thwarted in a varioty of ways, largely, but not entirely through their roles as women. The women in the new movement appear to be interested not so much in changing the lives of others as they are in changing their own lives first. One witer sums it up this way:

The movement at the present time is in the process 
of developing an understanding of the condition of women and increasing the awareness of the problems of women both in its adherents and in the society as a whole. 37

The rap groups, designed as they are to permit women to share their experiences, are attempting to implement change in the traditional status of women on a personal level by developing the individual woman's awareness of the implications of her existing status. Barbara Bovee Polk states that:

The changes which women attempt to lmplement usually begin with altering attitudes and interactions in relationships with husbands, boyfriends, employer, co-workers, and femsle frjends, with the goal of seeing oneself, and being seen, as an equal in interpersonal relationsipips. This change is perhaps the most difficult and the most fundamental for the Women's Iiberation Vovement. For to change interactions, a woman rust begin to change her entire concept of herself and begin to present a self-image which dexiates from the accepted norms of the society. 38

Thus, the ideological grounds of the neo-feminist movement are markedly different from those of the nineteenth century feminist movement.

The issue of a "radical" search for identity is an interesting one, the one which differentiates the feminist movement of today from its historical counterpart. Moreover, it is an issue which appears to be relatively little understood, even by the various groups with-in the movement, Yot it is the focal point of the rep groups which provide the founation for the whole movement. Further clarifica- 
tion of this neo-feminist ideology might be found in the following statement:

The movement, in terms of radicalization, begins with the reformists (NOW) and steps, first, toward the groups that advocate a total restructuring of the society and its values for the sake of both women's and men's liberation. Those groups do not claim that men are oppressors (at least not consciously, or at least not all men) but belleve that men, as much as women, are victims of the socialization practices. Another step forward is to be found in the radical feminist groups that stigmatize the oppression and name men as oppressors... The final stop brings us to the position taken by some... groups that preach separetion from men, and possible, rejection of marriage and the family, and in a few cases, total sexual separation. 39

An additional aspect of modern feminist organizations

is the focus on memberghip equality with the concomitant de-emphasis on personal leadership within the movement. This aspect aims to eliminate what women in the movement consider "oppressive male-dominated leadership forms."

... it is an attempt to build an egaljtarian movement which serves as a model for an egalitarian society.

Women's Liberation is perhaps the first social moveme:at in recent times to take the idea of equality seriously... The significant social development in Women's Liberation is that wonen can $80 \theta$ that little will have changed in their. lives if they are willing to substitute the domination of organizational leaders for the domination of

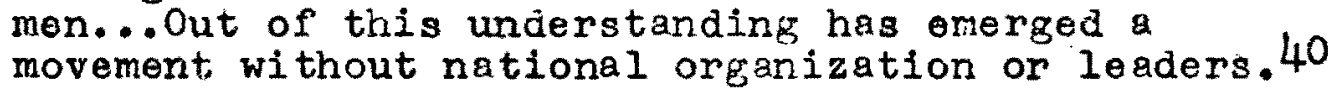

Thus, in general, women in today's movement are attempting to avold male leadership and hierarchy patterns.

Aside from being qualitatively different in its ideological perspective the feminist movement of today sheres a number of characteristics with its nineteenth century 
counterpart.

First, there is the similarity in national organizational structure. Both the past and present fominist movoments represent an uncrystalized organization. The National Orgenization for Women (NOW) is the largest of today's feminist bodies, in terms of numerical membership within the movement as a whole. NOW alms at a number of goals and employs various types of activities to attain them; it holds national conventions, participates in demonstrations, pursues court cases on discrimination against women, hires lobbyists, publishes pamphlets dealing with the economic and logal status of women; and, in addition, it is concerned with ending employment discrimination against women, forming daycare centers for children, reforming abortion laws; and, in general, taking action to equalize the social condition of women (many of these goals are shared by other Women's Liberation groups as well). This organization is comparable to the "Contral Committee" of the nineteenth century in its structural form.

Second, like the first feminist movement, today's. movement is composed largely of middle end upper-middle class women, who are well-educated, professional or semiprofessional women. And further, most all of today's fentinists have had some college education.

Third, like their early counterparts, today's feminists ale not given much positive response from the general 
public or the mass media. Press reportings are often inaccurate and more often slanted in tho direction of deliberate ridicule. As in the past, the public statements of men claim "it is the gentlemen who are the sufferers." 41 Moreover, inaccurate reporting in the press produces tho same general confusion and hostility on the part of the general public, and many people are either totally ignorant of, or completely confused about, the Women's Liberation Movement of today; and very few have any knowiodge of the first feminist movement aside from some scanty information regarding the suffragists. 42

Finally, there is the similar situation as to costumo. Today'a fominists, many of them at least, are attompting to implement clothing style changes with the public response of "they look like they could go bear-hunting with a switch," or some similar statement to indicate disapproval of what they consider "unfeminine" appearance. 43

I have found it interesting to compare the American public's response to the fominist movements, both past and present. This response remains rooted in seemingly conservative tradjtions. Over onehundrod yoars have elapsed sinco the start of the first feninist movement and I see considorable segments of today's public responding with the same limited undorstanding, riduculo, and hostility that was displayed in the nineteenth century to the game phenomenon. In surmary, today's Women's Liberation Movement is 
omploying three general mothods to achieve social equality for women. These three methods are: first, attempting to achieve personal liberation through "consciousness raising;" second, attempting to gain social liberation through political action; and third, attempting to acquire organization81 liberation through actions for organizational equality, that is, de-emphasizing personal leadership and focusing on membership equality.

It is however, with the issue of the ideological differentiation between the feminist movements that this study focuses on. Whereas the early feminist movemont concerned itself with obtaining specific legal, social, and economic rights for women, today's movement is differentiated by its concern with the over-all cultural position of women and the psychological impact of the socialization of women. Today's feminists are concerned about the traditional role of women in the family and the psychology of feminInity and how these affect the developrent of women and how they tend to keep women in inferior positions, and in their concern about the effects of women's soclalization they are attempting to provide answers and alternatives. 44 They stress primarily the importance of a complete new identity for women. This issue, the question of identity change, provides the focal point of today's movement, and in a somewhat differont sense, the focal point of this research. The question the present research asks is whether partici- 
pation in the movement produces identity change in members and if so does it follow anthropological models of identity change process. This will be examined in detail in the rollowing chapters. 
FOOTNOTES

CHAPTER I

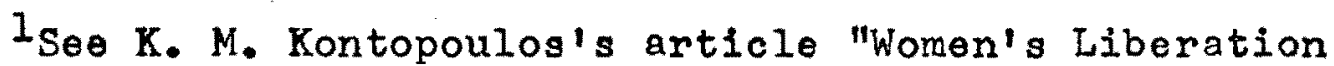
as a Social Movement" in Toward a Sociology of Women, edited by Constantina Safilios-Rothschild, (Lexington, Yass: Xerox College Publishing, 1972), 354-361. Historically, women's rights movements were designated by a variety of terms; Women's Liberation is the modern title.

2Indeed, some observers say that: "The case of women is by $f \& r$ the most iniquitous case of exploitation and alienation in history." Ibid., p. 354.

3 Publications of materials regarding the movement and related to the status of women in general are proliferating so rapidly that an individual compllation of all of these materials would bo an extensive research task in itself. At one point in my research on the literature available I found myself collecting bibliographies of bibliographies. The one appended to this paper represents only a small sample of the current materials available on the movement. The bibliography by Marija Hughes, The Sexual Barrier: legal and economic aspects of employment, (San Francisco: Hastings College of Law, 1970), contains over 500 sources regarding women and discrimination (some of which are reduplicated in my own bibliography), and this is only one example of resources dealing with the subject. Moreover, almost any popular magazine or periodical one examines these days is sure to include an article about or in reference to some aspect of the Women's Liberation Movement. And, as of January 1972, there were 3.7 women's studies centers and over 600 courses on women's studies being offered in colleges and universities across the country.

4Kontopoulos, op. c1t., p. 357.

$5 \mathrm{~A}$ perusal of even one popular anthology of writings from the Women's Liberation Kovement will provide the reader with a statement of these stated aims, and more. For further research into the ains of the various groups in the movement, read the book edited by Rovin Morgan, Sisterhood is Powerful, (New York: Vintage Books, 1970). Also the article by Kontopoulos, op. cit., pp. 354-361. 
6Kontopoulos, op. cit., p. 357.

7 Ibid. This is not to say, however, that the movement is not affective. Regardless of one's particular point-ofview (e.g., whether one is reform or revolution oriented) the movement is definitely baving an impact on the culture.

8 The proper term is "suffragists" not "suffragettes" as is sometimes used. The term "surfragettes" was a derogatory label at the time of the Woman's Suffrage Movement. See Aileen S. Kraditor, Up From the Pedestal, (Chicago: Quadrangle Books, 1968), 5 .

9There were a number of other historical conditions which played a part also, such as witcheraft trials and religious sect developments, but there is not space here to explore these relationships specifically, and since they are not central to this thesis they are omitted. For discussions about the changing family form seo William L. o'Neill's, The Woman Movement, (Chicago: Quadrangle Books,

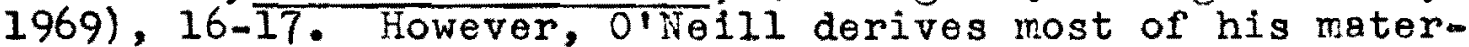
ial about the changing form of the family from a work by Philippe Aries entitled, Centuries of Childhood: A Social History of Fanily Life, (New York: 1962).

10For a discussion of the impact of the industrial revolution on the lives of women see O'Neill, op. cit., and Nona Glazer-Malbin and Helen Waehrers' introduction to Woman in a Man-Made World, (Chicago: Rand MeNally, 1972), Historical evidence shows that general changes in the family form are related to the industrial revolution and, interestingly occurred over the same general time period as the witch hunts and witeheraft trials, the duration of which resulted in the deaths of anywhere from 200,000 (considered too conservative) to 8,000,000 women (considered too large). The fifteenth, sixteenth, snd seventeenth centuries saw the greatest persecutions, and the right of local magistrates to confiscate the property of accused women and their families seems to have been a contributing factor in their continuance over such a long period of time. In addition, they were condonsd by the Catholic Church.

${ }^{11}$ See Eleanor Flexner's, Century of Struggie, (Now York: A theneum, 1959), 9-12, for a fuller account.

12See Flexner, op. cit., and Kraditor, op. cit.

13 Ibid.

14This comment is usually attributed to George Fox the founder of the society. See the history of the society 
of Friends in Encyclopedia Britannica, 1962 edition, Vo1.9, pp. 846-850, for further information.

15Flexnor, op. cit., p. 71. This situation is reminiscent of the present Portland City Club controvergy over a similar issue. Some onehundred and thirtytwo years later it seems men still cannot handle the question of seating women equally in public.

16Floxnor, op. cit.

17 Ibid., pp. 71-77.

18 Ibid.

19Ibid. Flexnor's history of women's struggle for equal rights covers these events in some detall and includes an excellent bibliography.

20 Ibid.

21 Ibid., pp. $81-82$.

22From "The Subjection of Women," by John Stuart Mill, reprinted in Elsie Adams and Mary Louise Briscoe's work, Up Against the Wall, Mother..., (Beverly Hills, Calif: Glencoe Press, 1971), 174-188.

23 Sarah Moore Grimke, "Letters on the Equality of the Sexes and the Condition of Woman," reprinted in Voices From Women's Iiberation, (New York: New American Library, 1970), 38-39, edited by Leslie B. Tanner.

24Flexnor, op. cit., pp.113-130.

25 Ibid. , p. 122.

${ }^{26}$ Ibid., p. 247.

27 Ibià., p. 86.

28 Ibid., p. 150. Many of the early writings on historical feminism have long been out of print and some very difficult to locate. In 1881 a six-volume work, The History of Woman. Suffrage, was published under the general direction of Susan Anthony, who was assisted in the production by Mrs. Stanton, Mathilda Joslyn Gage, and Ida Husted. For a long time the vork remained out of print until current activities in the Women's Movement prodded publishers to reprint the work. Leslie B. Tamer, op. cit., p. 15, noted that she accidently ran across a small volume written by Sarah Moore 
Grimke, op. cit., reduced to only a microfilm copy in the New York Public Library. She points out the difriculty in obtaining these early materials.

$$
\begin{aligned}
& 29 \text { Flexnor, op. cit., p. } 84 . \\
& 30 \text { Ibid., pp. 306-324. }
\end{aligned}
$$

31Betty MacMorran Gray discusses this situation in light of some findings from the Wonen's Bureau in "Sex Bias and Cyclical Unemployment," in Glazer-Malbin and Waerer, op. cit., pp. 235-237。

32 There are a number of studies of the postwar condition effects on the feminist movement and the status of women, the most prominent of these, in terms of feminist writers is Betty Friedan's, The Feminine Mystique, (New York: Dell Fuolishing Co. 1963 ). Betty Poszak addresses herself to the issue in an article entitled "The Human Continuum" in Nasculine/Feminine, (New York: Harper \& Row, 1969), 297-306, edited by Foszak and Roszak. Specific research reports on what "women were being encouraged to do" are to be found in Toward a Sociology of Women, edited by Safilios-Fothschild, op. cit., especially the articies by Margaret B. Lefkowitz," "The Women's Magazine Shori-story Heroine in 1957 and $1967, "$ pp. 37-40, and Lovelle Ray's "The American Woman in liss Media: How Much Emancipation and What Does it Mean?" pp. 41-62. It is, however, the contention of Alice Rossi, "Equality Between the Sexes: An Immodest Proposal," in The Woman in America, (Boston: Beacon Press, 1964), 98-143, that the academic disciplines, in parm ticuler the conservatism of psychology and sociology in the postwar period, undermined feminism and contributed to the trend in promoting women in their sex-role stereotype of housewife and mother:

It is the traditional image of woman / that social scientists theorized about7 which is popularized; the woman who finds complete self-fulfiliment in her exclusive devotion to marriage and parenthood. . Women over thirty years ago might have chosen a career over a marriage, or restricted their family size to facilitete the combination of family and work roles, have been persuaded to believe that such choices reflect their inadequacy as women. (Rossi, op. cit., p. 104.)

33 There were studies being conducted and articles being published by social scientists as well as populer writers, but these have onl. begun to be widely circulated. Writers like Alice Rossi, Karen Horney, Helen Mayer Hacker, Marlene Dixon, Caroline Bird, Esther Peterson, Eana Rostow, 
Joan Erikson, Mirra Komarovsky, to name a few, were also dealing with the status of women and the causes of discrimInation against them. of these writers, only Caroline Bird is very well known among today's public feminist readers.

35 See Kontopoulos's analysis, op. cit.

36 Ibid., p. 356.

37 PoIk, op. cit., p. 329.

38 Ibid., p. 324.

39 Kontopoulos, op. cit., p. 357. This ideological diversification of the various groups with the movement is seen by some as one of the major deficiencies of the Women's Liberation Movement as an affective social movement; however, it depends upon how one defines "affective".

$40_{\text {Polk, }}$ op. cit., p. 329.

4lsee Flexnor, op. cit., p. 88.

42 personal research findings from some twohundred student responses indicate that general public knowledge of the Wornen's Liberation Movement is quite superficial, and two years of research study of press reportings indicate the same is true of reporters. In general, male reporters, reporting for predominantely men's publications reflect quite biased and hostile attitudes towards the movement. For example, see Jim Hampton's article, "The Compleat Revolution: restructure everything, new feminists demand," in the March 9, 1970 issue of The National Observer, page 1.

43 This was a comment made to me by a T.V. newsman of KATU-news, at an aborted news conference with a group of Women's Isiberationists in spring of 1.971. Recently a student made the identical comment in a joumal report in a class I was teaching in Introduction to Women's Studies. Public pronouncements and prejudices are remarkably similar over. time as well as from group to group.

Wh discussion of the ideological difforentiation between the early and modern feminist movements is to be found in Juilet Mitchell's book Woman's Estate, (New York: Pantheon Books, 1971). Also, a detailed analysis of the effects of the psychology of fenininity are covered by Susen Sontag in "The Double Standard of Aging," Saturday Review, (Sept. 23, 1972), pp. 29-38. 
CHA PTER II

\section{THEORETICAL ASSUMPTIONS}

Ward Goodenough devoted a section of his book, Cooperation in Change, to the factors involved in identity change. Essentially he dealt with the processes of identity change as they relate to community development, and how anthropologiats acting as agents of change could utilize these processes in directing community development "because community development is itself aimed at accomplishIng change in some features of a people's identity."I

Goodenough's discussion of Identity change presents an excellent model with which to examine the effects of participation on women in the Women's Liberation Movement: and i.t provides the theoretical basis for this thesis. The following discussion is derived from the description of identity change process in Ward Goodenough's book. Since I am, however, concerned here with the psychological process of idontity change which occurs in individuals, I will discuss Goodenough's model primarily in those terms as oppoed to the language of applied anthropology to wich ho directs his theoretical application of identity change process.? 
IDENTITY CHANGE

Identity changes are part of every individual's life history. Everyone's life conaists of a series of changes in both their public and private images of themselves. These are produced by the succession of events in our lives as we mature, adopt new roles and assume different kinds of responsibilitios. Identity changes can and often are purposely elicited by others as well.

Since some social categories allow for rights and privileges that make them more attractive than others, people continually seek to change their own as well as their fellows' social identities in directions they deem desjable. The same is true of personal idertity. 3

The process of identity change for the individual is a consequence of specific kinds of realizations which are fostered by a series of definable stages. These will be examined in detail in the subsequent discussion.

The Essentials of Identity Change

The necessary conditions for identity charge consist of: first, a desire on the part of the individual for identity change; second, a commitment to making the change; and third, an understanding of what needs to be changed. These conditions often include making chanees in roles and styles of porformance, as woll as adjusting physicolly and omotionally to these changes in stylo.

In addition to these essential conditions, the atti- 
tudes and bohavior of others are essential for effecting permanent identity change in the individual, because the new identity needs to be recognized and accepted by others In order to facilitate lasting change and to further enable the individual to conceive of him or her self as possessing a new identity. Such acceptance also signals the beginnings of true socio-cultural change.

\section{THE DESIRE FOR IDENTITY CHANGE}

The desire for ldentity change can be achieved in a number of ways: one, by having the person become acquainted with the public image of themself in such a way that if by seeing themselves as others do they will want to change. Or, two, in the case of directed change, an effort can be made by another to make the individual's present behavior no longer gratifying. A third moans of achieving a desire for identity change may occur as a result of the indulgence by a second party of some previously frustrated want as an Inducement to change. Whatever method is employed it must provide the necessary inducement to motivate the individugl to change. 4

Moreover, if permanent identity change is to take place outward conformity to the new behavior is not onough. To be fuliy effective the porson must change their private viow of themself and further, want to change this view. As with religious conversion, the real change which takes place 
must be in how the person soes themself and not simpiy how they see the new bellef system they are adopting. The identity change then comes about when the person feels compelled to repudiate the old identity in favor of a new one more in keeping with their ogo-ideals. 5

Identity change should, ideally, improve "the feeling people have about themsolves, so that their capacity for self-improvenent and furtber self-development is increased. 6 Thus, in order for this ideal to bo realized the identity change which occurs needs to be sustained by the individual. This can result through reappraisal of the self-image on the part of the Individual as woll as by learning some new criteria for self-reappraisal.

1. Resporaisal of self

Reappraisal of one's self is a major factor in achiovIng a desire for cherge. Reappraisal of one's viow of oneseif can be both ovaluative and cognitive.

Evaluative Regppraisal. Evaluativo reappraisal involvos reviging one's estimation of oneself while continuing to see the self as essentially the same kind of person they havo always boen.

Compitive Reeppraisal. Cognitive reappraisal involves soeling onssolf 8 a different kind of person with personal characteristics significantly different from the ones the person formerly thought they had. This also involves as- 
pects of ovaluation.

While changes in self-esteem and self-image are linked, they ropresent distinctly different dimensions in terms of which people reappraise thomselves. 7

Either kind of reappraisal has to come about with new experiences. These experiences may or may not be wanted; that is, experiences can result from circumstances beyond the individual's control or they may be deliberately sought, at the same time the experiences can be completely without procedence.

A change in the categories by which we perceive things, in our own criteria for evaluating what we perceive, or in our habits of using these categories and critoria will necessarily lead to now experiencos of our own selves, even when objectigely there has been no change in our circumstances. 8

Effort is another factor involved in 1dentity change in that some kinds of perspective change require little or no effort, while others require a great deal, but if the effort at change in ways of perceiving various categories of an individual's behavior $1 \mathrm{~s}$ made, radical reappraisals of identity can result.

In adition,

Since people tend...to perceive themselves as well as others in terms of those categories about which they are especially concerned emotionaily, there is usually considerable room for them to revise their porcoptions in teims of other categories that are also applicable. 9

Poople quite often have difficulty making porspective changes simply because they do have emotional invostment in 
looking at themselves. It is possible, however, to stimulate shifts in perception by getting people to consider a new view of themselves, to examine their position in light of other considerations. Confrontation is one method of stimulating such a shift.

Confrontations can be the result of accidental experiences on the part of the individual or they $c$ an be introduced deliberately by others. Confrontation with the selfimage, however, often leads to resistance because of a sense of being pushed or threatened, but continual confrontation may also produce new inalghts into behavion and lead the individual to change their wants and felt needs accordingly, thus producing new behaviors and concommitantly a new selfImage. 10

Confrontation can often be elfcited simply' by being confronted with a proposal for change. For example, in the case of applied change the inftial exemination of community conditions by the developing agent making the proposals can have the effect of confronting people with themselves. Education is also a method of confrontation and works to induce a foeling for a need for change. A variety of confrontation mothods which are edueational in nature are involved in identity change, chief among these is psychological counseling. 17

Under conditions of psychological counseling we are confronted with ourselves by a colinselor who shares the 
samo general criteria that wo do for percelving and evaluating identity features. He and we may, however, be in the habit of using them differently. And again, both the person and the counselor can share the same understanding about whatever agpect of reality they are exploring, but the counselor may find it necessary to get the individual to explore this understanding from different perspectives. Such educational confrontations can lead to reappraisal of one's golf. 22

2. Learning Naw Criteria for Self-Reappraisal

Idontity change is further facilitated when the individuel learns new criteria for self-reappraisal. One method of learning new criteria involves defense in the face of disconcerting confrontation. When the person is confused by the events they are confronted with they are forced to make an effort to learn new discriminations in order to escape the confusion. 13

Second, the person learne things from others by being subjected to experiences they have not had before and by being in at tuations that are sharply defined with reference to the new porceptions to be learred. Thus, the person can structure their experiences in such a way as to learn now criteria for self-reappraisal. What is nocessary, as followup, is to have the possibility of applying the new perceptual frame to other contexts as well to make the neappraisal lastingly offective. 14 
A third method by which the person is provided with the necessary kinds of new experience needed to lesm a particular way of perceiving something is through demonstration. This is part of the educating practice, and such practices can be accidental or deliberate depending upon the circumstances of the individual; either can, however, be effective.

Once acquirod... people must continus to have experiences to which their new perceptual and ovaluative systems are applicabale... If daily experience is meaningful in terms of one system alone, then the other is superfluous and will become inoperative. If...a person is to operate exciusively in terms of a new system of categories and values, then he must not be put in situations where it is of no use to him. 15

Thus, a desire for change is effected by seeing one's self in new ways through reappraisal of the self, either evaluative and/or cognitive reappraisal; through having new experionces and making effort towaris reappraisal, and through learning new criteria for self-appraisal as a consequence of the defenge of self, and/or by being subjected to structured experiences, through educating demonstrations, and by having the opportunity to apply the now knowledge of one's self. 


\section{COMMITMENT TO CHANGE}

In order for identity change to occur it is necessary

for there to be a commitment to such a change.

The new roles that a new social identity requires us to play are likely to call for important modifications of our previous personal style. Ways in which we have habitually displaced and sublimated emotional problems may no longer be suitable, adding to the uncertainty about our ability to bring off the change successfully. Changes in social identity are a source of anxiety for an. other reason. It tokes time to learn new roles and to become habituated to a new conception of self. The period of transition is likely to be characterized by confusion as to just what one's Identity is. 10

Individuals prepare themselves for changes in a number of ways, one is by anticipating their new social status, and another is by adopting roles that are appropriate for the new identity. Sometimes when identity change is impending the person comits themself to various obligations that make retreat from a change difficult.

...stimulating commitment to change can be highly effective with changes in social identity, especlally those changes that are part of the normal Iifo process. They help to overcome reluctsnce generated by anxiety and shame about changes.17

Fart of the process of comitnent to identity change often involves the person giving up or destroying old symbols associated with their former identity. Sometimes, too, dramatic behavioral changes are part of the commitment.

A person may exhibit a sudden new rudeness or a radical change in dress and mannerisms and thus force others to regard and treat him dif- 
ferently from the way they did before. By thus ridding himself of the kinds of treatment he received in the past, he destroys something of his old identity. The effect may be to lower his estimation in his fellows' eyes, but it will have changed it from what it was, at least, breaking his identity out of its oid nold. Whatever his new behaviors are, to be effective the $y$ must be dramatic enough in their impact to make it impossible for others to go on viewing him as they did before. 18

Performing actions that are considered antisocial are one effective means of producing identity change and consequently a tempting method of commiting oneself to the process, simply because antisocial actions are dramatic and direct, and because regardiess of the consequences the individual cannot be the same person as before. Extreme antisocial actions occur when the person focuses on the problem of change mainly as one of giving up their former ideritity altogether and has only a minor concern for what the new identity will be:

...because identity change necessarizy involves the replacement of former identity features by new ones, it almost inevitably appears to require the eradication of some part of one's former self. The act of eradication, therefore, is the one by which we commonly take the plunge. And the more anxiety people feel about change, the more convulsive and violent the act of comritment is likely to be. 19

Social revolutions are a typical example of this response to identity change process.

To summarize, the second nocessary condition of identity change, commitment to change, is achieved when the person porforms zome action that enables them to enticipate 
their new status, perform in the new role, or engages then in some physical and/or psychological commitment to the new identity.

III. UNDERSTANDING WHAT NEEDS TO BE CHANGED

The third necessary condition of the identity change process involves an understanding of what needs to be changed.

No matter how dissatisfied a person may be with his present identity, in order to change it he must have some credible explanation of what is wrong and what needs to be done to correct it. 20

All human groups exert pressure on their individual members to achieve identity changes that are considored valuable within their respective societies. Moreover, different social systems provide a number of alternative identities for their members and individuals discontent with their existing identity have a range of identities from which to select a new one (the number of altemative identities available varying from one group to another). In addition, any given society usually provides models to illustrate concretely a range of identity objectives, thus the individual can compare themself to some concrete model in order to determine the new idenity form they wish to achieve. 21

- Sometimes, however, the individual is confronted with various social restrictions on identity change achievement therefore, it is necessary to exemine some of these problems 
along with some possible solutions.

1. Problems in Achievement

The adoption of a new identity must be considered in light of various problems which may exist within any social system to block changes.

First, the identity change the individual might wish to make may involve difficult if not impossible social alternatives in their society because the changes contrast too sharply with what the society considers appropriato. For example, poople who wish to change their owtward sexual appearance by dressing like members of the opposite sex often find themselves either severly ostracized, jalled or limited to displaying such behavior in private.

Second, changing social or cultural circumstances can block the individual from achieving change. This can be exemplified in the problems presented to many American Indians when they found themselves unable to pursue their usual cultural activities and at the same time refused entry into the dominant society. Alcoholism. resorting to violence, and religious cult activities rollowed.

Finally, when an individual's new experiencos lead them to re-evaluate the worth of the traditional models as identity change alternatives, they find, or may find, that these models have lost their appeal as alternatives. 22 There are, however, a number of solutions to these 
problems.

2. Solutions to Problems in Achievernent

When tho individual is forced to find alternatives within the existing social structure, there exist a number of posstble means whereby the person can achieve self-fulfillmert. First, the individual can:
...try to persuade his fellows to change their evaluation of his present identity and accord it the same privileges and esteem that more de- sirable identities in the social order enjoy... This approach seoks to accomplish a change in the scale of values and in the allocation of rights and duties to existing social categories, but does not seek to directly change the cate- gories as such. 23

A second means is to seek mermership in a new community where a different system of social categories exists. This is the basic attitude of segregationist movements. It is sometimes possible to find a new community within the larger society in which the identity changes the individual wished to make will be possible. Homosexual enclaves in large metropolitan aroas are a typical example.

A third means to achieving identity change in the face or obstacles is to try to persuade other people to adopt $\dot{a}$ completely new sDcial system; or, trrough revolution, impose one by force. In such a circumstance:

We are more concerned wi th what happens when the problem that seoms to call for reform of the 800 ial order is shared by many people or is felt to be a collectivo problom. 24 
The means most relevant to this study is the one people adopt when they perceive no existing opportunities to find fulfillment in the social categories available to them, and when they can not escape into a different social environment, and that is, the development of organized movements. Organized movements can then provide internally a situation of a different social environment which the aimed-for identity change requires.

Organized movements, as alternative means of achieving identity change, provide different situations for the individual. depending upon the direction the movement takes. The direction they take depends upon hor they perceive their problems. If, for example, people who still velue the traditional goals for themselves, yet feel blocked by circumstances from achieving them, they might aim to remove the apparent oostacles. On the other hand, if the traditional methods of self-realization no longer have any value, then the individual might consider revising their social order in terms of revolution. 25 The usual consequence of thite latter situation is revolutionary movements. However, in. order to accomplish social reform or revolutionary charige some model of what is desired is necessary, thus the thira condition for identity change is most significant if identity change is to be effective. The individual engaged in social reform or revolutionary movements neods to develop modols of identity that are realistic and rewarding and 
that deal effectively with the associated emotional forces of identity change. 26

The need to have some model of what is desired in order to understand what noeds to be changed involves a consideration of the proper roles, symbols, and styles of performance that are appropriate to the new identity and also the physical and emotional adjustments to these changes. 27

In order to make a successful identity change the individual needs specific information about the new role. It is not enough to understand what one has to do to participate adequately in a new social category, one must also be eble to adopt the role successfully in a limited context (with broad overwall goals), or the change will not be meaningful.

The specific characteristics, duties, and responsibilities of the new identity must be understood. The individual making an identity change needs clearly defined standards with which to conform and models that can bear the stamp of vublic approval. People need a sense of certainty about the content of their now roles if mastery is to be. achievod.

When the whole systeri of social identities is the object of change, people have a special problem. The visions they have for themselves are likely to bo vague. They want to change, but lack a clear conception of the identities the might try to cultivate. In their discontent with themselves as they are, they are likely to be shopping argund for models and for clarifying definitions. 28 
Participation in movements provides essential opportunities for clarification of the identity the individual wishes to achieve.

Insofar as the leaders of social reform or other development movements feel it necessary to alter the system of social identities in their society, the $y$ have to be specific as to just how people are to conduct themselves. They must specify the rights and duties in social relationships, explicitig redefine the categories of person, and indicate what styles of performance will carry prestige. 2

Lack of opportunity to experiment with the new role will prevent the individual from successfully making the new identity change, even when they have the desire for change, are committed to making it, and understand what needs to be changed. Consequently, if the opportunity for experiment is available to them:

...people gain confidence in their ability to play their new roles, their sense of mastery helps to make them pleased with their new identity and with the whole identity system of which it is a part. 30

Then too,

The very process of mastery serves to heighten pooples's comritment to and acceptance of new ways. 31

In addition to understanding the specific content of a now role the person making the change must also be able to porform satisfactoridy in their new identity if the change is to be effective. In conjunction with the performance of a now role it is important that the individual have the opportunity to develop skill in applying their 
54

knowledge, thus they neod the opportunity of performance as well as the knowledge and ability to perform. 32 Movement ectivities provide the necessary opportunity of performance.

\section{POSSESSION OF TEE NEW IDENTITY}

The identity change process, to be completely successful, needs the acceptance and approval of others, "without such recognition, the best of efforts at identity change fail."33 Failure of the individual's close friends and associates to recognize the new identity can serve to invalidate it altogether. It is impossible to act in the new identity in a social vacuum, consequently, recognition and acceptance or failure of recognition and acceptance play an important part in the identity change process. When others fail to mirror a person's new identity quite often the individual will attempt to facilitate such recognition by displaying a badge of the new identity. Or, the person might obtain social recognition by involving others in some aspact of identity change. Poople are much more. likely to recognize and accept the individual's new identity If they participate in some of the circumstances with which the change is formally accomplished. 34

Further, the individual making the change is often anxious sbout accoptance and approval, and in displaying their new identity: 
...they make themselves exceedingly vulnerable to humiliation. It is a crushing blow to their new self-image and self-esteem if others respond with indifference. 35

Onco individuals have clearly in mind the identity they wish to achieve, they are anxious to obtain the symbols of the now identity in order to give it substance. Without such symbols the new identity cannot be properly presented to others nor can it be properly recognized and accepted. Further:

Once committed to changing their identities, people often have not one but several possible models from which to choose, any one of which they perceive as possessing identity features of the sort they deem desirable. 36

Any attempt at serious identity chonge must cope with the problem of attaining the recognition of others, regardless of the models chosen, or the identities desired. Once this is achieved the new identity is assured.

\section{SUMMARY}

Self-confrontation, subjection to new and trying experiences to induce change, and sharing ldentity change experiences, are all techniques employed in facilitating the possession of a new identity. Whatever techniques are employed they must lead to the individual's conceptualization of the new identity and acceptance of it on the part of others if identity change process is to be effective. 
In this thesis Goodenough's theoretical framework will be utilized then to do the following: first, to examine the desire for change among participant women and how this is achieved; two, to analyze the process involved in facilitating identity change by participants in the movement in terms of their comitment to change, understanding what noeds to be changed and knowing and mastering the content of new roles; and third, to determine the characteristic features of public acceptance or refection towards this change. Thus, in view of this framework, we can examine the characteristic experiences of Women's Liberation Novement particlpants and determine if this parcicipation con and does effect identity change, that is, if the activities of the movement are consonant with Goodenough's model of identity change process and if participation does indeed lead to change. 


\section{FOOTNOTES}

\section{CHAPTER II}

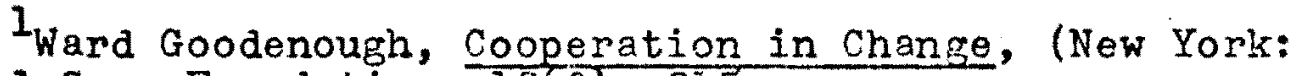
Russell Sage Foundation, 1963), 215.

2 The whole of the subsequent discussion is taken from Goodenough, op. cit., pp. 215-251.

Ibld., p. 215.

4 Io1d., p. 218.

Ib1d., p. 219.

6 Ibid.

7 Iold., p. 220 .

8 Ibid.

${ }^{9}$ Ib1d., p. 221.

${ }^{10}$ Ib1d., p. 222.

$11_{\text {Ib1d. }}$.

12 Ibid., p. 223.

13 Ibia., p. 224.

14 Ibid.

15 Ibid. , pp. 225-226.

16 Ibid., p. 228.

$17_{\text {Ibid. }}$ p. 229.

18 Ib1d., pp. 229-230.

- 19 Ibid., p. 230.

20 Ib1d.

$21_{\text {Ibid., pp. } 230-231 .}$ 
22 Goodenough, op. cit., pp. 230-231.

23 Ibid., p. 232.

24 Ibid., p. 233.

25 Ibid., p. 234 .

${ }^{26}$ Ibj.d.

27 Ibid. , p. 235.

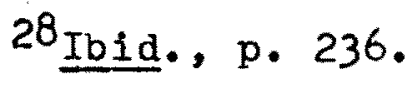

29 Ibid.

${ }^{30}$ Ibid.

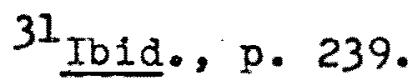

32 Ib i.

33 Ibid., p. 241.

34 Ibid.

35 Ibid., p. 243.

${ }^{36}$ Ib!d., p. 245. 
CHAPTER III

\section{RESEARCH METHODOLOGY}

This study of identity change in participants of the Women's Liberation Movement is an attempt to loarn about and describe whatever behavior is found to fall within what the participants conceive Women's Liberation to be (as well as their personal responses to it), This implies that: first, these participants conceive of a phenomenon called Women's Ilberation, that is, they have a cognitive understanding of an organization or body which they conceptualize is the Women's Liberation Movement; second, that 1t is possible to inventory their relevant conceptions concerning this phenomenon; and third, that these conceptions can be reported in a way that is both understandable and subject to precise verificstion or disproof by others who may wish to investigate this phenomenon also.

\section{PRELIMINARY STUDY}

The inftial research, which bogan in September of 1970 , was designed to provide insight and general background information on the Women's Liberation Movement as a whole. My initial method followed the traditional ethnographic approacin used by anthropologists in doing fieldwork, that is, it 
followed standard ethnographic procedures. This meant, in large part, becoming involved as a participant observer. ${ }^{2}$ Such involvement necessitated developing a comprehensive understanding of the ideas, goals, methods, and activities of the movement, and some knowledge of its historical antecedents as well. The initial phase of my research was then devoted to involving myself as a participant observer in a systematic introduction to the attitudes and activities of women in the Women's Liberation Movement.

The exploratory study included first, an extensive examination of the available literature on the subject of the Women's Lijeration Movement, including materials written by advocates of the movement, some sociological analysis of the status of women, and reading the current news items and articles covering the movement activities. This provided some peripheral exposure to the ideas and activities of the movement participants, as well as some exposure to the attitudes of the general public regarding the movement. Secondly, I became personally involved in some Women's Liberation activities and became acquainted with some local movement participants. My personal involvement into movement activities took a number of forms.

I became actively engaged in working for an abortion referral agency which was an organization peripheral to the movement but sponsored by and run with the help of Women's Liberation advocates. 3 Working with the abortion referral 
agency involved my taking a short introductory (orientation) course given by the agency. This course covered the policies of the agency, information corcerning mdeical abortion techniques, the legal and economic aspects of abortion, and the specific procedures for caring for abortion patients. In addition, the agency orientation course included information concerning the pro's and con's of abortion as an ethical question and discussed alternatives to abortions and where to get different kinds of assistance. The course was given to all poople working with the agency. 4

Subsequent to completion of the agency's orientation sessions I then assisted seven women while they obtained medical abortions. This assistance involved having them stay in my home for the period required while they received medical care, helping them to make the necessary legal and medical arrangements for the abortion, and providing transportation and staying with them while they spent time in doctor's offices and the hospital. My assistance necessitated vary close personal contact, sometimes over a period of a week, but usually only for three or four days, and included giving specific abortion counseling and birth control advice. 5

Involvement with this particularagency provided me with first hand information about one movement activity and permitted me to become acquainted with women whose interests were in Women's Liberation activities. My participation ed- 
ucated me to some of the personal problems women face, the attendant issues and social circumstances surrounding abortion, as well as involving me on an in-depth level with women with the subsequent discovery that just "boing" a woman does not "educate" one to the conditions women in general live with. In addition, I gained an understanding of one of the major issues of the Women's Liberation Movement, their demand for legal abortions and their position on this issue. However, only one client of the agency whom I personally assisted was an advocate of the Women's Liberation Movement, most of the women knew very little about the movement, and the majority held severe prejudices against it, prejudices which reflected the general public's response to the Women's Movement. 6

In addition to working with the abortion referral agency I participated in the planning of a college course designed to explain the nature of the position of worien and the nature of the Women's Liberation Movement. At the same time I participated in discussions on the Women's Movement and gave guest lectures to classes and a church group on the nature of the movement. All of this work furthered my research into the ijterature on the subject of Women's Liberation, moreover, it provided additional opportunitjes to become personally involved in working with women who are participants ir the Women's Liberation Movement. 


\section{SECONDARY STUDY}

Subsequent to my initial research I administered a general survey questionaire to some 160 college undergraduates, these included both junior college and upper division university students with a heavy concentration of junior college students (215 junior college students and 46 upper division students). 7 The survey asked two general questions: 1) What do you perceive the goals of Women's Liberation to be? and, 2) What are your personal reactions to it? This survey approach was used to obtain the broadest range of responses and emotional reactions possible, that is the range of the individual respondent's knowledge of the Women's Movement and the kind of emotional feelings they had about it, which might have been obscured in a more detailed questionaire. 8

The questionaire was designed to obtain responses concerning the students perceived goals and their personal reactions to it in order to provide a means of assessing specific aspects of public response to the Women's Movement. The questionaire also asked the age, sex, marital status, and work status of the students, and the educational background of their parents, as general information.

Further related activities in the movement involved teaching Women's Studies. The course proposal I helped to write up on a Women's Studies course was approved by ?ort- 
land Community College and I co-ordinated the first teamtaught offering there. It was an introductory survey course taught on an interdisciplinary basis to provide maxium coverage of the topic. The course was designed to study women in history, the psychology of women, the socialization and cross-cultural characteristics of women, women's legal position in this society, and their position in religious teachings and institutions, as well as the current social conditions of women and the Women's Liberation Movement. It was designed to be an introductory survey (which was all it could be with such an extensive amount of material to cover). There was one large lecture session a week devoted to a specific area and the remainder of the week's sessions were devoted to small discussion groups. The discussion groups were designed to follow the small group formation or rap group idea as it is used by Women's Liberation participants (that is, the students were divided into small groups and the groups were designed to take on the character of "rap groups" followed in forming movement groups).9 Course requirements included ar extensive range of selected rosiings, the keeping of a weekly journal (as a kind of progress report), and the fulfillment of several "mini-projects" (whose content varied depending upon the small group instructors). The mini-projects which I required of my students largely involved some form of cultural analysis from the point of view of sex role revorsal with a 
written report of the project selected for completion. The course was designed not only to teach Women's Studies but also to study the effects of such knowledge on the students. The small group formation as well as the role reversal projects, and the journals provided an excellent means of analyzing student's responses to the Women's Liberation Movement and their degree of identity involvement. The course provided an additional moans of testing and observing identity change process as it related to the movement, by analyzing attitude changes in the student's journal reports and project papers.

All of this work was a prelimination to the specific research data acquisition relative to the present study which follows.

RESFARCH DATA ACQUISITION

The aspect of my research, specific to the present study, involved conducting in-depth personal interviews with some twenty-six women participants of the Women's Liberation Movement. The interviews wore conducted in order. to determine the relationship between participation in the movement aid idertity change in participants, and to determine if this identity change correlates with Goodenough's model, and if not, iri what aspects does it differ.

An interview schealu was designed to cover all of the variables in Goodenough's rodel of identity change pro- 
cess, and the women interviewed were local participants who were selected from a list systematically compiled over a year and a half of my own participant observation in the movement. 10 The women selected were picked from this list, and selection depended upon their availability to be interviewed, but they were also selected to cover a fairly wide age range and variable levels of association and participation in the movement. Their personal occupations were also used as a selective factor in order to obtain as re. presentative a sample as possible.

Ths interviews involved from an hour and a half to several long personal conversations with the participants, and personal biographical information was obtained with each interview along with detailed information outlined in the interview schedule. The interviews were designed to obtain data concerning the women's personal motivation for participation in the movement, the degree of their participation in terms of commitment, motivation, understanding of what the wanted changed, and how they saw themselves since becoming involved. The interviews were also concerned with how the y perceived their reception as members of Women's Liberation to be received by others.

Some of the interviews were conducted with the use of a tape-recorder, however, I found using the recorder during the sessions had two distinct disadvantages: one, the respondents were more self-conscious and felt the had to have 
a "right" answer to my questions: and two, although I obtained more information I remembered less of it and had to resort to hearing the tapes a number of times after. Thus I felt information obtained with the aid of a tape-recorder was of somewhat dubious value in light of some of the respondents' attitudes. Also, because many times writing during the interview session also interferrea with the responses, much of the content of the unrecorded interviews would be noted after the sessions were concluded. The remainder of the interviews were thus conducted on an informal basis without the use of the recorder and information not written down at the time was recalled and noted immediately after the conclusion of the interview.

In addition to the formal research done by interviews, my participant observation continued because my personal involvement in the movement often necessitated additional meetings with people I interviewed, for lunch, dinner, or participation in some related activity; and in some cases, some of the women interviewed either signed up for my course on Women's Studies or came as observers or speakers. Many of the interviows produced continued personal relationships and workins arrangemants which furthered my owr participant observation studies. 


\section{ANALYSIS PROCEDURES}

Upon completion of the twenty-six personal interviews, the finaings were examined, a compilation of the details of each informant's statements were detailed as to comparable items and classified into categories in order to systematize the participation variables and objectify the data. The general categories, and items within each category, selected for comparison and systematization were drawn essentially from Goodenough's outline of identity change process. The analytical process then involved comparing these categories with the recessary conditions of identity change process presented in the theoretical framework previously discussed in order to anslyze their relationships and to determine if identity change was in fact an aspect of participation in the Women's Movoment and, if so, did it correspond to the anthropological model of identity change process.

In analyzing the fielc data the categories established relevant to Goodencugh's conditions were as follows: 1) the participants stated reasons for participation in the move: ment; 2) the specific aspects of their lives which they felt had actually beon changed as a result of their participation; 3) their degree of personal involvement in terms of felt emotional comitment and actual particjpation in various movement-rolated activities; 4) their apparent understanding of what they wanted changed, and how they saw the problems 
and solutions to this change; 5) their professed degree of understanding about the content of their new roles; 6) their perception of the acceptance of others regarding their participation; and, 7) how they say they perceive themselves since becoming involved.

These categories established from the field data were examined in light of specific items (or factors) in order to systematize the variables involved in participation and their relationship to the necessary conditions presented in the theoretical model.

Under the first category, the participants stated reasons for participation, 1) the specific reasons given for initial participation were listed, and 2) the factors of emotional identification were discussed. Under the second category, the specific aspects of their lives which they felt had actuaily been changed included the factors of: 1) aspects of the self-appraisal process, that is, evaluative and cognitive reappraisal; 2) kinds of perception and behavioral changes; and 3) stated attitude changes and degree of emotional response to self-conceptualization. The third category, degree of personal involvement, includes the following items for analysis: 1) rariations in participation activity; 2) Felt emotional responses and commitment; and 3) degree of effort made by informants in participation. The fourth category from the data was epparent understanding of what, they werted changed, and how they saw the problems and sol- 
utions to this change. Here the items considered were: 1) types of confrontation and learning experiences; 2) forms of commitment obligations, 3) apparent degreo of awareness concerning the movement as a whole, and 4 ) specific types of solutions envisioned to deal with the problems. The fifth category, professed degree of understanding about the content of new roles was examined in light of: 1) types of personal actions which resulted from participation (e.E., anti-social, radical, conformance to previously learned behavior, etc.); 2) kinds and sources of models adopted (if any); and 3) the degree of understanding of the specific characteristics of the new identity. Category number six from the field data, perception of acceptance of others, was examined in terms of the forms of acceptance or rejection of others took in regards to the informants' participation. The last category, perception of self since participation, involved a consideration of: 1) how the informants stated they felt about themselves; 2) opportunities for pero forming in theix new roles; and 3) desire to share experLences.

The categories selected from the field data and the specific factors in each category were chosen because they correspond to the theoretical iramework in the following ways: 1) reasons for participation and degree of involvement permits analysis of the cesire for identity change and how this was achievod; 2) the stated aspects of change in the 
participants lives allows for comparison of the effects of self-appraisal, kinds of confrontation experiences, and personal style changes; 3) their degree of emotional commitment ana personal involvement permits analysis of their commitment to making a change; 4) their understanding of what they want changed allows for analysis of their conception of the problems involved and the kinds of solutions utilized to deal with these problems; 5) their discussion about role content makes it possible to determine if conditions do exist in participation which requires actual changes in roles, styles, and performance and to determine the degreo of emotional and physical adjustment the change requires, if any; 6) acceptance of others enables some interpretation to be made regarding the success or failure of their participation; and 7) how they say they percieve themselves now makes it possiole to determine if identity change has occurred and if it will be lasting or permanent in its effects. Thus, the use of these categories permits analysis of specific items in Goodenough's model in order to determine if the necessary conditions he gives as necessary for identity change are part of the participants' experience, and to determine the extent to which participation in the rovement results in behaviors and responses that are consistent with the model.

In addition to the categories selected for analysis from the research data, the ege, incorie status, maritial 
status, religious and political preferences of the informants wore compared to determine if similarities existed which might have an influence on participation in the movement, and to develop correlations.

The character of the sample and a selection it represent, upon which the analysis is based, is found in Chapter IV. 11 In Chapter V the analysis of the categories selected from the field data is presented. In Chapter VI the findings in the selected categories are compared to the theoretical model and discussed in detail, variations of participation discussed, and the study's conclusions presented.

\section{SUMMARY}

The research done follows that used in ethnographic studies which consists of: the examination of available relevant materials, the consultation of some general 1iterature on the status of the subjects, personal participation in variolis related group activities, observation of individuals and groups in action, as well as the collection of statements and biographies from informants, and finally, a comparative study of the findings.

The comparative study of the findings from the collected information in personal interviews was then analyzed in. light of a theoretical model of identity change adapted from applied anthropological theory. The aim of the study was to 
determine if the participation behavior of subjects in this study conforms to an anthropological concept of identity change process. 
74

FOOTNOTES

GHAPTER III

loriginally only a year was planned to be devoted to the project, but due to teaching commitments (the usual academic's hazard) the work was extended an additional year, and while delaying the work, it helped to improve my knowledge and understanding of the Women's Movenent.

2 From the perspective of an ethnographer, participation is an absolutely ossontial part of the reasarch design. It would, for example, be folly to as sume that by simply being female one has an understanding of the conditions and problems of all other women (or any other woman).

3 There are two kinds of participante in the Wornen's Liberation Movement: 1) active members who join women's groups and explicitly identify with the movement; and 2) women who are intellectually oriented towards the goals of Women's Liberation but do not usually become active participating members in collective groups identified as Women's Liberation groups.

Hishis particular agency is Abortion Information and Referral Servics (AIRS) of Portland, Oregon. It is run by two and sometimes three paid staff members (depending upon the availability of funds), with the help of volunteers. I worked as one of the volunteer staff over the course of 1971.

5I consider all of this experience equivalent to learning the content of a new sub-culture. Certainly I learned a great deal about my own cilture I was unaware of before.

6 Their views were interesting in light of the fact. that they were being helped in large part because of efforts made by women in the Women's Movement.

7 The 115 juyior college students were largely from political science courses and therefore predominantly maie. The 46 upper division studonts were from an evening course in Poopzes end Cultures of the World, a cultural anth. course open to non- anthropoiogy majors, and the represented a fair cross-gection of adult college students. 
$8_{A}$ copy of the specific questions asked and the coding method used is to be found in the Appendix.

9A description of the small group process used is to be found in an article by Pamela Alion called The Small Group Process, (San Francisco: Suasoflopper, 1969), and reference to its usage and Rap groups in the Women's Movement are to be found on pages 25 and 27 of Chapter I of this thesis with additional source notations in footnote number 39 , page 37 .

$10 \mathrm{~A}$ copy of the interview schedule is to be found in the Appendix.

11Sample portraits are presented in Chapter IV in order to eliminate as much of the subjective factor in the observational analysis as possible, to avoid the loss of too many relevant details in the collected statements, and to provide the interested reader with some direct insight into the motivation of some of the participants in Women's Liberation. 


\section{CHAPTER IV}

\section{SELECTED INTERVIEW REPORTS}

\section{THE SAMPLE}

All of the informants in the study are white women, and belong to (or come from) middle and upper income families (tine sociological "middle-class"). The age range of the women is between ages eighteen and forty-nine; thirteen are from ages $\theta$ ighteen through twenty-five, six are from twenty-nine through thirty-eight, and seven from ages fortytwo through forty-nine. Statistics regarding marital status showed that ten were single, seven divorced, and nine were married. Two of the unmarried women were living with a man, in what one woman described as "co-habitation." Two of the informants stated they had homosexual preferences, the others wero heterosexual, but in some cases, practicing celibacy.

Religions preferences varied from practicing ChristIan to atheist, however, the majority of the informants stated they had no religious preference and when asked they indicated this meant "no interest." Eighteen of the informants listed themselves as oither agnostics, atheists, or. no religion, three were Unitarians, two practicing Protestants, and one a Buddhist for "ecological reasors." Two 
of the informants identified themselves as being "ethnically Jewish." When asked about past religious training eight of the non-religious group were former catholics, and six were former Protestants of various denominations. The two informants who identified themselves as ethnically Jewish did not profess religious beliefs.

Political preferences range widely: from one Republican to eleven Democrats, three Independents, three "Iiberals," seven Socialists, and one Communist. (Some of the informants here gjven as "socialist" stated they were "radical lert" or "radical left feminists".) Some in the latter categories stated they were former Decmcrats and two Democrats were former Republicans.

occupation categories covered a falrly broad range: from students (some part-time, some full-time and almost all working), to one executive position. Six informants listed their primary occupation as that of housewife, three worked as waitresses, six were office workers, five were college instructors (only two employed full-time), one was a nurse's aide, one an x-ray technician, one a executive. businoss manager (assistant), and one a carpenter's apprentice (with a degree Prom Harvara's School or Design in architecture).

Three of the women either had Ph.D.'s, or were working on finishing them; six have M.A.'s or are working to obtain thom; and, ell but four of the remaining group have 
had at least one year and in most cases thro to throe years of college; thus, all of the women have had some college education.

Obtaining suitable employment was a problem for many of the specially trained women and for those without special training the income level was extremely low, under or around $\$ 3000$ annually. Where women had very low incomes they depended upon either their husbands, families, or a male they were living with for support. All of the women who were going to school for more education were doing so in order to improve their job chances, and most were training for career positions in the future. (See Tables, I, II, and III, for clarification of informants' statistical characteristics.)

Following are a series of six portraits selected from the informant group to provide a more direct indication of the interview contents. The selection was made on the basis of age representation for the entire group, and form of identification with the Women's Movement. These portraits are divided into two categories on the basis of the individual's form of identification with the movement as it corresponas to already established categorios of perticipation. These two categories are labeled "Liberationists," and "Radical Feminists," respectively.1

A Liborationist is a participant who sees her participation in terms of striving for change within the oxisting social structure, and the particular jdeology of a 
INFORMANTS' (1-9) STATISTICAL CHARACTERISTICS

NO, AGE MARITAL INCOME RELIGIOUS STATUS LEVEL PREFERENCE

POLITICAL EDUCATION OCCUPATION PREFERENCE , LEVEL - + Primary

+ Primary

\begin{tabular}{|c|c|c|c|c|c|c|c|}
\hline 1 & 18 & $s$ & $\begin{array}{l}x \\
\$ 3000\end{array}$ & $\begin{array}{l}\text { * nono } \\
\text { H* agnostic }\end{array}$ & $\begin{array}{l}* \text { Left } \\
* * \text { Radical left }\end{array}$ & $15 \mathrm{r}$. & $\begin{array}{l}+ \text { Student } \\
++ \text { Flle-clerk }\end{array}$ \\
\hline 2 & 18 & $\mathbf{s}$ & $\begin{array}{l}x \\
\$ 3000\end{array}$ & $\begin{array}{l}\text { * Catholic } \\
\text { ** none }\end{array}$ & $\begin{array}{l}\text { * Democrat } \\
\text { to same }\end{array}$ & $1 \mathrm{yr}$ & $\begin{array}{l}\text { + Student } \\
++ \text { Waitress }\end{array}$ \\
\hline 3 & 19 & $\mathbf{S}$ & $\begin{array}{l}x x \\
\$ 15000\end{array}$ & $\begin{array}{l}\text { * Protestant } \\
* \text { unsure }\end{array}$ & $\begin{array}{l}\text { * Republican } \\
\text { * Hemocrat }\end{array}$ & $1 \mathrm{gr}$ & $\begin{array}{l}+ \text { Student } \\
++ \text { Nurse-81de }\end{array}$ \\
\hline 4 & 19 & $\mathbf{S}$ & low? & $\begin{array}{l}\text { * Methodist } \\
\text { * none }\end{array}$ & $\begin{array}{l}\text { Democrat } \\
\text { same }\end{array}$ & $1 \mathrm{gr}$ & $\begin{array}{l}+ \text { student } \\
++ \text { torks part- }\end{array}$ \\
\hline 5 & 19 & $\mathbf{S}$ & $\begin{array}{l}\text { not } \\
\text { given }\end{array}$ & $\begin{array}{l}\approx \text { Catholic } \\
* \text { none }\end{array}$ & $\begin{array}{l}\text { * Independent } \\
* * \text { same }\end{array}$ & $1 \mathrm{Jr}$ & $\begin{array}{l}+ \text { Student } \\
++ \text { Receptionist }\end{array}$ \\
\hline 6 & 21 & $S \& C$ & $\begin{array}{l}\dot{x} x \\
\$ 7-9000\end{array}$ & $\begin{array}{l}\text { * Catholic } \\
* \text { none }\end{array}$ & $\begin{array}{l}\text { * Democrat } \\
* * \operatorname{san} \theta\end{array}$ & $2 \frac{3}{2}$ Jrs. & $\begin{array}{l}\text { + Photography } \\
\text { Sales-business }\end{array}$ \\
\hline 7 & 22 & $\mathbf{S}$ & $\begin{array}{l}x \pi \\
\$ 12000\end{array}$ & $\begin{array}{l}\text { * Catholic } \\
* \text { agnostic }\end{array}$ & $\begin{array}{l}* \text { Democrat } \\
* * \text { Independent }\end{array}$ & $1 \mathrm{Jr}$ & $\begin{array}{l}+ \text { Student } \\
\text { ++Naitress }\end{array}$ \\
\hline 8 & 23 & M & $\begin{array}{l}x x \\
\$ 9-12000\end{array}$ & $\begin{array}{l}\text { * Catholic } \\
* \text { none }\end{array}$ & $\begin{array}{l}\text { * Democrat } \\
\text { *t:Liboral }\end{array}$ & $3 \mathrm{y} \times 3$ & $\begin{array}{l}+ \text { Housewife } \\
++ \text { Student }\end{array}$ \\
\hline 9 & 23 & $D \& C$ & $\begin{array}{l}x x \\
\$ 9-12000\end{array}$ & $\begin{array}{l}\text { * none } \\
\text { * Ljberal- } \\
\text { Protestant }\end{array}$ & $\begin{array}{l}\text { *onservative } \\
\text { Hore Liberal }\end{array}$ & $I^{1}$ yrs. & $\begin{array}{l}\text { + Housewifo } \\
++ \text { Student }\end{array}$ \\
\hline
\end{tabular}

No. = Informant's Interview Number $S=$ single $M=$ married $D$ divorced $x=$ Personal Income $x \pi=$ Family or Joint Income $\quad C=$ Cohabitation 
INFORMANTS' $(10-18)$ STATISTICAL CHARACTERISTICS

$\begin{array}{llllll}\text { NO. AGE } & \begin{array}{l}\text { MARITAL } \\ \text { STATUS }\end{array} & \text { INEVEL } & \text { RELIGIOUS } & \text { POLITICAL } & \text { EDUCATION OCCUPATION } \\ & & \text { PREFERENCE } & \text { PREFERENCE } & \text { LEVEL }- & + \text { Primary }\end{array}$

\begin{tabular}{|c|c|c|c|c|c|c|c|}
\hline 10 & 24 & D & 奀3000 & $\begin{array}{l}\text { "Norced" } \\
\text { Protestant } \\
\text { "*athelat }\end{array}$ & $\begin{array}{l}\text { *Middle Demo. } \\
\text { * *hanging }\end{array}$ & $1 \mathrm{gr}$. & +clerk-typist \\
\hline 11 & 24 & $\mathbf{s}$ & $\underset{\$}{\$} 3-5000$ & $\begin{array}{l}* \text { none } \\
* \text { none }\end{array}$ & $\begin{array}{l}\text { * Iiberal } \\
* \text { Radical }\end{array}$ & $\begin{array}{l}\text { B.A. } \\
\text { Grad. } \\
\text { work }\end{array}$ & $\begin{aligned} &+ \text { Part-time } \\
& \text { Instructor }\end{aligned}$ \\
\hline 12 & 25 & $\mathbf{s}$ & $\begin{array}{l}x \\
\$ 5000\end{array}$ & $\begin{array}{l}\text { *Protestant } \\
* \text { none }\end{array}$ & $\begin{array}{l}\text { * Democrat } \\
* \text { Liberal }\end{array}$ & 2 yrs. & $\begin{array}{l}\text { +office worker } \\
\text { Telephone Co. }\end{array}$ \\
\hline 13 & 25 & $\mathbf{s}$ & $\begin{array}{l}x \\
\$ 3000\end{array}$ & $\begin{array}{l}\text { * Catholic } \\
\text { * none }\end{array}$ & $\begin{array}{l}\text { * Democrst } \\
\text { * Communist }\end{array}$ & $2 \mathrm{yrs}$. & $\begin{array}{l}+ \text { Waftress } \\
++ \text { Student }\end{array}$ \\
\hline 14. & 29 & $\mathrm{D}$ & $\begin{array}{l}x x \\
\$ 50000\end{array}$ & $\begin{array}{l}* \text { none } \\
* * \text { none }\end{array}$ & $\begin{array}{r}\text { *Socialist } \\
\text { **Radicel- } \\
\text { feminist }\end{array}$ & $\begin{array}{l}\text { M.A in in } \\
\text { Archi- } \\
\text { tecture }\end{array}$ & $\begin{array}{l}\text { +Carpenter's } \\
\text { Apprentice }\end{array}$ \\
\hline 15 & 30 & $M$ & $\begin{array}{l}\mathrm{xx} \\
\$ 20000\end{array}$ & $\begin{array}{l}\text { * \& * } \\
\text { Ethnically } \\
\text { Jewish }\end{array}$ & $\begin{array}{l}\text { Radical-Soc. } \\
\text { Fominist }\end{array}$ & $\mathrm{Ph} . \mathrm{D}$. & $\begin{array}{l}+ \text { College } \\
\text { Professor }\end{array}$ \\
\hline 16 & 33 & $\mathrm{M}$ & $\begin{array}{l}\pi \pi \\
\$ 10000\end{array}$ & $\begin{array}{l}\text { *Protestant } \\
* \text { none }\end{array}$ & $\begin{array}{l}\text { * Democrat } \\
* \text { same }\end{array}$ & $3 \mathrm{grs}$. & $\begin{array}{l}+ \text { Housewife } \\
++ \text { Student }\end{array}$ \\
\hline 17 & 37 & $M$ & $\begin{array}{l}x x \text { over } \\
\$ 12000\end{array}$ & $\begin{array}{l}\text { *Protestant } \\
\text { Hindifforent }\end{array}$ & $\begin{array}{l}\text { * Democrat } \\
* \text { Radical }\end{array}$ & $\begin{array}{l}\mathrm{BA} \text {. in } \\
\text { nursing }\end{array}$ & + Housewife \\
\hline 18 & 38 & D & $\stackrel{x}{\$ 9000}$ & $\begin{array}{l}* \text { Catholic } \\
* * \text { none }\end{array}$ & $\begin{array}{l}\text { * Democrat } \\
\text { * *Socialist }\end{array}$ & $\begin{array}{l}\text { B.S. \& } \\
\text { grad. } \\
\text { work }\end{array}$ & $\begin{array}{r}\text { College } \\
\text { teacher }\end{array}$ \\
\hline
\end{tabular}

No. = Informant's Interviow Number $S=$ single $M=\operatorname{married} D=$ afvorced

$x=$ Personal Income $x \pi=$ Family or Joint Income $\quad C=$ cohabitation 
TABLE III

INFORMANTS ' (19-26) STATISTICAL CHARACTERISTICS

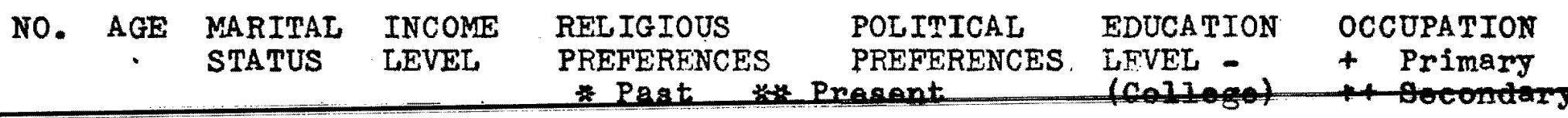

\begin{tabular}{|c|c|c|c|c|c|c|c|}
\hline 19 & 38 & M & $\begin{array}{l}x x-o v \in r \\
\$ 15000\end{array}$ & $\begin{array}{l}\text { * Methodist } \\
\text { * Unitarian }\end{array}$ & $\begin{array}{l}\text { *Disillu- } \\
\text { sioned Demo. }\end{array}$ & $1 \mathrm{yr}$. & $\begin{array}{l}\text { +Accounting } \\
\text { Clerk }\end{array}$ \\
\hline 20 & 42 & $M$ & $\begin{array}{l}\text { xx - over } \\
\$ 12000\end{array}$ & $\begin{array}{l}* \& * * \\
\text { Ethnically } \\
\text { Jewish. }\end{array}$ & $\begin{array}{l}\text { * Indepen- } \\
\text { dent }\end{array}$ & $\begin{array}{l}\text { B.A. \& } \\
\text { grad. } \\
\text { work }\end{array}$ & $\begin{array}{l}++ \text { Housewife } \\
+ \text { Housewife } \\
++ \text { Student }\end{array}$ \\
\hline 21. & 43 & $D$ & $\frac{\pi}{\$ 5-7000}$ & $\begin{array}{l}\text { * Episcopal } \\
\text { * Unitarian }\end{array}$ & $\begin{array}{l}\text { * Democrat } \\
\text { * same }\end{array}$ & $\begin{array}{l}\text { B.S. \& } \\
\text { grad. } \\
\text { work }\end{array}$ & $\begin{array}{c}\text { + Graduate } \\
\text { student }\end{array}$ \\
\hline 22 & 43 & $D$ & $\begin{array}{l}x \\
\$ 3000\end{array}$ & $\begin{array}{l}* \text { Protestant } \\
* \text { Buddhist }\end{array}$ & $\begin{array}{l}\text { * Republican } \\
\text { * Socialist }\end{array}$ & Ph.D. & $\begin{array}{l}+ \text { Teacher } \\
\text { Part-time }\end{array}$ \\
\hline 23 & 43 & $M$ & $x_{\$ 15000}$ & $\begin{array}{l}\text { * Instarien } \\
\text { * seme }\end{array}$ & $\begin{array}{l}\text { * Republican } \\
\text { same }\end{array}$ & M.A. & $\begin{array}{r}\text { + College } \\
\text { teacher }\end{array}$ \\
\hline 24 & 45 & D & $\begin{array}{l}x \\
\$ 7000\end{array}$ & $\begin{array}{l}\text { *Protestant } \\
* \text { maybe }\end{array}$ & $\begin{array}{l}\text { *Democrat } \\
* \text { same }\end{array}$ & 2 yrs. & $\begin{array}{l}\text { X-Ray } \\
\text { technician }\end{array}$ \\
\hline 25 & 46 & M & $\begin{array}{l}x x-\text { over } \\
\$ 20000\end{array}$ & $\begin{array}{l}* \text { Catholic } \\
\text { none }\end{array}$ & $\begin{array}{l}\text { * Republican } \\
\text { * Democrat }\end{array}$ & $\begin{array}{l}\text { working } \\
\text { on } \mathrm{Ph} . \mathrm{D} \text {. }\end{array}$ & $\begin{array}{l}\text { + Asst. Eus } \\
\text { Managor }\end{array}$ \\
\hline 26 & 49 & M & $\begin{array}{l}x x \\
\$ 9-12000\end{array}$ & $\begin{array}{l}\text { *Protestant } \\
\text { * Interden- } \\
\text { ominational }\end{array}$ & $\begin{array}{l}\text { * Democrat } \\
\text { * same }\end{array}$ & $\begin{array}{l}\text { some } \\
\text { colleged } \\
\text { Business }\end{array}$ & + Housewife \\
\hline
\end{tabular}

No. = Informant's Interview Number $S=$ single $M=$ married $D=$ divorced

$x=$ Porsonal Income $x \bar{x}=$ Famiiy or Joint Income $\quad c=$ cohabitation 
Liberationist holds that: 1) men are not the oppressors, the social structure is; 2) the present economic system discriminates against women, but more and greater job opportunities will correct this; 3) it is most important to convince men of how women are oppressed for men are oppressed by their roles too; 4) everyone will be lib. erated if sex-role stereotyping can be eliminated and women's present social and economic condition improved, hopefully under the existing system, but it not, porhaps under socialism. However, the existing electoral system should be the means utilized to obtain equality for women.

A Radical Feminist, on the other hand, is one who: 1) sees all men as the oppressors; 2) believes all societies are male supremist and the basic problem is a psychological power struggle; 3) holds that the total existing social system must be replaced; 4) that women must take privileges from men by force if necessary ana eliminate their power positions altogether, that nothing short of an all-out revolution and the establishing of some sort of anarchist-socialist society will produce equality for. women.

This dichotomization is somewhat of an over-simplification as beliefs of various individuals may range on a continuum from Liberationjst to Radical Feninist; thus, members subscribing to one ideology or the other often overlap in terms of views. However, the categories are 
used here to help present the sample portraits of informants from the study, and this categorization is a useful conceptual structure with which to depict the participants interviewed in this study.

The following portraits are prosented alternating a "Radical Fominist" with a "Liberationist" and in terms of chronology from youngest to oldest.

\section{PORTRAITS FROM THE SAMPLE}

1. Karen ${ }^{2}$ is age eighteen, single, self-supporting, and a second year college student. She works in an office as a. file-clerk, parti-time during school and full-time summers. She shares a house with some other women, all about the same age, and all active in some form of Women's Liberation activities. Her annual income is under $\$ 3000$. She had no special religious training in her background and she classifles herself as an agnostic. In terms of political preferences she lists her past preference as "left" and present as "radical left," but says she usually follows Democratic candidates in elections, and works for Dernocratic candidates. during campaign years. She has a steady male companion whom she says is twenty-six, single, employed in business, has a college degree, no religious inclinations, and conservetive political pref'erences.

Karen's father was a policeman with a high school education, Catholic background, and conservative political 
leanings. He died when she was quite young. Her mother is a teacher, has a B.A. degree (acquired subsequent to the father's death), no religious preferences, and is "left" politically. The family income is not given.

Karen says her involvement in Women's Liberation followed a number of experiences during her years in high school. In the first year of high school some women already in the movement tried to interest her but she was put off by their lesbian association with the movement and the fact that it did not have much meaning for hor at that time. She was active in civil rights-related activities and Black Liberation, then she became involved in anti-war activities, peace demonstrations, and finally Gay (male) Liberation. About this time, she says:

...it hit me about women, the high school
boy/girl shit and the little princess crap,
and then understanding about women followed.
Participation was directly related to the activities she was engaged in and the people she was involved witho The "woman as object" theme of Women's Liberationists began hitting home in her role behavior with boys. She was under considerable pressure to "get a boyfriend," to have some sexual experiences, to dress right, to be the "right" weight, and in general "be hip," all in order to meet the social pressures of being able to attract males and to be "popular" with her peers.

Her response to this pressure was resistance and be- 
cause of the associetions formed in her previous political activities this resistance led to the adoption of the attitudes of Women's Iiberation and getting involved with other women.

Women's Liberation, to Karen, means a number of different things: liberation from all stereotype sex roles; equal status to men, but not to do the "same shit as men"; the formation of a now society with "elimination of all garbage" (e.g., war, racism, sexism, and nationalism); need for people to obtain political power. It also means that women should have equal pay for equal work, to hold political positions in larger numbers and positions of authority. In addition, Women's Liberation offers, for Karen, a means to end sexist advortising, and sexism in the entertaining arts, literature, and in education.

There have been a number of changes in her life-style since becoming a participant, both physical and psycholog: 1cal changes. Foremost among these, she says, is her awareness of women as people. She says she now "tends to sympathize more with women over any mar. $n$ She listens more to women and no longer "puts them down" for doing the sociall construed "dumb woman" things.

In terms of personal changes she has stopped wearing make-up and dressing to "attract men." She noted that thia ... surprises me to discover that I didn't need it in the first place, because people still re- 
act to me the same way they did before. Now I don't have to be a sex-object in the way I dress.

She states, however, that:

I'm torn between what I understand now and what I've learned to do before. It's very difficult. $I$ tend to be angry all the time, tend to be rude, obnoxious, and very crass to men, espectally if they treat me like "another female." The male's: sex-object attention makes me very angry.

She sees herself now as being stronger, that she no longer has to "impress some male"; "meaner... I know now that what I'm doing is right and I don't have to apologize for what I am." She says she is most concerned about her own attitudes and presents herself as aggressive and independent, mainly because she feels a growth in self-confldence.

She feels it is necessary to get involved, and "Involvement means converting other women, talking to them, getting them involved." She says, "women need to be talked to so they can be made arare of their own oppression." Involvement to her means education, however, she states that she does not think she is "all that liberated," and sho thinks she "has a long way to go." The involvement, for hor essentially means educating other women.

Although she is primarliy concerned with sharing her experiences with other women, she says she will talk to men about Women's Liberation "only if they're willing to listen, and only if they're willing to try to understand."

In terms of how her participation is accopted by 
others she says that although her mother is sympathetic to the movement and quite liberal in her attitudes she considers Karen's behavior "rude to men." Karen says that in the orfice where she works "sometimes it upgets women I talk to as well as men." She says she modifies the tone of her conversation in such situations so as not to alienate women; she doos not talk about being a Woman's Iiberationist, instead she talks about woman's oppression in general. About her work situation, she says:

...all the women in the office act like little children; they have "put-on" voices and "put-on" mannerisms, everyone of them, and everybody trys to out do each other. Women in the office spend hours and hours talking to men about nonsense stuff, and everyoody's talking about who's getting married and who's had a baby and I can see all the sexist implications of this behavior and I want to say something, but if I say something as simple as "Why don't you change your kid's diapers?" to a man, they stop talking to me. And the homely women IIn the office 7 don't bother to compete. They are sick or depressed and always taking pillo and having stomach problems. Claude /the office manager 7 is constantly complaining about those "dumb women."

Karen says she finds it very depressing bocause she understands why the women feel compelled to act the way they do and why the men get so "up-tight" about doing things differently.

In terms of old friends and personal relations, there seems to be less difficulty in understanding and acceptance., Her old friends are those from high school who participated in tho same political areas as Karen and, her close male - friend wants to ratntain their relationship, and therefore, 
struggles to understand her position. It would seem, from our conversations, that she is educating her male companion to the Ideas and values of the Women's Liberation Movement, as she understands them and this helps maintain their relationship.

As for her satisfaction with the movement, she feels she herself needs more understanding of how sex-role stereotyping affects her life and that she needs to get involved in women's prison reform. In terms of her perception of other women in the movement she says:

...there are too many upper class women playing games, catering to mon and playing poljtics; if they'd stop playing politics and get down to the issues of the radical women maybe something would get done. Women in the movement aren't enough together. They have to get it together and stop competing with one another, which they've been doing all along. As for the rap groups, talking about personal problems is all right when they first get involved, but after they need to move on to the larger social issues; abortion, women in prison, men, political rights, and sex discrimination at all levels. Women in the movement are constantly catering to men, always concernod about men, the same with Gay /male7 Liberation, they're too busy screwing to get down to businoss to form a movement.

Karen is very positive in her attitudes, and very much an adherent of the movement. She thinks she wants to be a lawyer and is working her way through school with that in mind. She has been active in working for political candidates in the past and at present she has organized a woman's rap group and is working with it. She says, however, she feels her own participation in the movement is "very low." 
She supplements her information about the movement by reading, and she writes short articles for underground women's publications. Her attitude towards the movement is best described as one of dedication.

2. Sally is nineteen, a single college student, working part-time as a nurse's aide in a convalescent home. Her parents are both teachers, her father has a master's degree and her mother has five years of college, both are Preabyterians and Republicans and the family income is over $\$ 15,000$. She lives at home when in Portland and in a dormitory when at school.

Sally feels she has been generally angry and frustrated with the existing status quo for a long time, but began putting it together when she got a job and started college. She was, and is, interested in organizing women's studies programs and in order to do that she has had to educate herself in the values and ideas of the Women's Movement. (She attends a college where there are presently no courses in Worlen's Studies being offered.) Two things in particular devoloped her interest in the movement; first, a difficult emotional relationship with a young man; and second, her present job. She became involved with a boy and discovered in the course of their relationship that ho was also invol-. ved with another young women. Pressured by the "new sexual revolution" and the fact that she did not want to break off 
the relationship she tried to maintain it even though his infidelity to her was emotionally upsetting. At the same time her sister was involved in a similar situation. Also, Sally found employment in her present job, all of which was her "confrontation with this "marl's world" which oroved to be quite disturbing. On the job, she discovered that it was "male owned and male governed in terms of final decisions," and the women employees worked for very low wages; "the ownner drives away in a Cadilac;" and in her relationship with her male friend, "he makes all the decisions" about when he sees her, or even if he sees her.

The accumulative effect of these situations led to interest in the Women's Movement which was (and is) receiving quite a lot of attention in the news media.

... at the convajescent home where I work, though it is owned by a man, it is really run and governed by the head nurse as far as the patients and aides are concerned, that is, care, hiring and firing, dietitics, and so on. The evidence is more indirect than that, some of it is obvious, the owner is a man and he does have final control and authority over everything. The biggest thing is in the women who work there, women who largely because of their age; they're either too old or too young; their looks, not "pretty" or overweight, or other things, can't work at anything else and finally get this lower paying job that hires only a pair of hands and usually always women's hands, or there's also those of us with college training who could he doing other jobs except we know there's no sense even aoplying because they're already taken, by men. It's not that the same labor-type jobs don't exist for men but they are all union controlled with seniority and approval and not so low-paying. We make even less than waltreases bocause we can't play trie sex game for tips. And when hospital staffs try to organize for bettor wages 
society not only doesn't approve but says it's wrong. Damnit, things have to change. Nobody who works with the sick could possibly want to strike and leave, but there has to be another way; myway, I'm looking for some answers. When I find some of the answers I can talk to people and get them started. But the more I think and see and learn the more questions $I$ get and the angrier I become. The more $I$ develop as an aware woman and feel freer inside myself, the more I feel trapped by things outside me, the more I feel my oppression, not my freedom.

In terms of her emotional relationship with her young man she says:

I know he has another woman, but is interested in me. I have trouble accepting this other womars as a sister and a friend. By the way, I've never net her, he keeps us apart somehow. But, she really does not threaten my love for him or my desire for security because I don't want a declared, marriage-type relationship but rationally prefer a more open-ended one. Emotionally, though, I would really like to know there is still somebody male around that a woman can have a halfway decent relationship with. I find it somehow hard to take emotionally, that he point blank is not here when I would like him to be with me. I am trying desperately, and probably not succeeding, to keep my emotions from him. I don't want to play games. He plays the other woman against you ... I refuse, as much as possible, to play this game, but the other choice I have is to lose the relationship and I'm not ready to do that yet.

And men wonder why we become so angry! Women do what they have to do to exist, even as half persons, second-class, and they're doing exactly what they've done for thousands of years. I don't want to Iive as a half person, as second-class, so I figure by knowing myself as well as I can, especially as a woman, by talking to other women, and learning and acting with othen.worien, and by teaching and showing men by actions end confrontations, maybe we can bulid a better society. We have to, though men aren't really as importent as the womon at this point. If we can't solve these hurnan relation problems how can we expect to solve the problems of the world?

Sally is interested in self-defense for women, and for 
women be educated into the ideas of the movement. She says her own involvement has made her more conscious of other women and their problems, more self-confident in her ideas, and especially determined to "push the woman's thing." She says she is more out-spoken, more angry, and less afraid to display her anger, especially to men. Her parents "tolerate" her behavior, her "unfeminine" dress, and her attitudes because, as she puts it, they think she is going "through a phase." She seeks friends, women friends from among interested Women's Liberationists, and finds in general, a great deal of hostility to the idea of women's equality outside of this circle of women.

She is involved in organizing women on her collego campus, and at work, into lecture courses and rap groups; she is also especially concerned with educating the young men she associates with. Overall social reform seems too "radical" to her at this point, she is more interested in changing the attitudes of people:

\footnotetext{
...true this is a long slow orocess, though it is accumulative in effect and moves faster and faster. Because it is so slow it creates angry, frustrated women like me. Sometimes faster, more shocking methods are more effective. I still don't seom to be coming up with many. answers.
}

3. Norma is twenty-nine years old, divorced, has a degree. in architecture, recently obtained a job as a carpenter's apprentice, and lives in a women's collective. She comes. 
from a fairly well-to-do New England $f$ amily and has an independent source of income. She has no religious background and reflects the socialist political preferences of her parents.

Her interest and involvement in the Women's Movement was the culmination of a series of difficult personal experiences. She had married quite young (in part to escape the family home); her marriage followed several years of living with the man she ultimately married and the marriage promptly failed. Her husband left her for another woman while she was going to graduate school. Moreover, the depression which followed led her into several equally unfulfilling personal involvements with men. For awhile, during her last years in graduate school, she was under the care of a psychiatrist which, for her, "was a total waste of time."

Psychologists are still into trying to get the person to fit the scciety, as though it was their /the patient'a/ fault, not society's.

About this time she "split" from a living situation with a man whom she had lived with for about a year, "but never really cared for," and moved away. Subsequently, $a$. woman friend invited her to attend a rap group session, and she moved in, about this same time, with another woman. Participation in the rap group helped her to understand Women's Liberation, and she remained in the group for a: year although she complained that it was never a totally satisfactory situation. 
The women were into personal experiences but dealt with them from a totally intelectual perspective, and they weren't very political or interested really in gotting political. I tried suggesting we do other things, anything, go to the beach, have dinner together once in awhile, or spend a week-end someplace as a group, but nobody took me up on any of my suggestions.

Participation did, however, help her to adjust to some of her personal problems. She had been:

...hung up on the "feminine trips" being overweight, how I looked. It took me a long time to get over wanting to bo noticed on the street, not wanting to be considered "unfeminine."

(It is interesting that Norma thinks of herself as being "overweight" for it is not how one would describe her.) In addition, participation in the rap group helped her to deal with some of the problems she had been seeking the psychiatrist about, why she could not deal with men, her sexuality, and her general feelings of fmustration.

About the time of her rap group involvement she had a sexual rel ationship with another woman which had jeen very difficult for her to handle emotionally:

The situation blew my mind, I though everyone on the street krew. But in the group I began to consider it in a different light. If we've been had by all the other things in our lives, why not about the nature of our sexuality?

She left the group after a year because "it dian't seem to be going anyplace." However, she did have much better feelings about herself as a person. She folt much more self-confident, the concern about how she looked had 
diminished, she was no longer afrald about being homoserual, (although she thinks she is probably bisexual rather than homosexual), she is able to act out her anger and frustration with the wrold and no longer feels guilty about it as a personal problem. Moreover, she has become radically political. Her concern is getting other women involved, though she tried at first to talk to men she is no longer interested primarily because she believes it is "impossible to deal with their arrogance."

And, my gay male friends have the same "macho" hang-ups about themselves and women. They have to pay the check or open doors. Crazyl And straight men express real fear when you tell them youre gay.

Her aim is to develop in other women increased awareness about politics and the need for political organizing.

Women have real potential power for a revolution if they get it together. They need to get together, just women. Besides, there's one in every home. And men have to be forced to relinquish power.

For Norma, Women's Liberation means total social change, elimination of capitalisn and sex-role stereotyping, of male domination and authority systems. In addition, she says it means the possibility of seeking personal fulfillment in whatever kind of sexual relationships are moaningful to tho individual. She seems to have clearly in mind what specific aspects of existing social conditions noed to be changed, and, she thinks she is loarning more all the time. She is not optimistic about the ruture success of Women's Libera- 
tion, however:

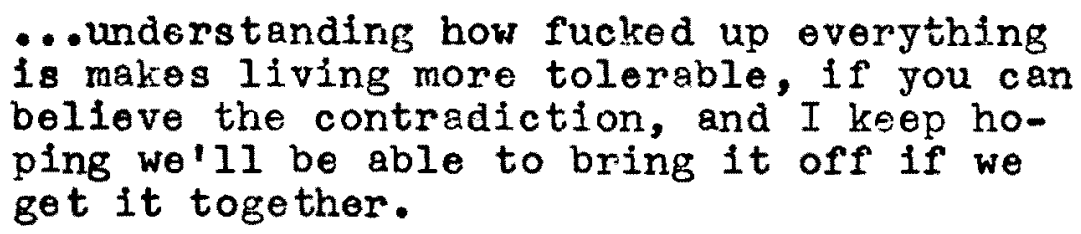

Her participation in the movement is not difficult from the stand point of acceptance from her family and friends, but it does present psychological problems on job situations and her solution to the job situation is to find work among compatible people. Because she has an independent source of income she has a greater cholce in terms of jobs, therefore it is not really a major problem there oither.

4. Elleen is thirty-seven, married with two teenage chilaren, and living with her husband and family. She was raised in a Protestant falth but says she is "indifferent" to religion; she is a Democrat (married to a conservative Republican), has a degree in nursing but is not omployed (by cholce). Sho lists her occupation as housewife, and the family income is over $\$ 12,000$. Her mother (now dead) was a housewifo with an eighth grade education; and her father is a millworker, high school education, and both parents were Republicans. She has a younger sister who works as a librarian in a college in the east and who has been an influence on her participation in the movement. Eileen went to college right arter high school, mot 
her husband while working as a nurse, married, got pregnant, and took up the fob of housewife fulltime.

Her slster alerted her to the Women's Movement and Eileen began to investigate it on her own through books, magaziries, and various articles covering it. Exposure made her aware of aspects of her family life as well as that of women in general which fit what women in the movement were complaining obout:

In my home my father controlled all of the money. He gave my mother an allowance and by doing so he was able to control my mother completely. She was trapped and the less education a woman has the more subservient she is. My mother always wanted boys. I never wanted to be like my mother My $f$ ather encouraged both my younger sister and myself to go to school and he pushed us to achieve.

In addition to helping her understand the situation in ker family home the exposure to the Women's Liberation ideas helped her to understand some of her personal experiences.

I had really dresded getting married. I remember I broke the first engagement I had because the boy made me feel like I was boing controlled. Later I met my husband, wo narried and al though he didn't realiy want to have children I got pregnant right away.

Eileen says her husband is quiet, non-aggressive, and moro dependent as a personality than she is. For her the Women's Movement involves personal liberation and her husband is central to tho issue.

Women's Liberation is necessary and important. It's needed like uniors so women don't become obsolote.

Hor participation is on an individual lo vel, it means 
involving both women and men, educating them to the ideas of Women's Liberation and to the present situation of women in regards to male domination. Her participation is also directly related to her marriage and trying to make it succossful. She says she:
...understands problems aren't my fault and
I'm more comfortable. One person can't do
all the giving. Because I feel better about
myself, my marriage is growing and I can push the relationship more because I'm more secure and more tolerant.

Eileen says she feels a growth in her own personality and consequently is learning not only to handle her marriage better but also her in-laws, whom she says tend to dominate her husband and their marriage as well.

Her participation at this point is essentially an ideological one so consequently it is not a problem at home. She says she is quite comfortable and where her personal friends are concernod when there is any controversy she is silent. She says she is also comfortable in her udierstanding of the values and goals of the Women's Morement as a whole. What she has derived from her exposure to the readings and various moetings she has attended is that women are not obliged to play roles. She attends occasional lectures on the Women's Movement whon it does not interfere with her family obligations. She says the major change which has come about. for her is that she has achieved a great deal of self-confidence and a better understanding of her world. Consequently, 
she feels better able to cope with her l1fe. She does not want to pursue any other career than that of housewife and the Women's Movement has helped her to deal with it more offectively.

5. Maureen is thirty-eight, divorced, lives with her two teonage children, and works as a teacher. Sho was raised a Cathollc but gave up her religion when she was quite young. Her political preferences are Socialist:

but since that's not possible under the present democratic system, I vote anyway, usually for the so-called Democrats.

Her mother was a housewife and part-time office worker with a high school and special stenographer education. The mother was also a "sometimes" Catholle and a Democrat. Her father was a minor official for a business rirm, and had an oighth grade education, no religious preferences and was registered Democrat. Maureen quit high school to get married and started college whon her children were in school. She divorced her husband because of the incompatibllities which deepened as a result of her continuing education. Sho had a second brief marriage "which didn't work any better for the same reasons."

She became involved with the Women's Movement as a result of a developing awareness, and:

...bocause I've been rejecting things all my lifo why not "woman's place?" I gave up Catholicism at about ofghtoen, and I'd been a true believor. I dislike conformity especially when it's imposed 
on you from tho outside. I came to understand about my racism as I developed a better understanding of its existence, and $I$ gave up my naive beliefs in our democratic system when I began to understand the nature of politics, so why not women? Naturally I'd come to women last, everybody does. Women weren't even recognized as "persons under the law" until this year $/ 19727$ and that distinction was made after BIacks, Indians, children, Hick Wo or Wick Ho, (I can't remember which), Running Bear, (I guess he's Indian), and finally women, last and loast. So, I don't really feel I'm out of step discovering women last.

She says she became interested in the Women's Liberation Movement when she discovered she did not grasp:
... What all the fuss was about, and since I'd
leamed from past experience the ro was usually a fire under the smoke I decided to find out what caused 1t. I was already aware of the employment and economic problems wornen have, but I realizad all the hollering involved much more than that and $I$ had to find out what it was.

Participation in the movement first involved understanding the issues, reading and talking to other women, then she had a chance to help form a rap group which she participated in for a short while.

The rap group was interesting and I met some fantastic women, but I found I was more interested in their problems (I'd divorced most of mine), and $I$ wanted to do something political,

so I dropped tho rap group whon I had a chance

to get into a women's political action group. By that timo everjbody was ready to do something different anyway.

To Maureen Women's Liberation moans "human Iiberation," an end to placing poople in class and caste atructures; it also means an enc of mele power and will come about only 
through revolution.

The war which really noeds fighting is the battle to take power from the men, everywhere, and such a battle means women fighting men, but it's not very likely because women have too much to unlearn to ever get together enough to square off agajnst men. Besides, if they could unlearn everything that helps oppress them the battle would be won automatically.

She says that not a great deal has changed in her life overtly since becoming a participant; she dresses much the same, has the same life stylo:

except I no longer have much to do with men if I can help it. Sure you can say thej'ro oppressed too, but it's difficult to be sympathetic when it costs me money and privileges and they hold all the clubs.

Her home situation is much the same, her personal friends aro now women involved in the movement and on the job:

my male colloagues tend to avoid me. People accept me who are sympathetic to the movement and those who aren't and know I'm involved rejoct me.

There have, however, been a significant number of psychological changes since becoming involved; her attitudes to wards women is different, sho says she sees them as poople:

I never really saw women before, like whites don't see blacks, they're there but they don't register. And I seo men differently too. In the past I served as an object for men. I realizo niy rolationships with men have been exploitive, unequal, frustrating, economically necessary, all of which was very nicely hidden under the label "love." Lore is not possible under such conditions and that means it's not possible at all, until the conditions change for women. 
In terms of sharing experiences about the movement

Maureen is most concerned vith the education of women:

Women must come to the understanding that they have value and not as objects for men, but as people who have a world to restructure. Talking to men is a was to of time, the don't listen, after all we're "just women," and for them it's not inportant what women get excited about, unless what women get exclted about is them. For men the only things that are important are powar, money, war, killing, violence, destruco tion, and flattery to their egos, certainly not iffe or love or tenderness, not if the present world situation is any indication of what they value.

Part of the psychological changes she fools have taken place in herself are an increase in self-understanding, a more profound understanding of the nature of people, a greater feoling of self-confidence and self-assurance and a sense of dedication to the movement; although she says revolution is necessary she is very pessimistic about its ever happening. As for her own level of participation she feela It is "inadequate," and her personal understandirg is "not complete," however, "it increases all the timo."

Women have to utilize whatever means are available to them to improve thoir lives, traditional political action, or takirg legal

action in cases of discrimination, or even violent actions if the situation calls for 1t. But, using the traditional avenues open to us won't get rid of male domiration and that's the problom we face.

6. Florence is forty-8ix, a native of Portland, married with six children and working os an assistant business manager for a large firm. She comes from a fairly well-to-do 
family who own their own business. Both of her parents work for the firm they own, they are both practicing catholics and Republicana, while she is a Democrat. Over the years she has maintained close ties with her family. Her husband is a psychologist (her marriage was frowned on by her famtly for a long time after she married); they have six children ranging in ages from 22 to 12 . The size of her family was. not the consequence of her personal wishes, but the result of her Catholic upbringing and advice from a priest "to accept her situation as a woman and conform to your husband in everything you do." She gave up her religion after such continued advice. At the present time she is working and golng to night school to complete a Ph.D. In business, and she is planning on leaving her husband soon. (At the time of the interview the separation was planned for the following month and had been arranged for some time.)

Florence has always viowed hersolf as something of a rebel, her marriage to a man whom her parents disapproved of was an initial indication of throwing off parental control. She worked prior to marriage and then returned after the . birth of her last chidlren (twins). She loft the Catholic Church and took her children out of Catholic schools which was an "extremely derlant gesture" towards hor family and she seos it as such for herself. Then she started to read Dr. Mary Daly, "Women and the Catholic Church," and that was her introduction to Homen's Liberation. 
I discovered it wasn't just my problem. Then

I read Betty Friedan's The Feminine Mystique, and related instantly to the content because my life and my marriage situation were extremely frustrating, no abortion, no birth control, and the "old German" mentality of my husband.

Her level of frustration with her marriage was "extremely high," but she found old habits hard to break.

I've always been aware of the patronizing attitude of men, and my husband will say, "but, I've always let you do what you wanted to do," and be so mystified about why I'm angry. My husband's family is German and he's a first generation American and my husband's mothor's status in the family was impossible. She wanted her kitchen painted for years, her kitchen, where she worked like a slave for them, and nobody would even paint her kitchen. Her husband constantly derided her... But she learned to drive at age 62 in spite of it all. She died at 64 of a heart attack.

When Florence became actively involved in the movement, she organized a Women's Caucus for polftical action and to improve employment opportunities for women locally.

I don't picket, but I'm gl ad other women are willing to do it, bec ause women's employment situation is terrible and picketing is sometimes necessary. On my job women get hired at $\$ 350$ to $\$ 375$ per month, men get $\$ 550$ to $\$ 600$ with the same level of education and qualifications in many cases. starting salary t... is $\$ 550$ and we're told "that's good for a woman."

She also protests the automatic hiring of men over women, especially when women are often better qualified.

A professor at P.S.U. recently told me "no woman has ever passed my course," and he simply stated he did not like womon, and didn't think they had a place in higher ed- 
ucation. How can you avoid not being involved with Women's Liberation when men have the audacity to confront you in those terms?

Women's Liberation, for Florence, means helping women to obtain the opportunity to achieve self-fulfillment, the fulfillment of their potential.

Women need to be able to develop their lives and the status of women neods to be changed. But in order for women to achieve self-fulfillment they need to be independent economically.

She feels at odds, however, with some of the activities within the movement; she dislikes the "young radicals who turn poople of $f^{\prime \prime}$ and feels their behavior is detrimental to the goals of Women's Liberation. In terms of her personal Iife she says she feels more independent, that she no longer feels her husband's permission is required to do things, she feels she is capable of living without a man and thet her husband and family are no longer primary in her life. She says she is also much more outspoken now, and she is anxious to get othar women interested in participating in the movement. However, she is not especially interested in explairo Ing her position to men. As for her situation at home, the divorce is pending.

Maybe it's possiole to have a relationship with a man outside of marriage, I'm not sure, but certainly not married.

On the job she receives less pay then men do for the same work though equally qualiried, and there too her participation in women's political activities is treated as a 
joke. She says, however, that her personal relationships with friends are reletively the same, she forms lasting friendships and has always valued the friendship of women and they reme in unchanged.

Florence says the characteristics she finds desirablo in men and women are: open-mindeness, intelligence, wit, and a sense of humor, all of which describe her aswoll. In addition, she is charming, animated, self-assured, and very gracious, and she is typical of the women who participated in this study and who are represented in these sample portrajts. 
FOOTNOTES

CHAPTER IV

IThese categories are derlved from how large numbers of participants in the Women's Liberation Movement view their participation, and they are defined accoraing to the particular ideology the participant subscribes to. However, some of the analysts of Women's Liberation political structure have different categories or greater numbers of them. Shulamith Firestone, in The Dialectic of Sex, (New York: Bantam Books, 1971), presents tirree typos: conservative feminists, politicos, and radical feminists. Her distinctions are somewhat different from mine, but cover the same general frame of reference. Because of the nature of my a ample and because it provides a more definitive description I prefer to model my categories after Juliet Mitchell's, which she details in Woman's Estate, (New York: Pantheon Books, 1971), pp. 94-95. My categories are more a contrasting of "conservatives" with "radicals" in the sense that the conservatives are not especially politically conscious and the radicals are inclined to bo political activists in some form.

$2_{A} 11$ of the names used in the rollowing portralts are fictitious to protect the informant's identity. 
CHAPTER V

DATA ANAIYSIS

In ordor to determine if Goodenough's model of Identity change correspends to the experiences of the informants in this study it is necessary to analyze the women's reasons for participation in the movement, and the extent of their involvement to see if a desire for identity change occurred and how it was achieved. This also involves an examination of the changes which they say have taken place in their Iives in order to determine if Goodenough's criteria for identity change are applicable in the areas of self-apprain sal and re-evaluation; and, to determine if there have been changes in their categories of perception, in their criteria for evaluating what is perceived, and in their habits of lising these categories and criteria. Such an analysis elicits the kinds of Iearning situations and confrontetions which load to identity change experiences.

In edation, the informants' levels of participation are considered in order to esteblish their segree of personal involvement and emotional commitment to making an ideritity change, This also permits an interpretation of their anticipation of a new status, their adoption of now roles, and the degree of their dis-association with their former 
identity.

Further, an enalysis of informants' discussions concerning their participation, and their conception of the problems involved, as well as the kinds of solutions they envision to deal with these problems, permits an ovaluation of their understanding of what they want changed, and how they are going about mastering now roles. Moreover, a consideration of the acceptance or refection of others is necessary in order to evaluate the possible success or filure of identity change as a result of participation in the Women's Liberation Movement.

In addition to the above, the age, income level, marital status, religious and political preferences of the informants, as woll as the ir occupation and occupational experiences, (that is, the statistical characterlistics of the informant group), are compared to determine if simflarities exist which might have significantly influenced their participation in the movement.

All of these factors are examined in light of the categories selocted from the fleld data for analysis. Following is the date analyais by category.

\section{REASONS FOR PARTICIPATION}

Reasons for participation in the Women's Movement vary depending upon the individual's life circumatances. The reasons which emerged from this study included: in. 
tellectual curiosity, some personal emotional experience which was identified with the ideas of the movement, related political activities, exposure through a friend to Ideas or activities of the movement, accidental exposure, and in some cases a combination of these factors.

Only two of the twenty-six women became involved strictly out of intellectual curiosity, although this subsequentiy chenged to emotional identification once they were involved. In both cases these women had pilor exposure to radical political activity and both felt a sense of strong commit. ment to making social changes. Eight of the women had some personal experionce which caused them to relate it on thoir own to idess of the Women's Movement, fourteon became involved through the introduction of a friend, either to the ideas or to participation in rap groups, and two became involved as a consequence of taking a Women's Studies course. Exposure to some of the values and goals of the movement resulted in an emotional identification with the movement on the part of the women in this study. For the most part this identification was the consequence of felt frus: tration or discomfort with their new swareness of the traditional role expectations for women. However, the degree of the emotional identification depended upon the individual woman and the quality of her past experiences. For example, all but one of the women expressed the fact that they had experienced difficult or frustrating personal experiences 
with men. And, 811 of the women folt the problem of having to assume major responsibility for making their relationships with men lasting and meaningful. The differences in these experiences and felt responsibilities influence the individual's omotional identification in participation in the movement.

One woman said she did not view her relationship with her husband as resulting in frustration (particularly as the relationship related to sex roles), nor did she feel obliged to assume more than her share of the responsjbility for making their relstionship effective. It is interesting, however, that in this particular case the informant was marriod to a man whose mother had been a radical feminist from an oarlier generation; moreover, the informant verbally acknowledged her soemingly unique situation and had an apparently clear understanding of the situations of other women whose experiences weren't her own. But, for the most part, women's personal problems with men were a primary factor for participating in the movement; that is to say, thoir difficulty in ostablishing and/or maintaining satisfactory relations with men resulted in thoir identifying with the Women's Hovement and becoming involved. Specifically, fifteon women in the informant group became involved as a direct result of Identifying their personal problems with men to the ideas of the movoment.

Whore such an identification was not a primary factor 
In participation, it became a socondary factor for all of the women as their oontinued identification with the movemont was related indirectly to past experiences with men. But, a secondary factor it involved identification as a consequence of more general relationships with mon. Such experiences concerned the various forms of social role interacting betwoen malos and females, a new understanding about the kinds of restrtctions placed on women in emplopment situations and on their social behavior in general, a growing knowlodge of the general social behavior and attitudes males have been taught to project regarding women, and the implications of these attitudes, and an awareness (for some) bout the economtc restrictions placed on women and their forced dependency on men for economic support, (that is, in terms of the general over-all position of women).

For eight of the women a primary factor for initial participation had to do with related political activities, eithor anti-war demonstrations and campaigning, civil right. activities, sociallst politics, or some related type of activity. Participation in these activities helped to introduce and make them favorable to the Women's Movement. For six of the women, participation could bo classified a accidsntal; that is, they were accidentally exposed to the ideas of the movement either by taking a course (as was the experionce of two women) or by attending a rap group sossion at the finvitution of a friend. The majority of the 
women, however, becamo involvod intentionslly as a conseauence of identifying in some way with the ideas of the movement.

Developing a sense of identification with the movement, for women who became actively involved on their own, took place over a period of time prior to active engagement and in these circumstances the influenco of ramily, friends, personal experiences, and related political activities were all significant influencing factors in developing their interest in the Women's Movement and bocoming actively involved. In addition, reasons for participating were not mutually exclusive; that is, in some cases the primary factors for women's participation had to do with both related political activity and awareness about their difficulties with men; or, their personal experiences and their accidental exposure to the ideas of the movement connected and resulted in their participation, and so on.

Thus, reasons for participation have to do with the oarlier iffe circumstances of the informants, as well as the specific situations relating to their immediate involvement.

\section{SPECIFIC ASPECTS OF CHANGE}

Initial participation for all of the informants produced self-reappraisal and re-evaluation of themgelves, their values, and their past experiences. Without exception, 
participation resulted in evaluative experiences, that is, a revising of their estimation of themselves.

Basic to this evaluative reappraisal, the informants experienced, was a change in their attitudes towards men, an awareness of having learned to defer to men in personal interactions; and, this new awareness result ed in a feeling of resentment, for some a feeling of anger, because personal interaction with men seemed to require deforence behaviors on their part, and feelings of frustration with themselves for having deferred in the first place. All of the women acknowledged this situation as an aspect of their personal lives, either presently or at some time in the past. In addition, the women experienced a re-evaluation of what the had learned to be as women, what they had learned regarding types of dress considered appropriate for women, specific behaviors that are usually defined as "feminine," forms of language that are considered appropriate for women, and the social norm which implies that the first and most appropriate career for a woman is to bo marriod and heve chlldren. Many of the women made consclous changes in dress,. mannerisms, personal actions, and language usage as a result of particlpation. Such changes included: wearing clothing that would ordinarily be considered "unfeminine" or less "feminine," giving up certain personal habits such as shaving logs or wearing make-up, eliminating actions construed as "female-role playing," (0.g., firtatious bohaviori, 
being more casuel in terms of posture (standing or sitting), performing definite anti-social actions such as making obscene gestures in public, and incorporating more "masculino" language forms into their normal usage, in particular obscenities. Those women who did not make specific external bohavioral changes did indicate that the $y$ had made internal ones; that 1s, they had experienced an emotienal decrease in their sense of Identification with the way they looked or acted; but, for younger women especially, conscious personal style changes were a drect result of participation. (Out of olghteen informants who stated that such changes in external behavior had occurred, ten of them were in the under25 group.)

All but one of the women sald there had been a corresponding change in their attitudes towards other women as a result of involvement in the movement. They indicated that they had developed a helghtened consciousness about women, an increase in receptivity to women, and identification with otluer women as havine the same kinds of problems. This included the oxperiences of the two women who stated they. had homosexual preferences. The exception to this situation said she had aiways felt this way about women, that she had long established relationships with women and ldentified keenly with their problems.

In addition to reporting changed attitudes and perceptions about men and other women, all of the informants 
said that participation had resulted in a change in their attitudes about themselves. Women in the under-25 group experienced "some" positive improvement in their attitudes about themselves, women in the middle group said their attitudes about themselves wore "markedly" botter, and the oldest age group said their self-conceptualization had "dramatically" improved. The degree of emotional response expressed in regards to improved self-conceptualization was also related to the individual's level of participation in the movement; that is, the greater their level of participation the stronger their sense of self-improvement.

Both evaluative and cognitive reappraisal aro aspects of the identity change process, according to Goodenough's model. However, not all of the women seem to have experienced "cognitive" reappraisal; that is, not all have seen themsolves since participation as different persons with different inds of personal characteristics significantly different from ones they formerly thought they had. This aspect of identity change is somewhat difficult to elicit in an interview unloss the individual is posttively aware. of having undergone specific identity changes and can verbalize about then (or unless in the interview they are asked specific questions leading them to this lind of conclusion, which I tried to avoid). Most of the informants recognized some evaluative changes, for those who did not, that is, those who said they were still the 3 ame person as 
before, expressed attitude changes were indicative of their having undergone evaluative experiences. Drawing the line between "cognitive" reappraisal and "evaluative" reappraisal requires that the interviewer make inferences from the same set of experiences and most of the informants indicated that they continued to see themselves as essentially the same as before they participated in movement activities. Only four of the informents discussed the fact that they felt they had become different kinds of persons since becoming involved. All of the informants, however, felt that exposure to the ideas of Women's Liberation had produced definite perceptual change "from which you couldn't retreat," (a coment frequently made during the course of the interviews).

\section{DEGREE OF PERSONAL INVOLVEMENT}

In applying the categorioal distinctions made earlier between "Liberationists" and "Radical Feminists" (see Chapter IV, p. 81), eight of the women in the informant group can be classified as "Radical Feminists" (the same oight who had prior experience in radical politics), the remainder fall. into the "Liberationist" category. This categorization is a useful way of measuring levels of participation, for without exception all of the eight, classified as radical ferinists, are the most actively involved both in terms of emotional commitiont and in terms of actual levels of participatior. This categorization, however, does not adequately 
Indicate individual levels of emotional commitment or actual particlpation in activities, but it does indicate attitudes concerning emotional involvement and participation. Regardless of the specific views each woman holds concerning the content of Women's Iiboration ( or what they think this content should be), all feel a sense of personal commitment to various ideas and goals of the movement.

Expression of this emotional commitment varies, and can be examined according to the forms individual partic1pation takes. Five of the women in the liberationist group are actively involved in organizing other women, into rap groups or political action activities. The remaining thirteen (of the $s$ ame group) are involved in self-education through reading, participation in rap groups or Women's Studies courses (or both), and some are involved in relatod political activities (e.g., Women's Health Clinic, or volunteer work for organizations related to the Women's Liberation Movement). For these women in the latter group, organizing other women to becomo involved is limited to talking to them about the movement (when it is possible to do so). The activities of the oight radical feminists includes both active organizing in a number of groups and continued self-education through whatever means \&vallable.

Emoticnal commitment varies with paticipation level. For those actively invelved, the sense of comitment is very high, for those just getting involved, the comritment 
is not as strong. 0lder women in the group display a stronger sense of emotional commitment even if their actual participation is low. Five of the women (in the Liberationist group of thirteen previously discussed) indicate a much greater level of emotional commitment than their participation indicates. They too, state a strong sense of identification with the movement and would like to do some active organizing, but do not, either because of shyness, lack of opportunity, or lack of ava1lable time. Only eight of the women indicated what could be classified as a nodorate" emotional comitment and all of these saw their participation in the movement as being a personal involvement rather than a social involvement. (That is, they were concerned about making changes in their personal lives and viewed their activity as a means to this end rather than as a means to social change in general.)

For most of the women, participation has resulted in some form of struggle over their emotional involvement and In some cases a feeling of strong resistance towards some of the Ideas and goals of Women's Liberation. For example, two of the women do not agree with the movement's advocacy of abortion in any form. For others the emotional struggle has to do with kinds and forms of social change, ideas about personal bohavioral styles (e.g., the psychological import of wearing make-up or being especially "feminine"), and genoral emotionel responses to atterpte of changing 
personal attitudes and values to conform with their new perceptions about the character of thoir situation of being female. For example, two of the "radical" women in the study said they had no emotional difficulty relating to most of the ideas and goals of the movement, including the need for revolution in whatever form, however, they professed some emotional struggle with the idea of not wearing make-up, al though the s said they understood the ideological reasons for not doing so. On the other hand, all those who felt no conflict in this same area expressed a great deal. of conservatism about political change. Both of these situations correlated with the kinds of bohavior they manifested in the past. If the individual had wom make-up before (usually over a long period of time) she resisted the 1dea of not doing so now, or if the woman had been conservative politically before, she remained conservative. Common emotions which ran through all of the intorviews were anger and frustration, and the degree of felt anger had to do with the kind ond quality of their past experiences, particularly with men. Women who had partic-. ularly difficult or unpleasant experiences in their personal involvoment with inen were ospecially angry. Only two of tho women indicated a sense of mild frustration and anger, and these were the samo women whose personal relations with men (especially their husbands) were the most stable, (however, both indicated a sense of frustration with 
men in general).

For the most part, the women who fit Goodenough's: model most exactiy are those most actively involved in organizational politics and thus they are the ones making the largest offort to change and the ones most emotionally committed.

IV. UNDERSTANDING OF CHANGES: PROBLEMS AND SOLUTIONS

The women's view of what they wanted changed was determined by the kinds of confrontations they had experienced and their degree of awareness of the values and goals of the movement. Their level of awareness in tum shaped the way in which they porcelved the problems in making changes and the kinds of solutions they perceived as necessary to produce change.

By and large, all of the women felt they could change themselves to be the kinds of persons they had learned to want to be as a result of participation in movement activities. That is, in order to incorporate the values and goels of the Women's Movement with which they identilled. they perceived they could change some of their former behavior or ideas and they saw this as something possible to do on an individual basis. As individuals, for examplo, they could refuse to play the role of a "flirtatious" woman or refuse to dress as a female "sex object." These were things theg could do through personal action. Not being 
obsequious or deferring to men in interpersonal relationships were again things they could do as individuals through individual action. It was, however, on the level of political awareness and polftical action that the women began to display marked differences in their understanding of what it was they wanted changed and how they perceived differences in tho problems and solutions to change.

All of the women perceived the major problem in achievement of identity change as being either difficult or imposible because of the fact that what they desired in the way of change is not socially acceptable at the present time. Some of the nomen verbalized about the fact that under present social conditions there were no "guide I1 nes" to adopt as models and that the traditional models are unsatisfactory alternatives. The study group can be divided on this aspect of identity change into two kinds of groups, those who see the problem as a purely personal one capablo of boing soived by individuals and those who see it as a social phenomenon requiring a complete over-haml of the existing social conditions. Here too, the kinds of previous associations and confrontation experiences the have had detormine their perception of the nature of the problom. Although the problem is viewed by some as a personal problom capable of solution through individual action, these women agree in foeling it is a problem that all women have and therefore one all women must deal. with even though on an 
individual level. In the study almost half of the informants (twelve) perceived the problem from this perspective. Everyone in the study conceived the existing status of women as a problem for ail women, but only helf of the group percelve it as a social and political problem, requiring active social and political solutions. Thoir solutions, however, vary.

The extent of personal involvement in movement activities reflect tine way individual informants viow the problem of change, and also reflect their degree of awareness about the ideas and goals of the Women's Movement in general. Those not actively involved tend to see solutions as individual ones, these more actively involved seo it as a social problem requiring social solutions. And hers again the level of participation and the degree of understanding about what they want changed is a roflection of the individual's reasons for particlpating, the kinds of confrontations to the ideas of the movement they have experienced, and the variety and forms of their previous experiences.

The women who became initially involved out of in- . tellectual curiosity, had prior radical political exposure, and identifiod on an intense amotional level to the content of the moverent, and they viowed problems to change as essentially social problems requiring extensive political reform. On the other hand, women who had littlo or no exposure to radical politics, and were introduced to the ldeas of the 
movement through a friend, relate to it less intensely mo. tionally, and see the problems to change on a personal level. Four of the women could be classified as "Intermediate" between the two groups. They had some exposure to radical political activity, and sora difficult experiences with mon, and their participation in the movement produced a strong sense of identification with the need for positive political action, although not necessarily "revolution." In all of these cases their understanding of the problem and solutions is verballzed as "hazy," "confused," or "still trying to work it out." Informants in the lattor two groups (individ. ual versus social action roform) are positive in their responses to questions about understanding what they want changed, and how they perceive problems and solutions.

Those who see the problems in terms of individual sol. utions felt that solutions lie in the areas of developing self-awareness, and educating other women to the need for change. Those who see the problems as requiring general social change through political action resort to a variety of methods for achleving it. All of these women were in-. rolved in pereuading other women of the need for changs, by talking to them, by organizing them into rap groups, or by becoming involved in political action activitios. Goodenough points out that another solution to the problem of achieving ldentity change is to seok memborship in a now community whore different systens of soelal catogorios 
exist (see Chapter II, p. 50). Six of the women adopted this idea as a partial solution for they have taken up residence with other women who share their views.

All out revolution is something "wished" for by the women in tho "radical" group. Thoy talk about this as being the only means of effecting lasting change, and they see this solution as involving a complete change in tho existing status of women, an ond to all forms of social, political, or economic discrimination against not only women, but other minority group nembers as well; they also seo it as an end to the capitalist economic system and war "as an instrument of imperialist control," and the establishrent of the socialist society in which "the potential of every individual" has the possibility of being realized. In addition, they admit this as a utopian fantasy and quite unlikely of fulfillment; however, they see the solution to change, in the meantime, as requiring an extensive effort on thy part of women to bring about better conditions for themselves and this is rerlected In the forms their comitinent obligations take.

$$
\begin{aligned}
& \text { V. FROFESSED DEGREE OF UNDERSTANDING } \\
& \text { ABOUT THE CONTENT OF NEW ROLES }
\end{aligned}
$$

To analyze the women's degree of understanding about the content of theix new role it is nocessary to evaluate the types of pexsonel actions they say thej porform since becoming involved. the kinds anc sources of models they re- 
late to, and the degree of their understanding of the specIfic characteristics of the new identity.

The ten youngest informants in the study vero most actively involved in making personal style changes in dress and behavior; moreover, these were the womon who indicated the most concern about being percelved as "sex objects." This was not an expressed concern on the part of the older women; their expressed concern had to do with the psychologIcal deference of women to men, and they discussed their own attitudes about female/malo deference patterns and role playing to a considerable extent. The older women indicated they felt this was a basic cause of the inferior status of women, and they discussed thelr ow problems in trying to cope with this aspect of their behavior. Two of the women In this group indicated they felt that a lack of deference to men on their part was a major resson for their experiencing continual problems with men in interpersonal relations. Several of the other women in this same group (eight) sald they had come to realize this problem of having to defer to mon was a major source of conflict between themselves and. men. The remainder simply acknowledgod it as being the "situation romen find thomsolves in."

The women who were dealing with identity change in texms of eliminating the "sex object" role, they felt they might have boen playing before, did not relate as strongly to the idea that deference to males was a part of their be- 
havior, in fact, most did not montion it at all. There was, however, a strong sense of "individualism" among these informants and all of these women were in the under-25 age group; therefore, age might have been a factor in their perceiving their situations as they did.

The older women informants (the over-25 group and one age 24) expressed a more positive sense of security about their identity and were most concerned at this point with the nature of their behavior. For the most part they did not express any discomfort with themselves, simply with the ldea that they had learned to defer as part of fomale role playing, and they expressed a concern about the necessity for women to understand the nature of this particuler aspect of their behavior and try to eliminate it.

In relation to this aspect of role playing, the informants generally verbalized about the need for women to stop seoking "male approval" for their behavior. This idea was expressly stated by at least half of the group and those who developed it in interview sessions were, again, those women who had the greatest exposure to the ideas of the movement. The women with the least amount of exposure and 1dentification expressed tho least amount of understanding about what it was they wore trying to achieve, or what it was they felt women should be. One voman expressly stated that it was easier to bo "a new kind of person whon there was a model of the person you warted to be." She expleined that she had a 
friend who had been partially responsible for hor involvement and who served as hor "model." She stated that this was a model of someone who "knew what they were as an individual" and displayed a "positive sense about Women's Liberation." In her caso, the friend served as a role model. Half of the informants expressed the noed for women to toke self-defense courses and four of the younger informants were doing so. They expressed this need as being something women should be capable of in order to copo with the problems of being molested and/or raped, very old concerns of women.

The degree of understanding about the specific characteristics of the new identity varied. As was noted earlier, only four of the informants expressly stated they were conscious of being "different people" since becoming involved. They said this meant that "their whole perception of themselves" had been revised. All of the other women hed undergone evaluative reappraisals which had produced modifications in their behavior and/or perceptions of themselves and various aspects of thoir lives. How they per-. ceived these changes apecifically depended upon the extent of their active involvement in Women's Liboration activities. The young women who were still dealing with it on a porsonal lovel did not verbalize about perceiving themselves difforently or having adopted new roles; however, their attempts at change give indication that they vere, in fact, adopting 
new roles and expressing it through dress modifications or behavioral changes.

All of the women indicated that particlpation had resulted in changing some espect of their lives which in turn had changed some sspect of themselves.

VI. PERCEPTION OF THE ACCEPTANCE OF OTHERS.

The response on the part of family, friends, and acquaintances to the women's involvement in Women's Liberation was, on the whole, negative.

Participation resulted in the failure of at least two marriages, (one woman's husband divorced her as a direct result of ber participation, a second was planning divorce as a consequence of her involvement). Two of the women actively adopted homoserual behavior (which they had suporessed before), and this in turn ostracized them severly with former friends and family. (One had problems with her immediate family, the other woman's family accepted her homosexuality, but her friends rejected her as a consequence.) Eight of the women discussed the strongly hostile resctions they received to their participation on the part of their husbands or male friends. The oldest woman in the study group said her husband would not "allow" her to discuss Women's Liberation in his presence. Another eight of the young women sald their families responded with very nega tive attitudes; one woinan indicated her parents viewed f.t 
as "a phase" she was going through (see portrait number two in Chapter IV). A number of the women experienced the loss of personal friends as a direct consequence of participation, and all of the women experienced hostile reactions from people on job eituations, when speaking in public gatherings, or from casual acquaintances. One woman was fired from a job as a result of publicly acknowledging her membership in Women's Liberation.

Although the women reported they were often subjected to hostile reactions regarding their participation, from both men and women, they stated that the overwhelmingly hostile responses came predominantly from men. (However, this has not always been the experience of women in the movement at $18 \mathrm{rge}$.)

One of the immediate consequences of being received with hostility from others was a fouling of the need to defend one's self and one's particlpation. One woman stated she became even more involved as a consequence of the ridicule she recelved from friends. The only informant in the study who said she did not defend her position but. simply remajned "silent" in the face of opposition did aay, however, that she wished sho had the "herve to speak up," and was "ver'y happy" whon other women did.

In general, the kind and qualiț of response to the women's particlpation correspords with a survey made in the initial phases of this research and will bo discussed in the 
concluding chapter.

\section{PERCEPTION OF SELF SINCE. PARTICIPATION}

How the women perceive themselves since becoming particlpants was uniformly expressed as "more self-confident." The adjectives the women used to describe themselves since becoming involved included:

-..more aggressive, self-confident, more outspoken, strong, more independert, more sure of themseives, more positive, more determined, more aware of their capabilities, more achievemont orlentod.

Again, how the informants perceived thomselves corresponded with the extent of their involvement in various activities and their opportunities for performing in their new roles. Those who had limited opportunity and were only moderately involved viewed themselves as improved about their sense of self, but did not acknowledge any difference beyond this. Those who were actively involved were more highly conscious of a stronger, more positive sense of self and could discuss it in specific terms; moreover, those most actively involved acknowledged a feeling of continual growth and change, a marked change in their perceptions and attitudes and a clear undorstanding of the fact that this had altered their personalitios.

All of the women felt a desire to share their experlences with others. Most of the young women (nine out of ten in the under-25 group) were anxious to share their per- 
ceptions with men as well as women. Only three of the remaining sixteen women were interested in sharing their experiences with men as well as women. The contrasting views to this situation were expressed as:

1) mon need to understand too because it is a problem for them as well as for women; 2) men, if they want to be "liberated," had better educate themselves.

Here too, the responses seem to be affected by the age of the women and the extent of her involvement.

A number of other factors show up in the study; all of the eight "radical" women are non-religious and "left" pollt1cally, all of the women in the "very conservative" segment oither profess a religious belief or are "unsure" about it; and, in addition, they are relatively conservative in their political preferences, These two considerations, religion and political preferences, seem to be more of an influencing factor on the level of particlpation and the degree of change that follows than either income or sducation level, for which no significant correspondences appear.

Following are the conclusions drawn from the application of the theoretical framework to the research data and a brief discussion of the Wonien's Movement as a whole. 


\section{CHAPTER VI}

\section{APPIICATION OF THEORETICAL FRAMEWORK TO DATA}

Aro the activities of movement participants consonant with the theoretical modol of identity change process presented in Chapter II?

According to the theoretical model:

the process of identity change for the individual is a consequence of specific kinds of realizations which are fostered by a series of definable stages (see Chapter II, p. 39).

Theas stages or necessary conditions for identity change consist of: 1) a desire for change on the part of the individual, 2) a commitment to making a change, and 3) an understanding of what needs to be changed. And, according to the theoretical model, in addition to these essential conditions, 4) acceptance on the part of others is also necessary if lasting change is to be realized.

By applying the conditions for identity change in the theoretical model to the participation experiences of the informants it is possible to determine how participation in the Women's Liberation Movement effects identity change in individual members. 


\section{INFORMANTS' DESIRE FOR IDENTITY CHANGE}

In the theoretical model the identity change process initially involves a desire for Identity change which is achieved by self-reappraisal as a result of having new experiences and making an effort at reappraisal as a consequence. Self-reappraisal and learning now criteria for selfreappraisal is produced through varinus methods of confrontations: 1) as a result of defense of self, 2) being subjected to structured experiences, and/or 3) through demonstrations. Such confrontation experiences result in changes in the individual's porceptual categories and in eriteria for ovaluating perceptions. Further, such changes in an indiviaual's habits of using these categories and criteria produce adaitional reappraisal experiences (see Chapter II, p. 42).

Analyeis of the informants' reasons for participation and the specific aspects of thoir lives which changed as a direct result of their participation shows that the desire for identity change is present in all of the informants. However, the intensity of the desire varies with the extent of reappreisal which has taken plece, for the effort made at reappraisel dopends upon the kind of confrontation experiences the informant has. These in tum are shaped by their previous personal experiences and tho kinds of experiences they permit themselves to become involved in as a consequence of their prior experiences. (For exarale, the individ- 
ual whose prior experiences do not include activity in radfeal politics does not got immodiately involved in radical political activities upon becoming a participent in the movement. Instead, participation level remains closely tied to activities performed prior to involvement.)

All of the informants experienced one or more of the various confrontation situations that led to self-appraisal; that is, confrontations were produced as a consequence of having to defend one's self, or as a result of being subjected to structured learning experiences through rap group exposure or a Women's Studies course, or by being helped to achieve a desire for identity change as a result of demonstrations on the part of others.

Whatever the individual reasons for participation were, that is, whether the involvement was out of intellectual curiosity, accidental exposure, or the introduction of a friend, it prodiced an emotional identification with the Women's Movement for all of the informants. The lovel of this emotional identification was dependent upon the indiv1dual's prior life experiences and the specific types of . confrontation situations they experienced in their participation in tile movement. This in turn had an impact on the quality of reappraieal efforts and the subsequent level of individurl identity change.

The dasire for change is immediately reflectod in the spocific aspects of change which informants say have taken 
place in thoir lives. AIl of the informents underwent evaluative changes which produced changes in their categories of percoption and their criteria for evaluating these categor1es. For example, an inftial category which underwent change was their usual perception of the traditional social role of being femalo, that is, all of the informants acknowledged a change in their perception of womer in general and what it moant to them to be women; furthor, all of the informants expressed a change in their attitudes towards men and the criteria they had previousig used to perceive how they should behave in regards to men.

The desire for identity change was reflected not only in perceptual changes on the part of inaividual informants, but also in the behavioral changes which resulted. Changes in perception of what constituted the "proper" or traditional social role of being female (as each informant conceptualized this) produced changes in external appoarance and actions, that is, changes in dress, mannerisms and language usage, the "givingup" of actions conceived of as being "typical femalo role playing."

For somo informants the self-appraisal process was demonstrated crily through atitude changes, whereas others adopted physical changes. Thus, the dosire for identity change on the part of the informants was expressed both in implicit and explicit terms.

Tho extont of effort mado at perceptual change affected 
the kind of reappraisal which resulted. Fxtensive offort at evaluative changes were more likely to result in cognitive reappraisal (see Chapter II, p.42) as well as evaluative reappraisal as the research data indicates (seo Chapter V, p. 124).

Part of the desire for identity change has to do with the effects of confrontation, that is, confrontation with the self frequently results in resistance because the porceptual categories undergolng change are usually those which the Individual foels expecially concerned about emotionally. Informants in the study expressed their concern about the apprehension the often experienced during thoir initial involvement as a consequence of such felt resistance, and they noted that continued involvement helped to ease the difficulty of this experience and enable them to better understand themselves and what they wanted changed. Thus, attempts to deal with difficult or uncomfortable confrontation experionces facilitated increased involvement and the desire for change.

Many informants also expressed the fact that intensive personal involvoment with other movement women helped to increase their understanding, and the rap group interaction technlques which involvo methods used in psjchological counseling were especially offective in stimulating change and overcoming Indivicual resistanco. Moreover, rap group confrontations produced rurther individual reappraisal along 
the lines of values and goals of the Women's Liberation Movement and enebled the individual to better understand why they had inftially Identified with Women's Liberation.

\section{INFORMANTS COMMITMENT TO CHANGE}

The second necessary condition for identity change in the theoretical model involves a commitment to making change which can be: 1) through the performance of some action that anticipates the new status, 2) through performance In the new role, and/or 3) engaging in some physical and/or psychological commitment to the new identity.

Evaluating informants' commitment to change involves analyzing the degree of their personal involvement in terms of felt emotional commitment and their actual level of particlpation in various movement activitios. It also includos an analysis of the kinds of consclous changes they say the have made since becoming involved. (Desire for change and commitment to change are arbitrary distinctions made for analytical purposes and the actual bohavior of the informants overlaps these arbitrary categorical distinctions, as In the case of stated changes which have occurred since participation. It 1s possiblo, howevor, to analjze the same set of data from these different categorical perspectives.) Demonstrations of a commitment to change requiros that there be some important modification in one's former personal style, that is, a demonstration of ono's comnitment to 
making a change involves comiting one's self to some type of obligation that makes retreat from change difficult. In the case of informants' participation in the movement modifications were made in two general areas; one, in physical changes in dress and mannerlsms, especially on the part of younger informants anxious not to present themselves as "sex objects;" and two, in attitude changes having to do with previously learned patterns of deference to males (and people in positions of authority); this latter was particularly characteristic of the older informants.

All informants Indicated they had made an enotional commitment to the Women's Movement, but the majority also comitted themselves to some form of activity which involved. the relinquishing of some former aspect of themselves. These comitments, especially for the younger informants, often took the form of rude or anti-social behaviors, radical changes in aress, and for four of the informants, courses in self-defense. For the older informants comitment involved rofusal to role-play with men, especially in interpersonal situations. Howovor, this latter situation varied to a markod degree depending upon the informant. For some this espect of comaltment to change produced what might possibly be classified as schizophrenic bohavion, that is, for some informants a change resulted in thoir attitudes about how they should relate to males and how women were usually expected to relate, and this change was further oxpressed both intel- 
lectually and emotionally, however, some of the informants could not modify their actual behaviors whon interacting with their husbands or male companions for fear of disrupting these relationships and the informants indicated their emotional concern about this as producing a "frustrating situation." (In some cases whore modification of such bohavior actually occurred the relationship was disrupted.)

Commitment to change, in informants who could not bring themselves to modify categories of behavior they oxpressed as necessary of modification, was usually relatively low.

The actual participation level of informants was usually an accurate indicator of the level of their omotional commitment to making a change, although there were a $f \in w$ exceptions.

Commitment to making a change included the conscious expression of informants' talking to other women about Women's Liberation and their desire to get other women involved.

The ovar-all expression of commitrnent to change ranged from "Low" to "very high" according to the incividual's level of sctual perticipation and their understanding of what they wantod changed. 
III. INFORMA N'S UNDERSTANDING OF WHAT NEEDB TO BE CHANGED

In order to facilitate successful identity change the individual must also understand what noeds to be changed, and according to the theoretical model, this third necessary condition for identity change involves: 1) possession of knowledge about the new role, and 2) a sense of certainty about the content of the role. Understanding what neads to be changed further requires that the individual making the change recognize the problems of achleving change, and the solutions to problems of achievement. Fallure to identify the problems or the social restrictions placed on change will prohiblt succossful identity change.

According to tho research data all of the informants expressed some knowledge about what they conceived their new role to be and, in general, they felt a strong sense of cortainty about their conceptualization of this role. Moreover, the informants 211 recognized that there existed various kinds of probiems in achieving this new role, however, the perceptions of exactly what constituted these problems varled with the informants level of involvement and prior exporiences.

Problems to acheivement could be classified into two categories: one, personal or individual problems, and two, collective or social problems. Further, the solutions the informants envisioned in eliminating the problems fis struc- 
tured by thair percoption of the problems.

All of the informants percelved social blocks to the successful achievement of identity change, that is, they all agreed that the major problem in change lay in the fact that the changes they desire are not considered socially acceptable, at least not currently. (They could all verbalize about the idea of "equal pay for equal work" being generally accepted as a desirable goal for women too, but the idea of women's being "the complete equal to men in everything" was not generally acceptable socially.)

In addition, all of the informants felt that it is posstble to produce some kinds of changes on on individuel level and that it is desirablo to do so. Howerer, beyond immediate perzonal stjle changes not all of the informants have clearly in mind the kinds of oter-all changes that would produce lasting results. Then too, informants differed on their perception of the kinds of individual changes they concelved of as desirable to make. Not all agreeds for example, that dramatic changes of dress or discarding makeup use were necessary or effective tactics, and not all agreed that it was "pointless to talk to men" or oven desirable not to do so. However, all dia agree that the problem involves changing the conceptualizations of men as well as of women.

Those who adbered to the idea that solutions were possible simply through developing individual awareness and 
getting individuals to chango held markodly different polltical perspectives from those who adhered to the ldea that permanent solutions were only possible through collective action an social institutional change.

The solutions adopted followed the lines of how the problems of achievement vore conceptialized, but all of the informants believed that one solution to the problems (whether viowed as personal or social) la y in peryuading others to change their valuation of the present identity of women and to convince women, especially, of the need to change. All of the informants agreed that the existing status of women in general could be changed if others could be persuaded to accord it the same privileges and esteem that are generally accorded to men in this society.

However, different informants had different perceptions of the existing privileges and esteem accorded to men. Some recognized, for example, that it is primarily white men who have the highest social status, thus acknowledging social caste distinctions, whilo other informants dia not make such a conscious distinction. Further, those who recognized social caste digtinctions also made distinctions on economic and social levels, that is, they folt "privilege" itself, both oconomic and social must be accorded equally throughout the social structure, and auch perceptions of the problem lead to a conception of the problems of achievement as being essentiaily collective not personal, and requiring over-all 
social reform. (Some of those who viewed the problem as a collective problem were also concerned about the crosscultursl implications of sex-role stereotyping and its effects on women, and as a consequence their view of the extent of the problem and the difficulty of solution was quite different from those informants who focused on only their own social milieu.)

Although complete social reform was viewed as the most desirable (and in some cases the only) solution to problems of achievement of ldentity change, it was not seriously viewed as a solution in either the immediate or distant future by those who held this view, that is, a revolution was not expected to happen as a realization of the problem. For the most part this solution was conceived of as "something to be wished for" but "unlikely." For those who viewed the oblem as a collective one the most immediate solution was recogntzed as an organized mass movement of women engaged in traditional forms of political action. The adoption of collective movements as a solution was a consequence of the fact that some informants perceived no oxisting opportunitios to fulfilment in the existing social categories and they did not foel they could oscape into different social environments although they did adopt modifications of this solution, thet is, many informents found some solution to the problem of achiering jedentity change by seeking membership in a congental sub-group or "community." 
Six of the informants were living in "communities" with other women who shered their attitudes and beliefs about Women's Iiberation. The "community" in these cases was simply participation in a common household grouping. Other women in the informant group found membership in rap groups or Women's Movement related activities and this helped to achieve similar onds as taking up membership in a kind of community where everyone shared the same system of social categories. Not all of the informants felt the need to soek membership in like-minded groups of people, but more of the informantis would have liked to than actually did, and, further, they envisioned this as a reasonable method of improving their understanding of what they wanted to be changed. The more politically active and aware the informant the greater the desire for membership in such situations.

Those informants who acknowledged strong preferences for collective action and perceived change as being essentially social change held two different views about solutions. There were those who continued to value traditional goals for themselves and felt that the solutiona were. eimply a matter of removing the spparent obstacles to achievement. That is, inforinants who felt women's status could be made equal to men's if women were given equal pay and equal job opportunfties sav the problems to solution as consis: ting of making such opportunities available to women.

The second view perceived the traditional methods of 
self-realization as invalid and felt the solution to the problem of achieving self-realization had to come about, ultimately, through a total revision of the social order.

Thus, the direction the movement should take meant social reform to some, and social revolution to others, depending upon bow they concelved the problem.

Those who held that a total revision of the social order was the only reasonable solution were also those whose comprehension of the ideas and values of the Women's Movement was most extensive, and whose political preferences could be classified as the most "radical." However, not all of these individuals seemod to have clearly in mind the specific models of what would result from total sociel reorganization.

Although all of the informants felt a strong sense of certainty about their participation and their understanding of their reasons for participation not all of them felt the same certainty about thoir understanding of problems to achievement and solutioris to such problems. Those informents who felt atrongly about ptoblems being personal ones, and those who felt strongly giout the problems being collective were lso positive about their senee of understanding. Those informants who were not sure about how they, should categorize the problems were also still working out their understanding of what specifically they wanted changed end how to achieve this. 
Thus, an understanding of the specific characteristics, duties and responsibjities of the new identity depended upon the form understanding of problems and solutions took.

\section{INFORMANTS' PARTICIPATION ACCEPTANCE}

The identity change process, to be completely successful, must have the acceptance and approval of others. In addition, the individ ual must have the opportunity of displeying the new ldentity and performing in the new role in order to develop skill in applying what they have learned and in order to complete the identity change.

If acceptance on the part of others to the informants desired identity change is crucial for the success of the lidentity change process, as the theoretical model indicates, then evidence from the research data would lead to the conclusion that identity change is not going to bo markedly successful.

All of the informants in the study gaid the $y$ had experienced a considerable amount of refcetion from others in regards to thelr participation in Women's Liberation. One informant stated that she adopted a "silent" position when confronted with negative responses. Another informant said she was not "allowed" to discuss the subject at home, her only opportunity for experimenting with the new rolo was linited to her rap group participation. Other informants indicated that they could not overtly engage in behavioral 
changes in their interpersonal relationships with men for fear of destroying the relationship, thus their opportunities for displaying the new identity and performing in the now role were limited to social circumstances outside of their home environments.

Only those informants who had modffied their living situations to conform to their new attitudas about their Identity as women can expect to achleve any degree of permanent identity change, if the suppositions in the theoretical model are correct. Moreover, those informants who are making the greatest effort at change, who are most actively involved in participation in Women's Movemont ectivitios and/or who bave modifled their living circunstances to accom. odate to their desired changes are the ones who have the groatest opportunity to achieve mastery in their new roles and thus are most likely to accomplish permanent identity change.

SUMMARIZATION OF CONCLUSIONS FROM THE STUDY

All of the informants have experienced new self-con: frontations, have boen subjected to new and in some cases, afficult inducements to change; all have modified et thor their physical andor psychological behaviors to accomodate to the desired chenges; all are involved to some degreo in sharing their identity change experiences with others; and al I have some understanding of what they went changed and 
how to achieve it. However, not all of the informants can exert the same degree of effort in promoting their individual involvement, and many are blocked from achleving effective identity change because of the negative or hostile reception of other's and the refusal on the part of relatives and friends to recognize the now identity.

The most effective changes occur in those informants who are most actively involved, those whose understanding about Women's Liberation, in general, is most extensive, and those whose political involvements are the most socially oriented.

In goneral, the exporiences and behavior of the informants confarms to what is already known about women's participation in the movement and public response to this participation. An early report about the general characteristics of Women's Liberation participants appeared in tho Nove/Dec. 1970 issue of Transaction magazine. I The findings Indicated a correspondane with the findings in this study also, in that women who becamo involved in Vomen's Movement activitios are generaliy from middie income groups, Caucaslan, with some collego education; they are not prodisposed to accopting the iraditional female role (which labeis women as "passivo, cmotiond, Irrational, dependent, and inferiox to men ${ }^{n}$ as the orily merns of self-fulilliment, but recognizes other alternativas than boing wives end mothers as options to bej-fulfilimant. In addition, they often oxper- 
Lence some form of allenating situation prior to involvement wich helps them to identify with the values of the movemerit; they sense the discrepancies between what they know thoy can do or would like to do and what social traditions tend to dictate they do.

Further, because the belief system of Women's Liberation views the source of problems in the social system the goals of Women's Libaration are oriented to changing the system the solution, and those individuals who view the problems as sociol/political problems achieve the strongest identification with Women's Liberation.

Finally, women who are predisposed to defying traditional values and being "non-conformist" are also more likely to adopt Women's Liberation as an altornative to selffulfillraent. Many of the informants in this study noted their earlier refection of religious, political, or social viows in somo form, and number adopted political views often construed as "deviant" or behaviors labeled as "antisocial."

Subsequent to my inftial research I administered a. general. survey questionairo (soo Chapter III, p.63) in an attempt to olicit information ebout espects of public response to the Women's Movement. The findings Indicated that out of some 160 responser, roughly $90 \%$ of the respondants porceived the goels of Women's Liberation as a destro for economic and/or social oquality in general, approximately 
77\% agreed that these wero rosonable goals, espocially

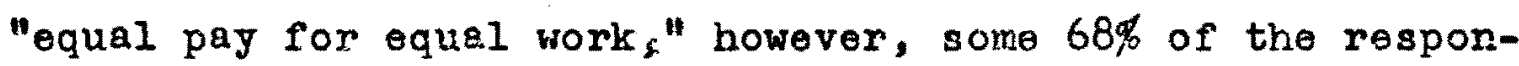
dents held negative or hostile personal reactions to the goals and activities of Women's Liberation. Out of 161 respondents only 12 were positive in their attitudes towards the movement as a whole. In general, epprovsl was granted as long as the goals were concerned with economic equality, but the majority held strongly unaccepting views if the activities of the movement participants involved other kinds of goals or if the actions of participantis wers viewed as "unconservative" or "Improper" in any way. Conly one of the 161 respondents in the interview said she was a particlpant in the Women's Movoment.)

The responses of questionaire informants was reflected in the attitudes of acceptance by others towards the interview group informants, and in general, intorview informants' experiences regarding the acceptance of others was viewed as reasonable only so long as the particlpation conformed to soclally acceptable levels of behavior and so long as the participants only sought "equal pay for equal work" or perhaps some modification of the social position of women especially as it rolated to fob opportunitios. (Theso rosponses from others are predictablo ones.) Beyond that participation was greated with bawilderment or hostility by family and friends for all but a small minority of the informants. All of tho informants reported that men espec- 
ially reacted with a sense oi fear and hostility and indicated they felt threatened by informants' participation.

The solution to obtaining acceptance on the part of others is percelved as persuasion and education, and when informants adopt such tactics oxtensively they furthor their own Involvement in the movement and facilftate the ochiovement of the 1dentity change process.

In order to determine if permarant identity change in the informants results as a consequence of participation in the Women's Liberation Movement a diachrontc followup is necessary. However, it is possible to draw a number of reliable inferences from this synchronic study. Ono is that the more extensive the active involvement in the Women's Movement the stronger the sense of identificstion and the greater the possibility for lasting change. Two, the evidence indicates that the closer the participants experiences conform to the theoretical model the more likely they are to exporience lasting identity change. Third, when particlpants lack opportunities for role experimenting or meet with pesigtance the loss likely they are to experience change or to. increase their involvement. Fourth, a key to partial change lies in indiviaual versus social ldentification of the problems, and change is more likely to occur when the participants view what neods to be changed as a social problem and adopt political action methods of solution. 
DISCUSSION OF THE IMPLICATIONS OF WOMEN'S LIBERATION

The attitudes and behaviors of the informants in this study correspond closely to the experiences of students taking Women's Studies courses. Young womon in courses are more concerned about being labeled "lesbian" or "Women"s Libbers," than are older women students. Older women stu. dents, in general, tend to be less concorned with appoarance and labeis, and more concerned with interpersonal relationships and social change. Those individuals who are strongly religious, regardless of age, have the most difficulty with the course material, especialiy if they adhere to some type of fundamentalist belief system. Those students who express strongly conformist attitudes do not relate woll to the course, wheroas those whose attitudes and experiences are similar (in general) to the informants' in this study identify strongly with the course and go on to take others of become involved in Women's Movement activitios. Women's studies courses also have intoresting impli: cations in teris of the Women's Movement as a whole. The proliferation in such courses in colleges and universities throughout the country has grown in direct proportion to the spread of Women's Movement activities, In part because movemont partioipants are teaching such courses, and, ber 
cause they involve the students in emotional as woll as academic particlpation these courses have an impact on the form of culture change the movement itself hopes to achiove.

The Women's Movement as a social phenomenon has interesting implications for culture change generally because it aims at permanently restructuring the social order, and, whether this restructuring is confined to changing the status of women to share in the same privileges granted to men, or whother it is extended to complete social reform along the lines of socialist ideology, the resultant position will be difforent in oither case.

Mang Women's Liberation participants, including this one, view the existing status of women as a cross-cultural problem (though in varying degrees from one culture to another), and among the oldest of human conditions. That is, the status of women relative to that of men is defined as boing "less than" that of men in most human groups, and certainly in most rumerically speaking. Only among some groups of hunters and gatherers, where status distinctions appear to bo virtually non-existent, does the position of. women seem to be equal to that of mon. 2 However, since the general question of the status of women, or the position of women in terms of the values of any given cultural group has not really been extunsively examined by arthropologists (until very recontly) it is difficult to araluato the true position or women in terms of a society's status system. 
More than a few ethnographers discuss the status of women either in terms relative to men, or in terms of comparisons relative to women in Westorn civilization, where admittedly, the status of women is high (depending again upon a comparison to that of men). 3

Margaret Mead often discusses the fact that regardless of what any given soclety accords tho highest value it usually involves those things which men do and it is usualiy granted to men. 4 It is understanaable, therefore, how status differentiation has grown out of the basic division-of-labor between the sexes. A woman's adult functions aro prescribed at birti, whereas a man's adult functions have to be achieved. Because of women's child-bearing functions and their noed to care for thoir off-spring for long periods of time and becauso of the hunting and warfare activities of men and the value placed on being auccessful hunters and warriors, status differentiations based on asoribod vexsus achieved economic and social functions have resulted in the elevation of males to a higher stacus in most humen groups. 5

Judith Brown's study of the status of women based on the sexual divieion-of alabor shows that in gonoral the work women do will be closely tied to her primary responsiblilties of infant care and child tending. 6 This in turn bears upon her relative value in a society. Studies of women cross-culturally tond to indicate that the greater tho 
woman's oconomic contribution to the group, in addition to her primary function of childboaring, the highor her status is more likely to bo. ${ }^{7}$ All of which indicates that in order for women to have positions of oquality with men in human societies they must achieve on a comparable economic level with men, that fulfilling their primary function alone (that of childbearing and childrearing) is not enough.

At this point, however, women are in a very real "bind" (that is, conflict situstion) for most humen groups (this one included) hold various forms of traditional values which restrict women's activities and thus, they limit their opportunitios to achieve. Typical examples of the kinds of social restrictions placed on women are such cultural customs demanding that women be "ladylike" in public bohavior (and private) as In the United States, 8 chopping of ${ }^{8}$ tho fingers of infant female children as among the Dani of the New Guinea highlands, prohibiting women to $g \circ$ in public unescorted as in Latin American countries and in some Middlo Eastern countries as well, requiring women to be velied as is the custom in some North African countries, and so on. These are vory Eenoral examples, but they sorve to show that oven if individual women in male-dominant cultures (and this includes most human cultures) would wish to change their status relative to men they would faco difficult and, in some cases, seemingly insumountable obstacles.

In addition to the social customs which place physical 
barriers to female equality, women also face numerous psychological/social barriers. A recent observer of such psychological barriers in Western civilization, in particular, noted that:

as long as men define women as economically dependent on and socially indistinguishable from themselves, it is exceedingly difficult for men to perceive the issue of female inequality as a genuinely serious one.9

In addition, the observer said he feit that:

$\therefore$ whlle it is difficult for most white men to take the isslie seriously it appears even more difficult for most black men.10

In the United States, in particular, this is because Black men (in lower socio-economic categories, generally) seo achievement and elimination of racism as being accomplished when they have access to the same rights and privileges that white men have, and when "their" Black women live like white suburban American women, all of which is in sharp contrast to the goals the Women's Liberation Movement hopes to achieve, which is a sharing in any given society's rights and privileges by all of its members regardless of race or sex.11 This means specifically that women have to be recognized as poople in their own right and not as adfuncts to rales, that is, in addition to being for instead of always being) wives, mistresses, and bearers of children, they need to be recognized as statesmen, politicians, explorers, inventors, sdministrators (for some women in the movement), and cultural innovetors. It is obviously true the women do hold 
these kinds of positions, but they need to be able to hold them as a matter of course, not as notable exceptions to the traditionally prescribed positions of women. At least, the are the aims of those seeking oqual rights for women.

It is interesting that the situation of women from a macrocosmic view is, moreover, reflected in a microcosmic sense in this study. That is, the greater tho individual woman's sense of deference to men and the more passive her behavior the greater is her subordination to men. Howevor, women who consciously manifest deference behaviors to men do so as a matter of self-protection. All of the women in this study who acknowledged this continued behavior, in spite of their expressed intellectual rejection of it, pointod out the nature of their economic dependence upon the men they were associated with. The fear of losing this economic support was a basic reason for not wanting to dismupt these relationships.

In some situations fear of physical repression acts as an inhibitor to participation in the Women's Movement. The extreme example of this situation was demonstrated in China In the late 1920 's when the Kuomintang was attempting to repress the forces of the Maost revolution and one of the tactics of repression adopted was to torture and kill women who had been participants in the Maofst version of Women's Liberation, and the death toll was in the thousands.12 (Even after the Maoist revoluition was succossful women who joined 
Women's Liberation groups often faced physical repression at the hands of relatives.)13

If the Women's Liberation Movement were successful it would produce deep-seated changes in the structure of human culture. The Women's Movement, al though most active and extensive in the United States, has its counterparts in a number of European countries, as well as Africa, China, Cuba, and Latin America. However, countries where the discrepancy of status betweon the sexes has traditionally been the greatest (with the exception of China) the Women's Movement is least pronounced, and in most such societies non-existant. Only in the United States and European countries, where the statis of women most closely approximates that of men is tho Women's Movement most operative as a force outside of state polftical control. (In socialist or so-called socialist countries the Women's Movement is a part of the state structure and has different implications for women, although not necessarily for culture change.)

Beceuse the status of women relative to men's is generally similar cross-culturally, and because the Women's. Liberation Vovement is not restricted to Western societies but has its counterparts in non-Western societies as well, the implications of the ideas and goals of the movement touch the lives of people everywhere. And because of these implications the Women's Iiberation Movement as a social phenomenon should be of special interest to social scient- 
ists in general, snà anthropologists, in particular, because,

as Beverly Chiñas pointed out in a recent paper,

anthropology thus far has had so little to contribute to the subject Lof Women's Studies 7 and .... it is very important that we present crosscultural data in teaching about women to a far greater extent than we have boen...

Perhaps the greatest disappointment in searching for cross-cultural data on women is the general absence of specific data in anthropological sources. This lacuna has been remarked from time to time in the profession but until tho most recent past pitifully few anthropologists have been much concerned with women's roles or with women as one-half of the species Homo sapiens. In far too many ethnographies, Including some of the mo st recent unfortunately, women appear as inconspicuous background figures,.wives of men, mothers of children....

The dileina in which anthropology finds itself in regard to sex roles is proving more than a little embarrassing to a profession which has boasted of its holistic and comparative approach to human social systems. Those of us who have become increasingly aware of the extent to which...ethnocentric biages have skewed the interpretation of othnographic data have had our faith in existing data, methodology, and theory severly shaken... Although anthropology probaby can never be completely free from ali bias, certainly wo who teach courses in anthropology or use anthropological data in terching need to be aware of the pitfalls of using existing data uncritically. Through a fuller understanding of tho importance of the roles of both sexes in every socisi system, we should be eble to present a more balaneed and a more accurate view of human society. 14

Finally, the Women's Movement should be of special in-

terest to bumanity because as Adrienne Rich points out:

... what is really "In the air" is not only the politics of housework or new marriage contrects or even, more seriously, equal pay for equal work, but a sense, on the part of men as well as women, that the way we live in a patriarchal society is dangerous for humanity. 15 
FOOTNOTES

GHA PTER VI

${ }^{1}$ See Antta Lynn Micossi, "Convarsion to Women's Lib.," in Transaction, Nov./Doc. 1970, pp.82-90.

2Thers appears to be some evidence of the absence of any status distinctions botween the sexes among the nowlyPound Tasaday's of the Philippines, at least there is an absence of a division-or-labor based on sex. Also, the Pygmies of the Ituri Forest (Africa), especially the nethunters, give evidence of bolng a truig egalitarian group.

${ }^{3}$ See almost any standardethnographic account. Women are being discussed in terms of a culture's value system as to their "proper" function, however the ethnographic accounts focus on men and what men do, and women are dis. cussed usually only in terms of their roles as wives, junior wives, mistresses, adultry, kinship, and marriage customs, all of which are activities relating to thoir aexual and procreative functions. For spectific examples pick up any introductory text to cultural anthropology and examine the listings for women in the index.

4see Margopet Megd's, Male and Female, (Now York: Dell Publishing Co., 1.949), and sex and Temperament, (Now York: Mentor Books, 1950).

5 See Nancy Chodorow's discussion of "ascribed va. achieved" status in "Being and Doing: a Cross-Culturel Examination of the Socialization of Males and Females," in Women in Soxist Society, edited by $V$. Gornick and $B$. Moran (Now York: Basic Books, 1971), pp. 173-197.A1so, an interesting article on the effects of socialization based on "ascribsd va. achleved" is Barry, Bacon, and Child's, "A Cross-Cultural Survey of Somo Sex Differences In Soefa]1zation," Ir AI-Isaa and Dennis's, Cross-Cultural Studies of Bohavior, (New York: Holt, Rinehart and Winston, Inc., 1970), pp. 275-285。

6For a discussion of the division-of-labor and its implications for the status of women seo Judith Brown's "A Note on the Division of Labor by Sex," in Americen Anthropologist 72:5:1073-2078; also, Rathloein Cough's articlo "Tho Origin of the Fanilg" reprinted in Up From Under, 1972, 1:3:47-52. 
7 Chodorow, op. cit., Ruby R. Leavitt, "Women in Other Cultures," in Gornick \& Moran, op. cit., pp. 276-303.

8 Leslie Haines, "Women in Symbolic Protest," Oregon Times, Spetember 1972, pp. 29-31. She demonstrates that being "ladylike" has seriou drawbecks to political activity and in obtaining social equality.

9John Scanzoni, Sexual Bargajning: power politics in the American marriage. (Englowood Clif's, K.J. PrenticeHa11, Inc. 1972), p. 123 .

${ }^{10}$ Ibid.

11 There seems to be some evidence thet upper-class Black families have different values and goals and these are reflected in the heary emphasis they place upon educating daughters, and in the fact that upper-class or upper income Black families are often composed of two professionals, both husband and wife having soparate professions.

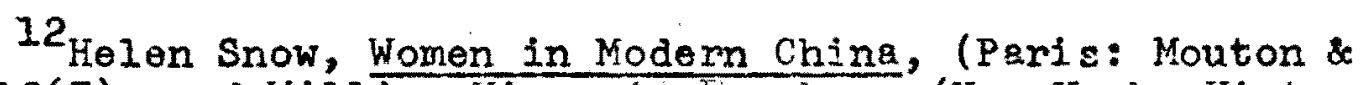
Co., 1967); and William Hinton's Frangheil, (New York: Vintage Books, 1966).

13Hinton, 으. it.

14 Beverly Chiñas, "Toaching About Women Cross-Culturally: a critical appraisal of the anthropological data." Preliminary draft prepared for Workshop on Toaching About Women, for the annual meeting of the National Council on Family Relations, held in Portland, Orogon, Nov, I I.72. (Dept, of Anth., Calif. State Univ., Chico, Calif.)

15Adrienne Rich, "The Anti-Faminist woman," in The New York Review of Books, Nov. $30,1972, \mathrm{p} .34$. 


\section{A LIST OF WORKS CONSULTED}

Adams, Elale, and Briscoe, Mary Louise (eds.). Up Against the Wall, Mother... Beverly Hills, Calif. Glencoe Press, 1971.

Adelstein, Michael E., and Plwal, Joan G. (eds.). Women's Liberation, New York: St. Martin's Press, $1 \overline{972 .}$

Ahlum, Carol, and Howe, Florence (ode.). The Now Guide to Current Fomale Studies. Pittsburgh, Pa.: Inow, Inc., 1971.

Allen, Pamela. The Small Group Process. San Francisco: Sudsoflopper, $196 \%$.

Al-Issa, Ihsan, and Dennis, Wayno (eds.). Cross-Cultural Studies of Behavior. New York: Holt, Rinehart, \& Winston, 1970 .

Amundsen, Kirsten. The Sllenced Majority. Finglewood Cliffa, N.J.: Prentice-ilall, 1971.

Anders, Carol. Sox and Caste in Anerica. Englewcod Ciiffs, N.J.: Prentice-Ha11, 1971.

Anderson, Jack. "President Nixon and the Womon," Parade, The Oregonian, October 31, 1971 .

Bardwick, Judith $K$. Psychology of Women: a Study of B10Cultural Conflicts. Now York: Harper \& Row, 1971.

Barnett, Homer. Innovation: the Basis of Cultural Change. Now York: McGraw-hill, 1953.

Beard, Mary R. Woman as Force in History. New York: Collier Books, 1962 .

Bobol, August. Women Under Soctalism: Studes in the lif'e of Women. Reprinted from the New York Labor Press, 1904, New York: Schocken Books, 1971.

Becker, H. S., and Strauss, A. L., "Careors Personality, and Adult Socialization," Americen Journal of Sociologe, LXII (November 1956), pp. 253-263. 
Bem, Sandra L., and Bem, Daryl J. "Training the Woman to Know Her Place: the Power of a Non-conscious Ideology," in Garskof (ed.), Roles Women Pleg: Readings Toward Women's Liberation. Belmont, Calif.: Brooks/Cole Co. 1971, pp. 84-96.

Bird, Caroline. Born Female. New York: Pocket Books, 1961.

Boston Women's Health Course Collective. Our Bodies Our Selves. Boston: New England Free Press, 1971.

Breasted, Mary. "Move Over 'Cosmo, Here Comes 'Ms.' $f$ " Saturday Review, July 15, 1972, pp. 5-12.

Brown, Judith $K$. "A Note on the Division of Labor by Sex," American Anthropologist, 72:5:1073-1078.

Burkhart, Kitsi. "Women in Prison," Ramparts. June 9, 1971, pp. 21-29.

Cade, Toni (ed.). The Black Women. New York: New Amerjcan Library, 1971.

Chmaj; Betty (ed.). American Women and American studies. ( A text prepared for the American Studies fosociation Commission on the Status of Women), Pittsburgh, Pa.: Know, Inc., 1971.

Cudlipp, Edytho. Understanding Women's Liberation. New York: Paperback Library, 1971.

Culligan, Glendy. "Born Free But Not Liberated," Saturday Revies, June 5, 1971, pp. 25-4.1.

De Beauvoir, Simono. The Second Sox. Now York: Bantam Books, 1952.

DeCrow, Karen. The Young Woman's Guide to Liberation. Ind tanapolis, Ind.: The Bobbs-Merrili Co., 1971.

Dixon, Marlene. "Why Women's Liberation?" Detroit, Michigan: Radical Education Project Reprints, 1969.

- "A Position Paper on Radica? Women in the Profession: or Up From Radical." Chicago, I1l.: New University Conference, 1969.

Dixon, Marlene, at al. Iiberation Now: Writings From the Women's Liberation Novement. Wob York: Dell Publighing Co., 197L. 
Eliman, Mary. Thinking About Women. New York: Harcourt Brace Jovanovich, Inc., 1968.

Epstein, Cynthia Fuchs. Women's Place. Berkeley, Calif.: Unlversity of Califomia Press, 1971.

Epstein, Cynthia Fuchs, and Goode, William J. (eds.). The Other Half: Rogds to Women's Fquality. Englewood. Cliffs, N. J.: Prentice-hall, Inc., 1971.

Erikson, E. H. "The Problem of Ego Identity," Psycholog1Cal Issues: Identity and the Life Cycle, 1:101-66.

Farber, Seymour M., and Wilson, Roger H. L. (eds.). The Potential of Woman. San Francisco: McGraw-Hili, 1963.

F1ges, Eva. Patriarchal Attitudes: The Case for Women in Revolt. Greenwich, Conn.: Fawcett Fublications, Inc., 1970 .

Firestore, Shulamith. The Dialectic of Sex. New York: Bantam Books, 1970 .

Flexner, Elegnor. Century of Struggle. New York: A theneuri, 1970.

Friedan, Betty. The Feminine Mystique. New York: Dell Publishing Co., 1963.

Garskof, Michele Hof frung (ed.). Roles Women Play: Readines Toward Women's Liberation. Belmont, Calir.: Brooks/Cole, 1971.

Gilman, Charlotte Perkins. Women and Economics. Edited by Carl N. Degler. New York: Harper \& Row, Publishers, 1966. (First publishad in 1898: Bostan: Maynarc \& Company.)

Girson, Rochelle. "What Did the Nineteenth Amendrient Amend?" Saturday Review, October 11, 1969, p. 29.

Goldunan, Emma. The Traffic in Women: and Other Essays on Feminism. New York: Times Change Press, 1970. (First published in 1917: Now York: Mothor Earth Publishing Association.)

Goode, W. J. "A Theory of Role Strain," American Sociological. Review, VoJ. 25, No. 4 (August, 1960), 483-96. 
Goodenough, Ward Hunt. Coopergtion in Change. New York: Russell Sage Foundation, 1963.

Gornick, Vivian, and Moran, Berpara K. (eds.). Woman in Sexiet Scciety. New York: Basic Books, 1971.

Gough, Kethleen. "Review of Kate Millet's Sexurl Politics," Monthly Review, 1972, 22:47-56.

- "The Origin of the Family," Reprinted in Un From Under, $1972,1: 3: 47-52$.

Graham, Patricia A. "Women in Acrdeme," Science, Sept. $23,1970,3.69: 1248-1290$.

Greer, Germaine, The Female Eunuch. New York: McGrawHill, $1970-71$.

Griffin, Susan. "Rape: the all-American Crime," Famparts, Sept., 1971, pp.26-35.

Gutstein, Linda. "Worien Comics: Why They Try Harder," Paxade, The Oregonian, November 21, 1971 .

Haines, Loslia. "Women in Symbolic Protest," Oregor Times, Sept., 1972, pp.29-31.

Hampton, Jim. "The Compleat Revolution: Restructure Every Thing, New Forinists Demand," The National Observer, March 9, 1970, p. 1 .

Hardin, Garrett. Population, Evolution, and Birth Control. San Francisco: W. H. Froeman \& Co., 1964.

Heilbrun, Carolyn. "The Masculine Wilderness of the Americśn Novel," Saturàa Review, January 29, 1972, pp. $41-44$.

Hinckle, Warren and Marianne. "Woman Power," Ramparts, Fobruary, 1970, pp.22-31.

Hinton, Williaks. Fanshen. New York: Vintage Books, 1966.

Howe, Floronce (ed.). Fomalo Studies II. Pitisburgh, Pa.: Know, Inc., 1970.

Howe, Florence, ard Ahlum, Carol (eds.). Fsmale Studies III. Pittsburgn, Pa.: Know, Inc., 1971. 
Hughes, Merijo Matich. The Sexual Barrier: Legal and Eronomic Aspocts of Enploymont. A bibliography prepared for Hastings College of tho Law Library. San Francisco: Univorsity of Colif.: Hastings, 1970.

Janoway, Elizebeth. "Ihe Subordinate Sox," Saturday Review, Octobor 11, 1971, pp. 27-57.

Jordan, Joan. "Protective Laws," Dotroit, Michigan: Radical Education Reprints, 1970.

Kanowitz, Leo. Women ard the Lew. Albuquerque, New Mexico: University of hew Mcxico Press, 1969.

Kollonta1, Alexandra. Women Workers Struggle for Their Rights. Translated from the Russian by Celia Britton. Montpelier, Bristol, England: Friling Wall Press, 1971.

Komarorsky, Mirra. "Cultural Contradictions and Sex Roles," American Jourasi of Sociology, Nov, 1946, 52:3:184-89.

Kraditor, Aileen (ed.). Up From the Podastal. Chicago, Ill: Quadrangle Books, 1970.

Lader, Lawrence. Abortion. Boston: Eeacion Press, 1966. Lemer, Gerda. The Grimke Sisters. New York: Schociken
Books, 197 .

Letter from Seattle women. "Seattle Liberation Front," The Mole, Boston: November 20, 1.970, pp. 19-20.

Leviathan. "Women Unite." May 2, 1970, entire issue. - "Women's Liberation." June 1, 1969.

Eife. "The iWoman Problem' - Then and Now." Feature article. August 13, 1971, pp. 40-55.

Iifton, Robert Jay (ed.). The Woman in America. Boston: Beacon Press, 1964.

Lund, Garoline. "Women's Strike, August 26," The Militant, Septomior 11, 1970, pp. 9-11.

Malbin, Nona, Glazer, and Waerer, Helen. Woman in a ManMade World. Chic8go: Rand MicNally, 1972.

McAfree, Kathy, and Wood, Myrna. "Broad and Roses," Detrott, Michlgan: Radical Education Project Reprints, 1969. 
McClollard, David C. "Wanted: a New Self-Image for women," The Voman in America. Edited by R. J. Lifton. Boston: Beacon Press, 1964, 173-192.

Mead, Margarot. Sex and Temperament in Throe Primitive Socletles. New York: The New American Library, 1935.

- Male and Female. Now York: Dell Publishing Co., $194 \overline{9}$.

Micossi, Anita Lynn. "Conversion to Women's Lib.," Transaction, Nov./Doc. 1970, 82-90.

Mill, John Stuart. "The Subjection of Women," Reprinted 1971. Cambridge, Mass.: The MIT Presso (First publishod in 1869.)

Millett, Kate. Sexual Polities. Garden City, New York: Doubleday \& Co., 1970 .

Mitchell, Juliet. "The Longest Revolution," New Left Review, November/December 1966.

- Woman's Estiate. New York: Panthoon Books, 1971.

Montague, Ashley. The Natural Superiority of Wornen. New York: Collier, 1952.

Morgan, Robin (ed.) Sisterhood is Powerful. Now Yolk: Vintage Books, 1970.

Myrdal, Alva, and Klein, Viol2. Women's Two Roles. London: Routlodge \& Kegan Paul Ltd., 1956.

Myrdal, Gunnar. An American Dilemma: Appendix V. New York: Harper \& Row, I944.

Now University Conference. "I Am Furious, Female," Detroit, Michigan: Radical Education Project Reprints, 1968.

Newsweek. "Women in Revolt. Who's Who in Women's Lib, and How Critics View the Movement," Speciel Report. March 22, 1970.

O'Neil.l, William. The Woman Movement: reminism in the United States and England. Chicago: Quadrangle Books, 1969,

Painter, Edith. "Women: the Last of the Diseriminatedi" Journal of the National Association of Women Deans and Counselors, (winter, 1971) 34:2:59-62. 
Parsone, Talcott. Nhe Position of Identity in the General Theory of Action," in The Self in Social Interaction.

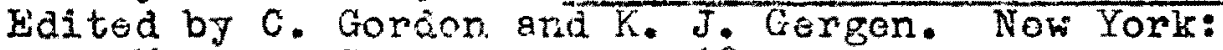
John Wiley \& Sons, Ine., 1968, 1:11-23.

Peterson, Esther. "Status of Women in U.S.," Internationa1 Labour Review, (1964), 89:447-460.

Rawalt, Margaerite. "Itigating Sex Discrimination Caeos," Family Law Querterly, (1970), 5:44-52.

Rich, Adrienne. "The Anti-Feminist Woman," The New York Review of Books, November 30, 1972, 34-40.

Robins, Jcan. Handbook of Women's Liberation. Edited by Roger Lovin. Worth Hollywood, Calif.: Now Library Press, 1970.

Rogers, Agnes. Women are Here to Stay. New York: Harper Bros., 1949.

Rossi, Alice. "Women in Science: Why so Fow?" Science, (May 28, 1965), 14:8:1196-1202.

- "Discrirination and Demography Restrict Opportunities for Academic Women," College and University Business, (February, 1970), 74-78.

- "Sisterhood is Beautiful," Psychology Today, August, $1972,40-75$.

Roszak, Theodore, and Roszak Betty. (eds.). Masculine/ Feminine. New York: Harper \& Kow, Publishers, 1969.

Rowntree, Mickey, and Rowntreo, Jchn. "More on the Political Economy of Women's Liberation," Monthly Roview, (1970), 21:26-32.

Safilios-Rothschlld, Constantina (ed.). Toward a Sociology of Women. Loxington, Mass.: Xerox College Publishine, 1972 .

Sandier, Bernice. "The Equal Rights for Women Amendment," Reprinted from statement made before the Senate Judiciary Comittes SubComittee on Constitutional Amendmonts, May 6, 1970. Pittsburgh, Pa.: Know, Inc., 1972 .

Scanzoni, John. Sexual Bargaining: Power Polities in tire American marriago. Englowood Cliffs, N. J.: PrenticeHaII, Inc., 1972. 
Schulder, Diane. "Women and the Las," Atlantic Monthly, (March, 1970), 225:103-104.

Shah, Diane K. "Our Angry Wornor: They're Getting Together to Challenge the System," The National Observer, May 17, 1971, 10:20:1.

Showalter, Elaine, and Ahlum, Carol (eds.). Female Studies IV. Pittsburgh, Pa.: Know, Inc., 1971.

Simon, Kita. "The Woman Ph.D. a Recent Profilo," Social Problems, (Fall, 1967), 15:2:221-236.

Smuts, Robart W. Women and Work in Amarice, New York: Schocken Books, 1971.

Snow, Helen Foster. Women in Modern China. The Hague, Par1s: Mouton \& Co., 1967.

Sontag, Susan. "The Douile Standard of Aging," Saturdey Review, Septembar 23, 1972, 29-38.

Stambler, Sookle (ed.). Women's Liberation: Blueprint for the Future. New York: Ace Books, 1970.

Stoin, Leonard I. "Male and Female: the Doctor-Nurse Game," Conflict and Conformity: Roadings in Cultural Anthropology. Edited by J. P. Soradley and $D_{*} W_{\text {. McCuräy. }}$ Boston: Little, Brown \& Co., 1971, 185-193.

Stone, Betsy. "Sisterhood is Powerful," A Morit Pamphlet. New York: Pathfinder Press, Inc., 1970.

Sullerot, Evelyne. Woman, Soclety and Change. New York: McGraw-Hill, 1971.

Swidlor, Loonard. "Jesus Was a Feminist," Catholic World, January, $1.971,177-183$.

Tanner, Leslie B. (ed.). Volces From Homen's Liberation. Now York: Signet Books, 1970.

Tobias, Sheila (od.). Female Studies I. Pittsburgh, Pa.: Know, Ine., 2970.

The Wa]l Street Journal. "Lot Goorge Do It." Feature article, Augus t 4, 1970.

The Vom an Question. New York: International Publishons, 1951. Selections trom Marx, Engas, Stalin. 
Thompson, Mary Lou (od.). Votces of the New Feminism. Boston: Beacon Press, 1970.

Time. "The Politics of Sex," Feature article, August 31, 1970 .

- "The American Woman," Feature issue, March 20, 1972.

Irensection, "The Astan koman," Foature issue, November/Docember 1970.

Trotsky, Loon. "Women and the Family," A Merit Pamphlet. Reprinted fror a 1924 article. New York: Pathrinder Press, Inc., 1970.

U. S. Dept. of Lahor. Women's Bureau Bulletins. Waghington, D. C.: Government Printing office.

Vidal, Gore. "In Another Country," The New York Rgview of Books, July 22, $1971,8-12$.

Ware, Cellestine. Woman Power: The Moverent for Women's Liberation. New York: A Tower Public Affairs Book, 1970.

Westervelt, Esther M., Fixter, Deborah A., and Comstock, Margaret. Women's Higher and Continuing Education: an Annotated Bibliography with Selected References on Related Aspects of Women's Lives. New York: College intrance Examination Board, 1971.

Williams, Maxine, and Newman, Pamola. "Black Women's Iiberation," A Nerit Pamphlet. New York: Pathfinder Press, Inc., 1970.

Willis, Fllen. "Consumerism and Women," Socialist Revolution. 1:3. (May/Juno 1970).

"The Fartasy of the Perfect Lovor," The New York Revien of Books. Auguat 31, 1972, 7 m8.

SOME WOHEN'S PERIODICALS CONSULTED

Alliance Link. (Chicago, Ill.) 1970-1971.

Aphra. (New York) 1970-1971.

BlEck Maria. (River Forest, III.) 1972. 
Evergwomen. (Los Angeles, Calif.) 1971.

Female Liberation. (Berkeley, Calif.) 1970-1971.

Hurnan Rights for Women Wowsletter. (Washington, D. C.) 1971.

It Ain't Me Babe. (Albany, Calif。) 1971.

Notes From the Second Year. (New York) $19 \% 0$.

Notes From the Third Year. (New York) 1971.

Ms. (New York) 1972.

No More Fun and Games. (Cambridge, Mass.) 1971.

Off Our Backs. (Washington, D. C.) 1971.

Third World Women's Alliance. (New York) 1971.

The Women Activist. (Falls Church, Va.) 1970-1971.

Triple Jeopardy. (New York). 1971-1972.

Up From Under. (New York). 1970-1972.

Women: A Journal of Liberation. (Baltimore, Ma.) 1970-1972.

Women's Press, (Eugene, Oregon). 1971. 
APPENDIX

SURVEY QUESTIONAIRE CODING

Some 160 junior college and university students were asked to respond to these questions: 1) What do you perceive the goals of Women's Ifberation to be? 2) What are your personal reactions to the Women's Liberation Movement? They were also asked to incluae thoir sex, age, marital status, work status (whether they were working, and if so, full or part-time), and the educational level of their parents. From the responses it was possible to categorize their perceived goals and their personal resctions as follows:

\section{Perceived Goals}

A Economic equality

B Social Equality

C Rellove oppressed status

D Unisex-destroy feminity

E Destroy the family

F Child care centers

$G$ Fulfill potential.

H Elinination of treatment as a sox object
Personal Reactions

$X$ Agree on goals-not on methods

1 Agree on economic goals

2 Agree on social goals

3 Agree on "oppression"

4 Disagree on all goals

5 Movement is a joke

6 God made us as we are

7 Goals too radical

8 Women want equality but not responsibility

9 Women are frail

Responsos were listed in order of frequency, statistical information vas coded similarly, and information was then systematized. Following is a sample of the coding results. No. SEX AGE Marital Worix Parent's Educ. Per. Goals Personal Status M. F. Reactions

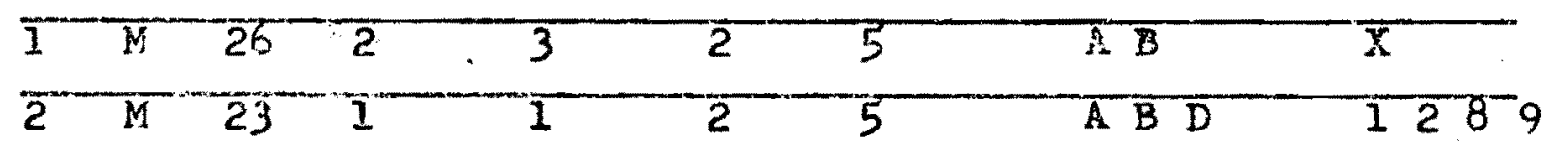




\section{TNTERVIEW SCHEDULE}

A. How did you happen to get involved in the Women's Liberation Movement?

1. What particular experience or set of experiences led to your participation?

2.. What does Women's Liberation mean to you?

B. Have changes occurred in your life since becoming a participant?

1. How do you see your involvement in terms of:

a. kinds of commitment (and justification)?

b. understanding of what neods to be changed (if anything)?

co resultant changes in persorial behavior (o.g., does being a participant allow you to do things you couldn't do in the past.)

2. Has self-reappraisal been part of your experience with Women's Liberation activities?

a. In what aress?

b. Do the things you do surprise you or affect your past image of yourself?

c. How do you feel about sharing your experiences in Women's Liberation?

1. Are you interested in getting other women to participate?

2. What about explaining to men? 
D. How is your participation accepted by others?

1. In your home situation?

2. On the job?

3. In your personal relations?

4. With old friends?

5. What is the acceptance of others generally?

E. Are you satisfiad with the Women's Liberation Movement?

1. With its' goals (as you perceivo them)?

2. With your own understanding of the movement?

3. With your participation level?

F. Whose recognition of your particlpation means the most to you?

1. What specific individual?

2. What is their rolationship to you?

3. Why is this person's recognition importent?

G. How do you see yourself now?

1. In terms of behavior?

2. In terms of how you present yourself as a women? 